INGRID AQUINO AMORIM

\title{
ANÁLISE DE PEPTÍDEOS DE DEFESA DO HOSPEDEIRO NA OSTEOCLASTOGÊNESE MEDIADA POR RANKL IN VITRO
}




\author{
UNIVERSIDADE DE BRASÍLIA \\ FACULDADE DE CIÊNCIAS DA SAÚDE \\ PROGRAMA DE PÓS-GRADUAÇÃO EM CIÊNCIAS DA SAÚDE
}

INGRID AQUINO AMORIM

ANÁLISE DE PEPTÍDEOS DE DEFESA DO HOSPEDEIRO NA OSTEOCLASTOGÊNESE MEDIADA POR RANKL IN VITRO

Dissertação apresentada como requisito parcial para a obtenção do Título de Mestre em Ciências da Saúde pelo Programa de Pós-graduação em Ciências da Saúde da Universidade de Brasília.

Orientadora: Prof. ${ }^{a}$ Dr. ${ }^{\text {a }}$ Taia Maria Berto Rezende

Coorientador: Prof. Dr. Octávio Luiz Franco

BRASÍLIA 
INGRID AQUINO AMORIM

\title{
ANÁLISE DE PEPTÍDEOS DE DEFESA DO HOSPEDEIRO NA OSTEOCLASTOGÊNESE MEDIADA POR RANKL IN VITRO
}

\begin{abstract}
Dissertação apresentada como requisito parcial para a obtenção do Título de Mestre em Ciências da Saúde pelo Programa de Pós-graduação em Ciências da Saúde da Universidade de Brasília.
\end{abstract}

Aprovado em 27 de Julho de 2016

\section{BANCA EXAMINADORA}

\author{
Prof $\stackrel{a}{\text {. Drạ }}$. Taia Maria Berto Rezende (Presidente) \\ Universidade de Brasília (UnB)
}

Prof ${ }^{\text {. }}$. Dra ${ }^{\mathrm{a}}$. Anne Carolina Eleutério Leite

Universidade Católica de Brasília (UCB)

Prof. Dr. Laudimar Alves de Oliveira Universidade de Brasília (UnB) 
À minha família querida, que sempre me amparou nas difíceis escolhas e indecisões, em especial à minha mãe Francisca Eridam, aos meus irmãos, Lucas e Isabela, e à minha tia e madrinha Elixandra, pelo apoio emocional e financeiro de sempre. Sem vocês eu não seria capaz. Amo-os de alma e de coração. 


\section{AGRADECIMENTOS}

À Deus, em primeiro lugar, que sabe todas as coisas, e sempre me deu forças para nunca desistir.

Ao Programa de Pós-graduação em Ciências da Saúde, da Universidade de Brasília, pela oportunidade acadêmica no stricto sensu.

À minha orientadora Prof ${ }^{\underline{a}}$ Dr $^{\underline{a}}$ Taia Maria Berto Rezende, pelos ensinamentos, dedicação, competência e confiança, mesmo sabendo da minha falta de experiência laboratorial, acreditou em mim. Obrigada por tudo!

Ao meu coorientador Prof. Dr. Octávio Luiz Franco, um grande incentivador e idealizador de grandes e importantes pesquisas científicas, pela oportunidade, apoio e confiança de sempre.

À Prof ${ }^{a}$. Drạ. Evelyn Mikaela Kogawa, pela compreensão, pelos ensinamentos e pela parceria, que desde a iniciação científica na graduação, incentivou-me a apresentar nossos trabalhos em congressos, buscar o conhecimento e continuar as pesquisas no mestrado. Muito obrigada por tudo isso, sem você não teria chegado tão longe!

Aos membros da banca examinadora Prof. Dr. Laudimar Alves de Oliveira, pela disponibilidade e boa vontade em participar como membro da banca. Aos Professores queridos, Prof. Dr. Eric Jacomino Franco e Prof ${ }^{a}$. Dr ${ }^{\mathrm{a}}$. Anne Carolina Eleutério Leite, pelos ensinamentos da periodontia desde a graduação; vocês foram os maiores responsáveis pela paixão que hoje sinto por esta área da odontologia, além de serem grandes exemplos de humildade, profissionalismo e competência. Agradeço imensamente pelo acolhimento no estágio docente do mestrado.

Ao meu amado namorado, o doutorando Fabrício Reichert Barin, pelo apoio e paciência, especialmente nesse período final do Mestrado. Sem você tudo seria mais difícil! E à sua família querida, Geovani, Nilsa e Geovana, mesmo de longe sempre me deram força e incentivo para chegar até aqui. Em especial minha sogra Nilsa Reichert Barin, pela revisão de linguagem.

À minha querida amiga, a doutoranda Ana Paula de Castro Cantuária, pelo companheirismo de sempre; mesmo sem me conhecer direito no início, ensinou-me 
a dar os primeiros passos na sala de cultura e me acompanhou nas disciplinas do mestrado, boa parte do que sei, devo a você. Conte comigo pra tudo!

Às amigas doutorandas Mirna de Souza Freire, pela sabedoria, paciência e ensinamentos sobre "o mundo dos osteoclastos", e Stella Maris de Freitas Lima, pelos ensinamentos, ajudas e disponibilidade de sempre, além da colaboração nas figuras desse trabalho. Vocês são feras!

À querida amiga de todas as horas, MSc. Flávia Rodrigues Pereira Dutra, pela paciência, broncas necessárias, pela disponibilidade; estava sempre pronta para ajudar, em especial, pelo auxílio na purificação da LL-37.

Ao Prof. Dr. Jeeser Alves de Almeida, pela compreensão e auxílio nas estatísticas deste trabalho.

Ao doutorando Nelson Gomes de Oliveira Júnior, pela amizade e pela ajuda de sempre, principalmente pela checagem da pureza dos peptídeos no MALDI.

Aos alunos de iniciação científica André Cruz, Monalisa Morais, Mayara Oliveira, Danilo Martins, Tarsila Figueiredo, Jade Ormondes e Tássio Fernandes, que de alguma forma acompanharam-me e me ajudaram muito.

Aos mestrandos Elaine Lôbo, Poliana Silva e Maurício de Sousa, pela ajuda e companheirismo.

À doutoranda Camila Guimarães, pela ajuda e pelas ótimas sugestões.

À técnica Kênia Carneiro, pelos conselhos, ajuda e pronta disponibilidade.

À toda equipe da Universidade Católica de Brasília (UCB) e da Universidade de Brasília (UnB); professores e funcionários, pelo suporte e dedicação.

Ao Centro de Análises Proteômicas e Bioquímicas (CAPB) e à Universidade Católica de Brasília (UCB) pela estrutura e parceria constante.

À Coordenação de Aperfeiçoamento de Pessoal de Nível Superior (CAPES), Conselho Nacional de Desenvolvimento Científico e Tecnológico (CNPq), Universidade Católica de Brasília (UCB), Universidade de Brasília (UnB) e Fundação de Apoio à Pesquisa do Distrito Federal (FAPDF), pelo apoio financeiro. 
"O sucesso é ir de fracasso em fracasso sem perder entusiasmo".

(Winston Churchill) 


\section{RESUMO}

A remodelação óssea representa um processo de suma importância no sistema esquelético humano. Entretanto, um desequilíbrio na função ou ativação excessiva de osteoclastos pode resultar em extensas reabsorções ósseas. Nesse contexto, peptídeos de defesa do hospedeiro (PDHs) podem apresentar um potencial no desenvolvimento de novas terapias. Nessa perspectiva, o presente estudo avaliou o efeito dos peptídeos clavanina A, clavanina MO e LL-37, na supressão da osteoclastogênese in vitro mediada pelo ligante do receptor de ativação do fator nuclear kappa $B$ (RANKL). Estes resultados foram comparados com medicações utilizadas clinicamente, hidróxido de cálcio P.A. e doxiciclina, em terapias endodônticas e periodontais, respectivamente. Os parâmetros analisados em culturas da linhagem celular RAW 264.7, com ou sem recombinante (r) RANKL, PDHs e controles clínicos, foram: (1) viabilidade celular pelo método de MTT; (2) produção de óxido nítrico (NO); e número de osteoclastos diferenciados, após coloração de fosfatase ácida tartarato resistente (TRAP). Os resultados demonstraram que os PDHs e os controles clínicos não foram citotóxicos às células, exceto na presença de $128 \mu \mathrm{g} \cdot \mathrm{mL}^{-1}$ de doxiciclina após $72 \mathrm{~h}$, na presença e ausência de rRANKL, que apresentou redução de cerca de $50 \%$ da viabilidade celular. A produção de NO foi mantida estável ou reduzida na presença de todas as concentrações dos PDHs e controles clínicos, comparados ao grupo controle, na ausência de rRANKL. Como esperado, a presença de rRANKL elevou sutilmente os níveis da produção de NO. No entanto, a presença dos PDHs e controles clínicos permitiram ora estabilidade, ora redução dos níveis de NO, quando comparados ao grupo controle, exceto na presença de $2 \mu \mathrm{g} \cdot \mathrm{mL}^{-1}$ de doxiciclina após 7 dias, que promoveu aumento significativo na produção de NO. Na osteoclastogênese, todos os PDHs e controles clínicos foram capazes de reduzir a diferenciação de osteoclastos. Em conclusão, os PDHs podem atuar como potenciais supressores da osteoclastogênese in vitro. Dessa forma, o uso dos PDHs se apresenta como uma forma terapêutica promissora para 0 tratamento de reabsorções ósseas perirradiculares e periodontais.

Palavras-chave: osteoclastogênese; RANKL; RAW 264.7; peptídeos de defesa do hospedeiro. 
ABSTRACT

Bone remodeling is an important process in the human skeletal system. Nevertheless, an imbalance in the osteoclast function or its excessive activation, may result in extensive bone resorption. In this context, host defense peptides (HDPs) may have a potential for novel therapies development. This study evaluated the potential of HDPs clavanin A, clavanin MO and LL-37 in down-regulate in vitro receptor activator of nuclear factor kappa $B$ ligand (RANKL)-mediated osteoclastogenesis. HDPs results were compared to currently available medications for endodontic and periodontal therapies, calcium hydroxide P.A. and doxycycline, respectively. The parameters analyzed in cell line RAW 264.7 cultures stimulated with or without recombinant ( $r$ ) RANKL and HDPs and clinical controls were: (1) cell viability by MTT method; (2) nitric oxide production (NO); and (3) number of differentiated osteoclasts, after tartrate-resistant acid phosphatase (TRAP) staining. Results showed that HDPs and clinical controls were not cytotoxic, except in the presence of $128 \mu \mathrm{g} \cdot \mathrm{mL}^{-1}$ of doxycycline after $72 \mathrm{~h}$, in the presence and absence of rRANKL, which decreased about $50 \%$ the cell viability. The NO production was kept stable or reduced in the presence of all concentrations of HDPs and clinical controls, compared to the control group, in the absence of rRANKL. Otherwise, the presence of rRANKL subtly up-regulated the NO production levels. However, the presence of HDPs and clinical controls remained stable or reduced the NO production compared to the control group, except in the presence of $2 \mu \mathrm{g} \cdot \mathrm{mL}^{-1}$ of doxycycline after 7 days, which up-regulated NO production. During the osteoclastogenesis process, all HDPs and clinical controls were capable of reducing the osteoclasts differentiation. In conclusion, host defense peptides can act as potential suppressors of in vitro osteoclastogenesis. Thus, HDPs represent promising drugs for periradicular and periodontal bone resorption treatments.

Keywords: osteoclastogenesis; RANKL; RAW 264.7; host defense peptides. 


\section{LISTA DE FIGURAS}

Figura 1- Linhagem de pré-osteoclastos RAW 264.7, divididos em 2 grupos: Grupo controle 1, linhagem de pré-osteoclastos RAW 264.7; Subgrupos - células RAW 264.7 com a adição de clavanina A, clavanina MO, LL-37, $\mathrm{Ca}(\mathrm{OH})_{2}$ e doxiciclina. Grupo controle 2, células RAW 264.7 estimuladas com o rRANKL; Subgrupos células RAW 264.7 estimuladas com o rRANKL, com a adição de clavanina A, clavanina $\mathrm{MO}$, LL-37, $\mathrm{Ca}(\mathrm{OH})_{2}$ e doxiciclina .52

Figura 2: Citotoxicidade dos peptídeos clavanina A (A), clavanina MO (B), LL-37 (C) e controles clínicos $\mathrm{Ca}(\mathrm{OH})_{2}$ (D) e doxiciclina (E) a 2, 8, 32, e $128 \mu \mathrm{g} \cdot \mathrm{mL}^{-1}$ em $2,5 \times 10^{3}$ células RAW 264.7 por poço, após $72 \mathrm{~h}$ e $7 \mathrm{~d}$, por ensaio MTT. O grupo controle foi constituído de $2,5 \times 10^{3}$ células RAW 264.7 por poço. A viabilidade celular foi representada por média e o erro padrão, na absorbância de $595 \mathrm{~nm}$, realizado em triplicata técnica e biológica. * $\mathrm{p}<0,05$ comparando-se ao grupo controle, em cada condição testada. op<0,05 comparando-se aos grupos contendo $128 \mu \mathrm{g} \cdot \mathrm{mL}^{-1} \mathrm{de}$ cada produto, em cada condição testada. \#p<0,05 comparando-se aos grupos contendo $32 \mu \mathrm{g} \cdot \mathrm{mL}^{-1}$ de cada produto, em cada condição testada.

Figura 3: Citotoxicidade dos peptídeos cavanina A (A), clavanina MO (B), LL-37 (C) e controles clínicos $\mathrm{Ca}(\mathrm{OH})_{2}$ (D) e doxiciclina (E) a 2, 8, 32, e $128 \mu \mathrm{g} \cdot \mathrm{mL}^{-1}$ em

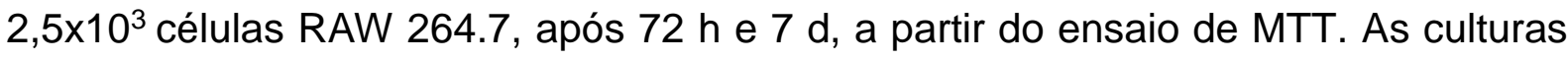
foram estimuladas com 100ng. $\mathrm{mL}^{-1}$ de rRANKL. O grupo controle consistiu de $2,5 \times 10^{3}$ células RAW 264.7 estimuladas com 100 ng. $\mathrm{mL}^{-1}$ de rRANKL. A viabilidade celular foi representada por média e erro padrão, na absorbância a 595 nm, realizada em triplicata técnica e biológica. ${ }^{*} \mathrm{p}<0,05$ comparando-se ao grupo controle, em cada condição testada. op<0,05 comparando-se aos grupos contendo $128 \mu \mathrm{g} \cdot \mathrm{mL}^{-1}$ de cada produto, em cada condição testada. \#p<0,05 comparando-se aos grupos contendo $32 \mu \mathrm{g} \cdot \mathrm{mL}^{-1}$ de cada produto, em cada condição testada. $\square \mathrm{p}<0,05$ comparando-se aos grupos contendo $8 \mu \mathrm{g} \cdot \mathrm{mL}^{-1}$ de cada produto, em cada condição testada .62 
Figura 4: Produção de óxido nítrico na presença dos peptídeos clavanina $A(A)$, clavanina MO (B), LL-37 (C) e controles clínicos $\mathrm{Ca}(\mathrm{OH})_{2}$ (D) e doxiciclina (E) na

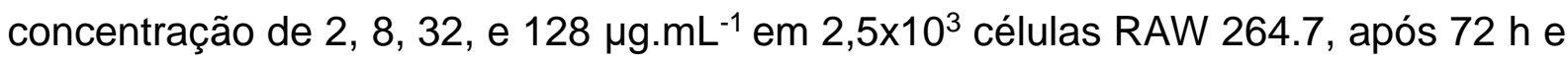
$7 \mathrm{~d}$, pelo método de Green et al., com adaptações. O grupo controle foi constituído de $2,5 \times 10^{3}$ células RAW 264.7 por poço. As barras representam média e erro padrão, na absorbância a $490 \mathrm{~nm}$, realizadas em triplicata técnica e biológica. ${ }^{*} \mathrm{p}<0,05$ comparando-se ao grupo controle, em cada condição testada. $o p<0,05$ comparando-se aos grupos contendo $128 \mu \mathrm{g} \cdot \mathrm{mL}^{-1}$ de cada produto, em cada condição testada. \#p<0,05 comparando-se aos grupos contendo $32 \mu \mathrm{g} \cdot \mathrm{mL}^{-1}$ de cada produto, em cada condição testada. $\square \mathrm{p}<0,05$ comparando-se aos grupos contendo $8 \mu \mathrm{g} \cdot \mathrm{mL}^{-1}$ de cada produto, em cada condição testada.

Figura 5: Produção de óxido nítrico na presença dos peptídeos clavanina $A(A)$, clavanina MO (B), LL-37 (C) e controles clínicos $\mathrm{Ca}(\mathrm{OH})_{2}$ (D) e doxiciclina (E) na

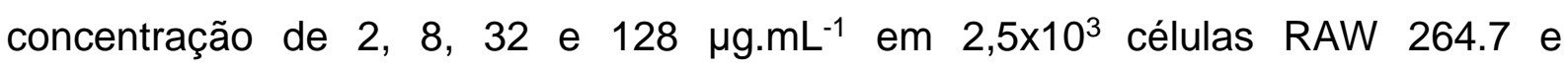
estimuladas com 100 ng.mL ${ }^{-1}$ of rRANKL por poço, após $72 \mathrm{~h}$ e $7 \mathrm{~d}$, através do

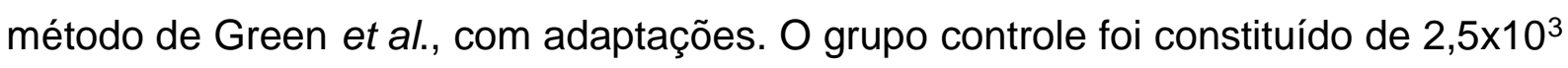
células RAW 264.7 por poço, estimuladas com $100 \mathrm{ng} \cdot \mathrm{mL}^{-1}$ de rRANKL. As barras representam média e erro padrão, na absorbância de $490 \mathrm{~nm}$, realizadas em triplicata técnica e biológica. ${ }^{*} p<0,05$ comparando-se ao grupo controle, em cada condição testada. op<0,05 comparando-se aos grupos contendo $128 \mu \mathrm{g} \cdot \mathrm{mL}^{-1}$ de cada produto, em cada condição testada. \#p<0,05 comparando-se aos grupos contendo $32 \mu \mathrm{g} \cdot \mathrm{mL}^{-1}$ de cada produto, em cada condição testada. $\square p<0,05$ comparando-se aos grupos contendo $8 \mu \mathrm{g} \cdot \mathrm{mL}^{-1}$ de cada produto, em cada condição testada. .66

Figura 6: Culturas celulares representadas por fotografias após a coloração de TRAP de cada concentração testada, após 7 d de cultura. O primeiro grupo controle foi constituído de $2,5 \times 10^{3}$ células RAW 264.7 por poço (A); o segundo grupo controle, constituído de $2,5 \times 10^{3}$ células RAW 264.7 por poço, estimuladas com 100 ng. $\mathrm{mL}^{-1}$ de rRANKL (B). Perfil das células RAW 264.7 (2,5 $\times 10^{3}$ por poço), estimuladas com 100 ng. $\mathrm{mL}^{-1}$ de rRANKL na presença de clavanina $A(C)$, clavanina MO (D), LL-37 (E) e controles clínicos $\mathrm{Ca}(\mathrm{OH})_{2}(\mathrm{~F})$ e doxiciclina $(\mathrm{G})$ na concentração de 2, 8, 32, e $128 \mu \mathrm{g} \cdot \mathrm{mL}^{-1}$ (respectivamente indicado nas colunas). 
Figura 7: Número de osteoclastos diferenciados na presença de clavanina $A(A)$, clavanina MO (B), LL-37 (C) e controles clínicos $\mathrm{Ca}(\mathrm{OH})_{2}(\mathrm{D})$ e doxiciclina (E) nas

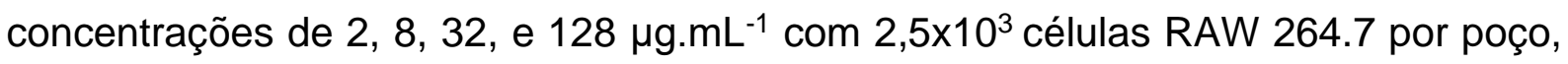
estimuladas com $100 \mathrm{ng} \cdot \mathrm{mL}^{-1}$ de rRANKL, após $7 \mathrm{~d}$ de incubação, seguido de

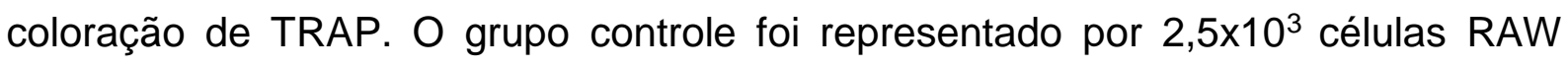
264.7 por poço estimuladas com 100 ng. $\mathrm{mL}^{-1}$ de rRANKL. O número de osteoclastos foi representado por média e erro padrão, realizados em triplicata técnica e biológica. ${ }^{*} p<0,05$ comparando-se ao grupo controle, em cada condição testada. op $<0,05$ comparando-se aos grupos contendo $128 \mu \mathrm{g} \cdot \mathrm{mL}^{-1}$ de cada produto, em cada condição testada. $\# p<0,05$ comparando-se aos grupos contendo $32 \mu \mathrm{g} \cdot \mathrm{mL}^{-1}$ de cada produto, em cada condição testada. $\square \mathrm{p}<0,05$ comparando-se aos grupos contendo $8 \mu \mathrm{g} \cdot \mathrm{mL}^{-1}$ de cada produto, em cada condição testada. .69

Figura 8: Concentração de $8 \mu \mathrm{g} \cdot \mathrm{mL}^{-1}$ dos peptídeos clavanina A, clavanina MO e LL-

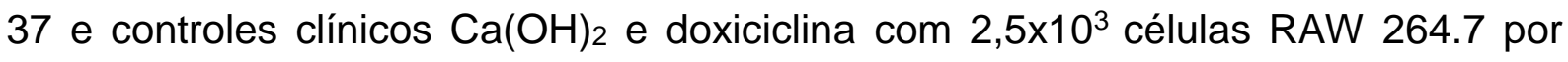
poço, estimuladas com $100 \mathrm{ng} \cdot \mathrm{mL}^{-1}$ de rRANKL, após $7 \mathrm{~d}$ de incubação, seguido de coloração de TRAP. O número de osteoclastos foi representado por média e erro padrão, realizados em triplicata técnica e biológica. ${ }^{*} p<0,0001$ comparando-se à clavanina $\mathrm{A}$, em cada grupo testado. op<0,0001 comparando-se à clavanina $\mathrm{MO}$ em cada grupo testado. $\# p<0,0001$ comparando-se à doxiciclina em cada grupo testado. 71

Anexo 1: Espectros obtidos por MALDI-TOF, dos peptídeos de defesa do hospedeiro Clavanina A, Clananina MO e LL-37. .98 


\section{LISTA DE TABELAS}

Tabela 1. Sequência e massa molecular dos peptídeos clavanina $A$, clavanina $\mathrm{MO}$ e

LL-37. .55 


\section{LISTA DE ABREVIATURAS E SIGLAS}

$\mathrm{Ca}(\mathrm{OH})_{2}$ - hidróxido de cálcio

CATK - catepsina $\mathrm{K}$

c-Fos - fator de transcrição de grande importância para a osteoclastogênese

DMEM - Dulbecco's Modified Eagle's Medium

DMSO - dimetilsufóxido

EDTA - ácido etilenodiamino tetra-acético

EGF - fator de crescimento epidérmico

eNOS - óxido nítrico sintetase endotelial

Er:YAG -érbio: yttriumaluminum-garnet

FPR2 - peptídeo formil 2

hCAP18 - peptídeo antimicrobiano catiônico humano 18

HDL - lipoproteína de alta densidade

$\mathrm{H}_{2} \mathrm{O}_{2}$ - peróxido de hidrogênio

IFN-Y - interferon gama

IL - interleucina

iNOS - óxido nítrico sintetase indutível

L929 - fibroblastos de camundongos

LPS - lipopolissacarídeo

MALDI-ToF - Matrix Assisted Laser Desorption Ionization - Time of Flight

MAPK - proteína quinase ativada por mitógeno

MCP - proteína quimiotática de monócitos

M-CSF - fator estimulador de colônias de macrófagos

MMPs - metaloproteinases de matriz

MTT - 3-(4,5-dimetiltiazol-2yl)-2,5-difenil brometo de tetrazolina

M1 - macrófago tipo 1

M2 - macrófago tipo 2

$\mathrm{NaOCl}$ - hipoclorito de sódio

NFATc1 - fator nuclear das células T ativadas c1

NF-kB - fator nuclear kappa B

nNOS - óxido nítrico sintase neuronal

NO - óxido nítrico 
NOS - óxido nítrico sintase

$\mathrm{Nd}$ :YAG - neodímio: yttriumaluminum-garnet

OPG - osteoprotegerina

PAMs - peptídeos antimicrobianos

PDHs - peptídeos de defesa do hospedeiro

PMCC - paramonoclorofenol canforado

RANK - receptor de ativação do fator nuclear kappa B

RANKL - ligante do receptor de ativação do fator nuclear kappa B

RAW - linhagem celular de monócitos/macrófagos de tumor induzido da leucemia murina de Abelson

rRANKL - recombinante RANKL

RT-HPLC - cromatografia líquida de alta eficiência em fase reversa

TGF- $\beta$ - fator de transformação do crescimento beta

Th1 - linfócitos T helper tipo 1

Th2 - linfócitos T helper tipo 2

Th17 - linfócitos T helper tipo 17

TIMPs - inibidor tecidual de metaloproteinases

TNF- $\alpha$ - fator de necrose tumoral alfa

TRAF 6 - fator associado ao receptor TNF 6

TRAP - fosfatase ácida tartarato resistente

Treg - célula T regulatória 
1 INTRODUÇÃO

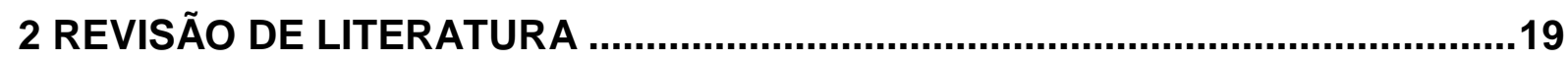

2.1 OSTEOCLASTOS E REABSORÇÃO ÓSSEA …......................................19

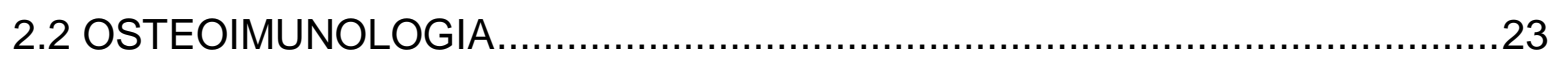

2.2.1 Óxido Nítrico ............................................................................30

2.3 TRATAMENTO DAS PATOLOGIAS ENDODÔNTICAS E PERIODONTAIS

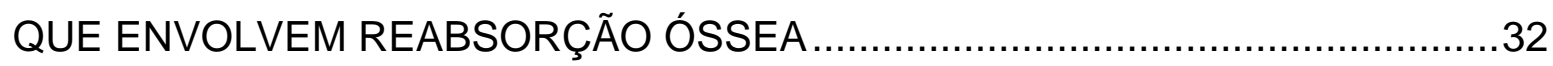

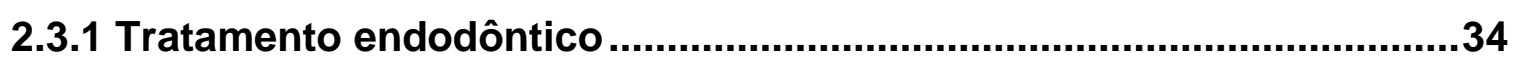

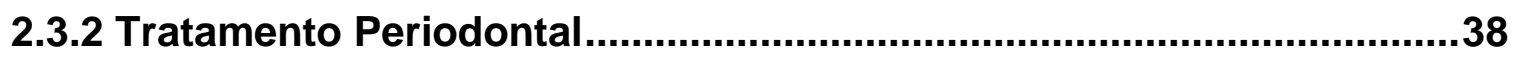

2.4 PEPTÍDEOS DE DEFESA DO HOSPEDEIRO ........................................40

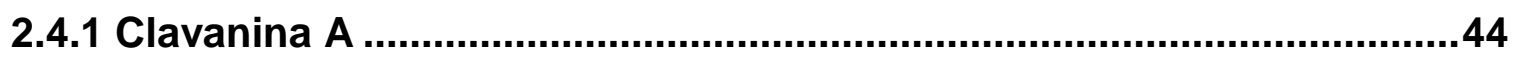

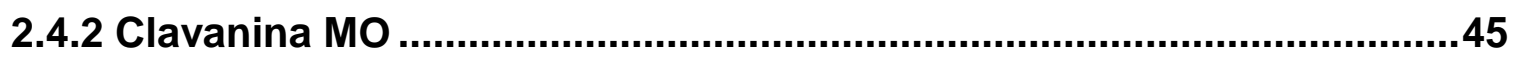

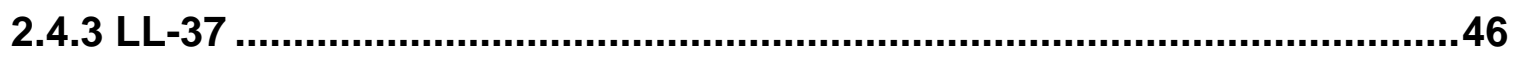

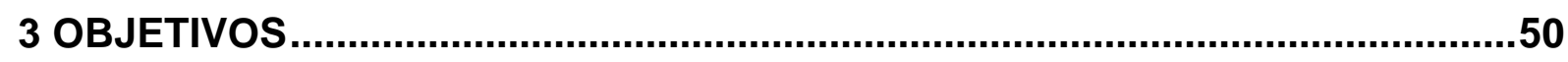

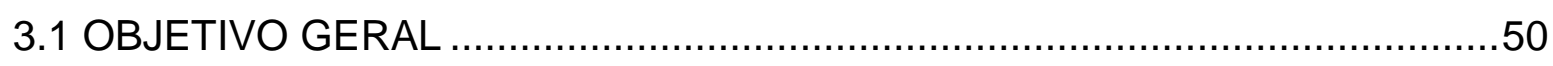

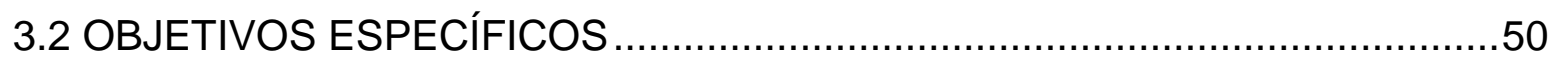

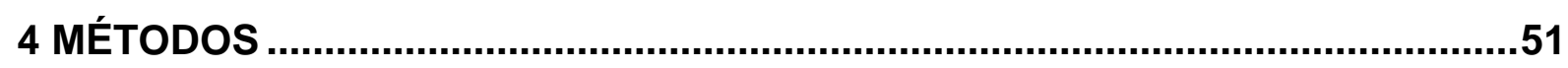

4.1 CARACTERIZAÇÃO DO ESTUDO

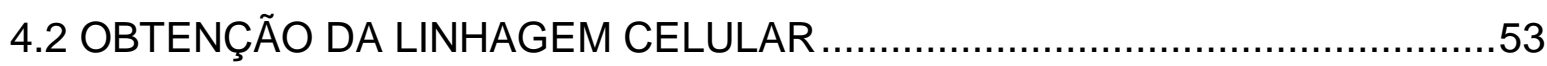

4.3 SÍNTESE E PURIFICAÇÃO DOS PEPTÍDEOS CLAVANINA A, CLAVANINA

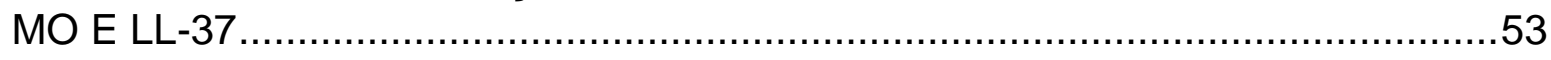

4.4 OBTENÇÃO DO HIDRÓXIDO DE CÁLCIO E DA DOXICICLINA .....................55

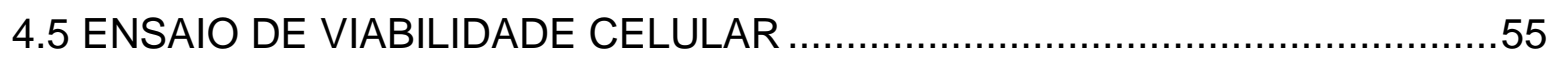

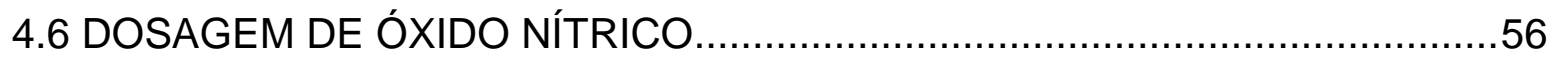

4.7 OSTEOCLASTOGÊNESE E COLORAÇÃO DE FOSFATASE ÁCIDA

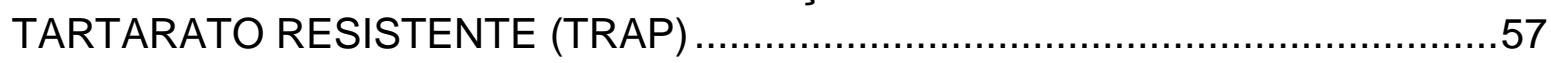

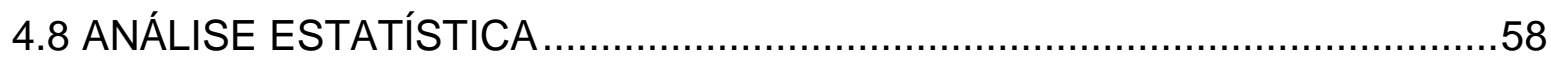

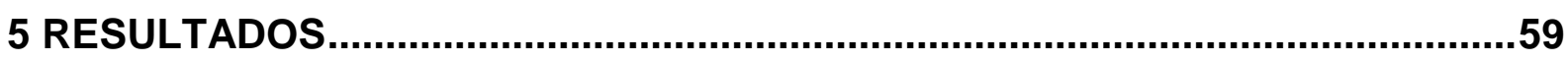

5.1 VIABILIDADE CELULAR EM DIFERENTES CONCENTRAÇÕES DE PEPTÍDEOS E CONTROLES CLÍNICOS

5.2 PRODUÇÃO DE ÓXIDO NÍTRICO EM DIFERENTES CONCENTRAÇÕES DE PEPTÍDEOS E CONTROLES CLÍNICOS 
5.3 OSTEOCLASTOGÊNESE MEDIADA POR rRANKL EM DIFERENTES CONCENTRAÇÕES DE PEPTÍDEOS E CONTROLES CLÍNICOS

5.4 ANÁLISE COMPARATIVA DA MENOR CONCENTRAÇÃO COMUM ENTRE OS PEPTIIDEOS E OS CONTROLES CAPAZ DE REDUZIR A OSTEOCLASTOGÊNESE .70

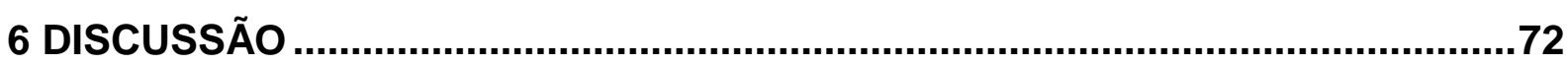

7 CONCLUSÃO

REFERÊNCIAS BIBLIOGRÁFICAS..........................................................85

ANEXOS

Anexo 1: Espectros obtidos por MALDI-TOF, dos peptídeos de defesa do hospedeiro Clavanina A, Clananina MO e LL-37. .98 


\section{INTRODUÇÃO}

A remodelação óssea consiste em um processo natural de suma importância. Entretanto, quando há um desequilíbrio na função ou na ativação excessiva de osteoclastos, podem gerar-se extensas reabsorções ósseas como as presentes em doenças ósseas sistêmicas e intrabucais, ao exemplo de lesões perirradiculares e da doença periodontal $(1,2)$. O tratamento endodôntico consiste na remoção do conteúdo séptico necrótico da polpa dentária, preparo químico e mecânico além da utilização de medicação intracanal, possibilitando a redução da infecção (3). Já o tratamento da doença periodontal, baseia-se na eliminação das bactérias presentes, principalmente por meio de debridamento mecânico do biofilme dentário (cirúrgico ou não cirúrgico), podendo ser combinado à terapia antibiótica, especialmente em casos de periodontite refratária (4). No entanto, apesar do grande índice de sucesso, tais terapias ainda podem apresentar falhas em casos específicos, principalmente no que tange à capacidade das medicações existentes, de combater efetivamente microrganismos resistentes, e a possibilidade de o indivíduo responder de forma efetiva a esses tratamentos propostos.

Assim, faz-se necessária a busca por novas terapias que ofereçam novos benefícios, além dos já propostos nas medicações utilizadas atualmente. Neste sentido, os peptídeos de defesa do hospedeiro (PDHs) são apresentados como nova proposta para o desenvolvimento de medicações intracanais e adjuvantes das terapias mecânicas periodontais, devido sua provável atividade imunomodulatória e antimicrobiana, que pode se apresentar por meio de diferentes mecanismos, com probabilidade, assim, de dificultar a resistência destes microrganismos $(5,6)$.

Diante de resultados obtidos previamente, sugeriu-se a capacidade imunomodulatória e redução do processo de osteoclastogênese, na presença dos peptídeos clavanina A, clavanina MO e LL-37 (7), por meio de análises in vitro. No entanto, são escassas as informações na literatura de referência em relação a redução da osteoclatogênese a partir dessas biomoléculas. Portanto, este trabalho visou à avaliação do potencial dos peptídeos clavanina A, clavanina MO e LL-37, comparados às medicações disponíveis atualmente, hidróxido de cálcio P.A. e doxiciclina, na supressão da osteoclastogênese in vitro mediada pelo rRANKL. Além 
disso, objetivou-se, nesta pesquisa, a determinação do potencial de uso dessas biomoléculas no tratamento de lesões endodônticas e da doença periodontal. 


\section{REVISÃO DE LITERATURA}

\subsection{OSTEOCLASTOS E REABSORÇÃO ÓSSEA}

Com a finalidade de manter o sistema esquelético saudável em estrutura e função, a remodelação óssea se torna um processo constante e de suma importância ao longo da vida, diante do equilíbrio entre a reabsorção óssea realizada por osteoclastos e a formação óssea por meio dos osteoblastos. No entanto, um desequilíbrio patológico nesses processos celulares pode resultar em reabsorções ósseas extensas (8). Esse tipo de reabsorção pode ser constituída por duas etapas incluindo a osteoclastogênese, que consiste na diferenciação da célula préosteoclástica (monócito/macrófago) em osteoclasto multinucleado e a ativação dos osteoclastos (9). Os osteoclastos consistem em células altamente especializadas, derivadas de uma linhagem hematopoiética monócito/macrófago, cujo desenvolvimento pode ser regulado por osteoblastos (8). Os osteoblastos por sua vez, podem ser derivados de células estaminais mesenquimais, e após a formação óssea podem sofrer apoptose. Logo, os osteoblastos podem tornar-se células de revestimento ósseo ou podem cercar-se de matriz extracelular. Assim, os osteoblastos, depois de mineralizados, podem tornar-se osteócitos e podem ser incorporados à matriz óssea mineralizada (8). A porção mineralizada da matriz extracelular pode ser composta em grande parte por fosfato de cálcio na forma de hidroxiapatita, acrescida de um extensivo colágeno tipo I, rico em matriz extracelular orgânica (8).

Os monócitos/macrófagos podem se diferenciar em osteoclastos multinucleados. A diferenciação pode ocorrer pela ação do fator de estimulação de colônias de macrófagos (M-CSF) e pelo ligante do receptor de ativação do fator nuclear kappa B (RANKL) (10), uma proteína produzida por osteoblastos, células do estroma ósseo e linfócitos T e B ativados (9) e fibroblastos gengivais. Nesse sentido, citocinas, como a interleucina-1 (IL-1), IL-6 e fator de necrose tumoral (TNF)- $\alpha$, podem aumentar a atividade dos osteoclastos. A IL-6 pode ser produzida por osteoblastos que, direta ou indiretamente (pelo estímulo da produção de RANKL) ativam esses osteoclastos (11). O RANKL e a osteoprotegerina (OPG) estão entre 
as proteínas mais conhecidas e envolvidas na regulação da homeostase óssea. $\mathrm{O}$ RANKL pode ligar-se ao receptor de ativação do fator nuclear kappa B (RANK) e dessa forma, conduzir à ativação dos osteoclastos, culminando na reabsorção óssea. A OPG, proteína também produzida por osteoblastos (11) representa um outro receptor para RANKL (12), e dessa maneira pode inibir a ligação de RANKL com RANK, impedindo assim a maturação do osteoclasto e, consequentemente, a perda de massa óssea (11). Nesse caso, RANKL, o seu receptor RANK e o inibidor natural OPG, podem ser essenciais para o desenvolvimento, regulação e ativação desses osteoclastos (13).

A partir da ligação RANK / RANKL, em geral, há o recrutamento do fator associado ao receptor TNF 6 (TRAF6), que pode levar à ativação de outras vias de sinalização intracelulares, tais como o fator nuclear kappa B (NF-kB) e a proteína quinase ativada por mitógeno (MAPK). Tais cascatas de sinalização podem culminar na indução de um componente da família de proteínas AP-1, o c-Fos, que é um fator de transcrição de grande importância para a osteoclastogênese. A expressão do fator nuclear das células T ativadas c1 (NFATc1), um outro fator importante para a expressão de genes específicos de osteoclastos, pode ser então induzida por cFos e NF-kB (10).

Nesses termos, a qualidade óssea compreende várias características como a geometria óssea, microarquitetura, a qualidade do material da matriz extracelular óssea, entre outros (14). A remodelação disfuncional pode resultar em condições patológicas tais como a osteoporose ou osteosclerose (8). Dentre elas, a osteoporose pode ser caracterizada pela redução da massa óssea, alterações na microarquitetura do tecido ósseo, resistência óssea reduzida e um aumento do risco à fratura, apresentando-se como a doença óssea metabólica mais comum, que pode afetar até $30 \%$ das mulheres e $12 \%$ dos homens em algum momento da vida. Nesse sentido, as terapias atuais para essa patologia buscam a supressão da reabsorção óssea (15). Portanto, níveis instáveis das proteínas OPG e RANKL, além das citocinas envolvidas na formação e reabsorção óssea, também estão associados a doenças como artrite reumatoide, osteoporose, doença de Paget, osteopretrose, tumores ósseos, lesões osteolíticas faciais, doença periodontal e lesão perirradicular (9).

Para compreender melhor tais fenômenos, são importantes estudos in vitro e in vivo que mimetizem essas condições. Nesse contexto, RAW 264.7 pode ser uma 
importante linhagem celular de monócitos/macrófagos precursora de osteoclastos. A célula RAW 264.7 pode facilmente diferenciar-se em osteoclastos quando estimulados pelo RANKL. A linhagem RAW 264.7 ainda pode ser capaz de produzir seu próprio fator estimulador de colônia de macrófagos (M-CSF) (16). Assim, tais fatores recrutam células multinucleadas levando-as a se aderirem ao osso e, posteriormente, a se diferenciarem em osteoclastos maduros. Após isso, os osteoclastos podem ser induzidos a secretar prótons e enzimas líticas no vacúolo de reabsorção, entre eles e a superfície óssea (17). Por outro lado, os monócitos removidos da medula óssea, diferentemente das células RAW 264.7, precisam, além do RANKL, o M-CSF exógeno (18). A linhagem de monócitos/macrófagos RAW 264.7 pode ser induzida a se diferenciar na linhagem osteoclástica na presença do recombinante (r) RANKL na concentração de 100 ng.mL-1 (19).

Nessa perspectiva, a ativação dos receptores presentes na superfície das células precursoras de osteoclastos pode resultar na regulação da expressão de uma variedade de genes. Nesse processo podem ser incluídos os genes que codificam a fosfatase ácida tartarato resistente (TRAP), catepsina $K$, e integrina $\alpha_{v} \beta_{3}$ que podem gerar o osteoclasto (20). Além disso, podem ser responsáveis pela degradação das matrizes de colágeno e degradação de osso mineral. Diante disso, os osteoclastos podem ser ativados mediante efeito de acidificação, pela secreção de prótons (17). Dessa forma, algumas informações gênicas podem ser responsáveis por reorganizar várias funções celulares como a adesão celular, a dinâmica do citoesqueleto, a polaridade celular e o transporte de membranas durante a diferenciação dos osteoclastos. Para degradar o osso, os osteoclastos se aderem à superfície óssea, polarizam e criam um alto e especializado domínio de membrana, que se agita sob a superfície do osso, formando uma lacuna de reabsorção (20). Por meio dessas atividades, a reabsorção óssea pode estar envolvida em diversas patologias ósseas sistêmicas e locais, cujas doenças, podem acometer os tecidos de suporte dos dentes; por isso, é necessária uma melhor compreensão acerca desse tema.

Nesse contexto, muitas doenças sistêmicas e específicas da região oral, resultam no comprometimento dos tecidos de suporte dos dentes, acarretando perda da massa óssea e, consequentemente, dos elementos dentários. Dentre elas, destacam-se doenças como osteomielite, osteonecrose, osteossarcomas, osteítes, tumores odontogênicos, reabsorções provenientes de movimentação ortodôntica 
inadequada, periimplantites, entre outras. Com maior frequência, ainda se observam reabsorções ósseas oriundas de lesões perirradiclares e doença periodontal, as quais são tema deste estudo.

As reabsorções ósseas perirradiculares e periodontais, destacam-se por apresentarem maior frequência na odontologia. Essas reabsorções podem ser impulsionadas por meio da permanência de microrganismos e da manutenção de uma resposta imune adaptativa na área pulpar, periapical e periodontal, podendo gerar uma resposta exacerbada, que pode culminar no início da reabsorção óssea periodontal e perirradicular, com chance, ainda, de perpetuar-se a partir de eventos osteoimunológicos (21). Nesse sentido, as citocinas relacionadas com as células $T$ helper (Th) 17 vêm sendo relacionadas à patogênese da periodontite, devido à sua capacidade de induzir a osteoclastogênese (22). Por apresentarem semelhanças, tais citocinas são também de interesse na periimplantite, devido ao possível aumento dos níveis de IL-17 em pacientes com ela diagnosticados (23).

Nessa perspectiva, as lesões perirradiculares podem ser induzidas pela infecção crônica da polpa dental e antígenos microbianos que estimulam a resposta imune não específica e específica em tecidos periapicais. Como consequência desses processos e em resposta à incapacidade dos mecanismos de defesa do hospedeiro para erradicar a infecção, lesões perirradiculares crônicas podem ser formadas objetivando a restrição da invasão microbiana (24). Assim, a resposta imune patológica a estímulos de canais radiculares infectados pode resultar no desenvolvimento de lesões inflamatórias perirradiculares causadas por infecção multimicrobiana não específica (1). Dessa forma, tal resposta inflamatória pode levar à reabsorção óssea progressiva na região perirradicular. Isso pode ocorrer por indução das células imunes, como macrófagos e linfócitos $T$, que podem iniciar esse processo por meio da liberação de citocinas pró-reabsorção, na região adjacente à área de saída das bactérias pelo canal radicular (forame apical) (25).

Em outro contexto, a doença periodontal consiste em uma patologia que afeta grande parte da população e envolve a estrutura de suporte dos dentes (26). A doença periodontal apresenta-se como uma condição progressiva que pode resultar na destruição do osso alveolar e ligamento periodontal, que mantêm os dentes no alvéolo dos ossos da maxila e mandíbula, eventualmente culminando na perda dentária $(27,28)$. Em adição, a periodontite é considerada uma doença imunoinflamatória crônica que resulta da interação entre um biofilme complexo e 
mecanismos imunológicos de proteção, que também pode progredir para a destruição dos tecidos de suporte. Assim, o resultado da extensão da perda óssea alveolar se torna dependente da resposta do hospedeiro estimulada pela infecção bacteriana $(2,29)$. A periodontite pode envolver interações entre fatores de microrganismos e susceptibilidade do hospedeiro. Diante disso, as citocinas e o LPS presentes nas bactérias podem ativar os macrófagos e estimular a produção de citocinas como a IL-1 e o TNF, que podem ativar os fibroblastos presentes nos tecidos periodontais a produzirem as metaloproteinases de matriz (MMPs). Dessa forma, a produção prolongada e exacerbada de MMPs pelo estímulo de bactérias pode gerar a degradação aumentada do colágeno em indivíduos susceptíveis à doença periodontal. O colágeno, por sua vez, representa um dos principais elementos de suporte e da matriz periodontal. As MMPs, podem ainda, facilitar a reabsorção óssea por meio da degradação da matriz colagenosa do osso após sua desmineralização pelos osteoclastos (30). Atualmente, o papel do sistema imune frente à interação do sistema RANK/RANKL/OPG e às citocinas envolvidas nesse processo têm sido alvo de questionamentos. Nesses termos, a osteoimunologia, que explica a relação entre as células do sistema imunológico e as do sistema esquelético, na ativação da reabsorção óssea, tem gerado avanços na compreensão desses mecanismos, que podem permitir melhores propostas de tratamento de doenças ósseas sistêmicas e de origem odontológica (29).

\subsection{OSTEOIMUNOLOGIA}

A relação entre o sistema imunológico e o esquelético vem sendo estudada desde o início da década de 1970 (31-33). Dessa forma, para descrever a interação entre essas duas áreas, foi criado o termo osteoimunologia $(34,35)$. Compreende-se que as células do sistema imune e as células hematopoiéticas podem ser originadas da medula óssea, sendo propícia a comunicação entre esses dois sistemas $(28,36)$. Diversos grupos de pesquisa investigam como o sistema imune afeta a reabsorção óssea basal e patológica por meio dos osteoclastos. Porém, descobertas recentes sugerem que o alcance da resposta imune adaptativa estende-se à regulação da formação óssea pelos osteoblastos (37). Dessa maneira, o sistema imune tem sido considerado um dos mais importantes reguladores do metabolismo ósseo e sua 
desregulação culmina em doenças ósseas, como a osteoporose pós-menopausa e a perda óssea relacionada à reação inflamatória, como a artrite reumatoide (38).

A compreensão do papel dos linfócitos na biologia óssea, bem como as moléculas envolvidas no sistema osteoimune, tem sido essencial para 0 desenvolvimento de terapias específicas para doenças ósseas (36). Alguns fatores secretados por células do sistema imune também podem ser conhecidos por serem ativadores de osteoclastos (36), como o RANKL secretado por células T e B depois de ativadas, enquanto o receptor RANK pode ser expresso em monócitos e macrófagos (39). Experimentos iniciais com macrófagos identificaram 2 tipos de macrófagos específicos; macrófagos $\mathrm{M} 1$, com atividades pró-inflamatórias clássicas e macrófagos M2, com função no reparo tecidual e na cura de feridas. Estímulos pró-inflamatórios clássicos em resposta ao LPS podem incluir TNF- $\alpha$, IL-6 e IL-1 $\beta$ que, por sua vez, pode contribuir para a inflamação do tecido e a osteoclastogênese. Nesse sentido, os macrófagos M2 normalmente produzem o fator de transformação do crescimento beta (TGF- $\beta$ ) e arginase, fatores comumente implicados nos processos de reparo tecidual (40).

Embora o papel das células do sistema imunológico na manutenção da fisiologia óssea ainda não esteja completamente compreendido, acredita-se que algumas células T possam ter um papel protetor contra a remodelação óssea (36). Estudos in vitro sugerem que as células T CD8+ inibem a osteoclastogênese (36). Em adição, estudos em células $B$ de camundongos deficientes de células $T$ têm destacado o papel desses linfócitos na homeostase óssea. Por outro lado, camundongos deficientes de células B apresentaram osteopenia devido a um aumento da reabsorção óssea. Observou-se ainda que a deficiência de células $B$ apresenta déficit de OPG, demonstrando que as células B podem ser importante fonte de OPG no microambiente ósseo (41).

Apesar de os linfócitos não estarem diretamente presentes na remodelação, conforme atestam teorias relacionadas ao tema, podem desempenhar um importante papel na homeostase óssea, por meio da secreção de fatores protetores inerentes ao microambiente ósseo (36). Esse fato pode ser de extrema importância na patogênese da artrite reumatoide, pois há crença de que o RANKL seja responsável pela perda de massa óssea, por ligar-se diretamente ao osso por meio do sistema imunológico (39). Nesse sentido, alguns estudos de relevância para a artrite reumatoide, identificaram células gigantes semelhantes a osteoclastos na 
interface entre as membranas sinoviais de articulações e o osso. Outros estudos demonstraram que o fluido sinovial continha células precursoras de osteoclastos e células de suporte para a osteoclastogênese, confirmando a presença de osteoclastos em articulações reumatoides, que representam possíveis responsáveis pela destruição óssea. O RANKL também pode ser altamente expresso por células T e por células sinoviais de pacientes com artrite reumatoide. Outras citocinas inflamatórias, como IL-1, IL-6 e TNF, estão presentes no fluido sinovial e podem ser capazes de induzir a expressão de RANKL (36).

Historicamente, as células $\mathrm{T}$ auxiliares têm sido classificadas em dois subconjuntos T helper 1 (Th1) e T helper 2 (Th2). As células Th1 podem diferenciarse em resposta à IL-12, produzida por células dendríticas e podem secretar elevados níveis de interferon gama (IFN-y); as células Th2 podem produzir principalmente IL-4 e IL-13 (39). As células Th17, em contrapartida, foram identificadas como o único subconjunto de células $\mathrm{T}$ helper que podem participar na formação de osteoclastos (39). Como característica, as células Th 17 podem produzir a IL-17 e o IFN-y em baixas quantidades, podendo ainda expressar elevados níveis de RANKL, desencadeando uma inflamação local $(36,39)$. No entanto, sua capacidade foi apenas moderada na indução da formação de osteoclastos in vitro. Recentemente, foi demonstrado que células Th17 derivadas de células $T$, que expressam o fator de transcrição Foxp3 (células exFoxp3), podem ser os indutores mais potentes da formação de osteoclastos entre todas as células T. A conversão de Foxp3+ em células Th17 pode ser impulsionada pela IL-6, que pode ser produzida por fibroblastos sinoviais (39). Na odontologia, o papel dessas células e de citocinas se destacam na perda óssea, que ocorre especialmente na doença periodontal (28) e em infecções de origem endodôntica, que culminam em lesões perirradiculares.

Nessa perspectiva, é importante lembrar que processos infecciosos da polpa dentária podem ocorrer por trauma (42), e principalmente, por lesões de cárie, e sua progressão pode ser motivada pela virulência e proliferação dos microrganismos (21). Tais microrganismos podem iniciar uma resposta imunitária na polpa dentária, caracterizada pela inflamação neurogênica e por muita dor (43), resultando na necessidade de tratamento endodôntico. Constantemente, ocorrem falhas nesse tipo de tratamento, que podem ser devido à presença e persistência de microrganismos patogênicos resistentes aos processos de desinfecção do sistema de canais 
radiculares. Esses agentes patogênicos podem iniciar ou manter um processo imunoinflamatório que leva à reabsorção óssea local (21). Além disso, é importante mencionar que a polpa dentária é localizada entre paredes rígidas de dentina, e necessita de um suprimento vascular colateral, por meio do forame periapical. Quando o sistema vascular pulpar não está mais apto às suas funções, a infecção pulpar possivelmente progride à necrose pulpar total (42).

Inicialmente, a resposta imune periapical localiza a infecção dentro dos limites do sistema de canais radiculares e tenta impedir a sua disseminação sistêmica. No processo de resposta imune do hospedeiro, os neutrófilos normalmente são a primeira linha de defesa após a invasão de patógenos, seguidos dos monócitos (42). A ativação de macrófagos pode estar relacionada com funções microbicidas, secreção de citocinas, recrutamento de células imunes e fagocitose de microrganismos e/ou a liberação de metabólitos tóxicos, além do IFN-ץ que pode ativar macrófagos mesmo sem estímulos microbianos.

Existem indícios de uma possível indução de destruição óssea por meio da ativação da função de osteoclastos por citocinas produzidas por células imunocompetentes em lesões perirradiculares (44). Uma rede de citocinas pode ser ativada no desenvolvimento de lesões periapicais, tais como a IL-1 $\alpha, I L-1 \beta$, TNF- $\alpha$ e IL-6, e que podem elevar a inflamação, estimular a reabsorção óssea pelos osteoclastos e inibir a formação óssea. Entre elas, a IL-1 pode ser a mediadora central da rede, devido a sua expressão estar intimamente associada à gravidade da perda óssea periapical. Atualmente, sabe-se que a atividade dos osteoclastos pode ser mediada por estas citocinas, em parte, devido à capacidade desses mediadores em induzir a expressão de RANKL por osteócitos, osteoblastos, células do estroma, linfócitos e fibroblastos (42).

O TNF- $\alpha$ consiste em uma citocina comumente pró-algésica nos tecidos. A expressão do TNF- $\alpha$ não só pode promover a inflamação, como também pode levar à hipersensibilidade e dor em nociceptores. Com a ligação estabelecida entre TNF- $\alpha$ e dor inflamatória, foi possível identificar sua maior expressão nos dentes dos pacientes afetados com cárie e pulpite (45). Em geral, a expressão e a ação de mediadores pró-inflamatórios podem ser modulados da rede de citocinas reguladoras imunes Th1, Th2, Th17 e células T reguladoras (Treg). Nesse processo, as células pró-inflamatórias Th1 produzem IFN-y, IL-2 e TNF- $\alpha$. As células antiinflamatórias Th2, entretanto, produzem IL-4, IL-5, IL-6, IL-10, e IL-13. As células 
Th17, por sua vez, podem ser a principal fonte de IL-17. As células Treg podem ser o subconjunto de células T anti-inflamatórias, responsável pela produção de IL-10 e TGF- $\beta(22,42)$.

É necessário mencionar que a importância da resposta Th1 em lesões periapicais pode ser apoiada pela análise de citocinas nos tecidos periapicais. Esses

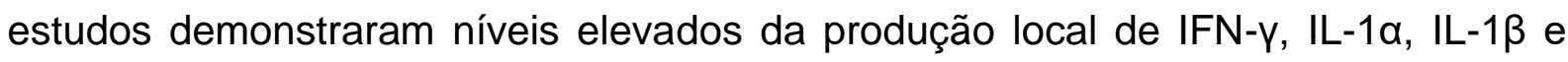
destruição óssea periapical, em camundongos tendenciosos a Th1, em comparação com os Th2 imunocompetentes. Em contraste, a IL-10, produzida por macrófagos, células Th2 e Treg pode ter um efeito inibitório forte na inflamação periapical e na destruição óssea. Por conseguinte, as vias pró-inflamatórias normalmente predominam na ausência de IL-10 $(46,47)$. Diversos estudos relataram a presença do sistema RANK/RANKL/OPG em lesões perirradiculares; no entanto, a presença específica dessas moléculas, nos diferentes compartimentos do tecido (epitélio e tecido conjuntivo) e infiltrado inflamatório (crônico ou misto) de cistos perirradiculares, ainda não foi completamente estabelecida. $O$ efeito sinérgico de citocinas pró-inflamatórias liberado por outros componentes do cisto perirradicular, tem sido sugerido como um fator que contribui para a expansão das lesões de origem endodôntica, que podem compreender células epiteliais, células endoteliais e fibroblastos, em conjunto com RANKL. Foi constatado que o tipo de infiltrado inflamatório presente nos cistos perirradiculares parece influenciar a expressão de RANK/RANKL/OPG. Na presença de infiltrado crônico, há uma grande probabilidade de aumento da atividade osteolítica como efeito de uma razão superior de RANKL / OPG (25).

No caso da periodontite, a infecção pode iniciar-se no epitélio gengival levando à gengivite, sem a perda de inserção e osso alveolar (27); sob condições específicas, poderá progredir para o tecido conjuntivo subjacente, com a perda de inserção e tecido ósseo de suporte, resultando na periodontite (26). A periodontite grave ou severa consiste em uma forma avançada da doença periodontal que representa uma inflamação crônica das estruturas de suporte dentário. Acredita-se que o biofilme bacteriano aderido ao dente seja composto de bactérias anaeróbias Gram-negativas, como Aggregatibacter actinomycetemcomitans e Porphyromonas gingivalis, os mais importantes membros desse grupo. Atualmente, reconhece-se que a destruição efetiva dos tecidos periodontais pode ser o resultado de uma superativação da resposta imune inata e adquirida, frente ao biofilme bacteriano 
(28). Assim, a doença periodontal tem sido altamente associada a outras doenças inflamatórias crônicas, tais como doença cardiovascular, síndrome metabólica, diabetes, artrite reumatoide, podendo aumentar o risco de desenvolver tais doenças (26). Nesse contexto, a doença periodontal tem sido especialmente relacionada com artrite reumatoide, visto que a perda óssea patológica também pode ser impulsionada pela resposta imune. A produção de citocinas e de RANKL por linfócitos ativados e outras células do sistema imunológico, pode impulsionar a osteoclastogênese que resulta na perda óssea associada com a doença periodontal (28). Entende-se que a periodontite crônica apresenta-se como uma oportuna forma de disseminação hematogênica de microrganismos patogênicos periodontais, devido à sua natureza crônica e cíclica, expondo suas endotoxinas diretamente nos vasos sanguíneos. Dessa forma, a periodontite pode produzir um dano tecidual e posterior progressão de outras doenças por meio de uma variedade de mecanismos celulares (48). Recentemente, um estudo em indivíduos com a doença e outros saudáveis sistemicamente demonstrou que a periodontite severa pode estar associada ao aumento dos níveis de proteína C-reativa ultrassensível circulante no soro. Por outro lado, a terapia periodontal foi associada ao decréscimo dos níveis dessa mesma proteína circulante no soro, próximos aos de indivíduos saudáveis, além do aumento de lipoproteína de alta densidade (HDL). Os níveis de proteína C-reativa ultrassensível circulante no soro e da HDL, que também se encontram alterados em outras doenças inflamatórias sistêmicas como a artrite, diabetes mellitus e obesidade, corroboram com a hipótese de que a doença periodontal pode associarse a outras doenças sistêmicas (48)

Dessa forma, a resposta inicial à infecção bacteriana pode ser uma reação inflamatória local que ativa o sistema imune inato e resulta na liberação de uma variedade de citocinas e de outros mediadores da inflamação, além da propagação e do recrutamento de células inflamatórias para o tecido gengival (26). Nesses termos, um aumento nas bactérias Gram-positivas no biofilme supragengival, tais como espécies de Streptococcus e Actinomyces, foi observado concomitante com o desenvolvimento de um infiltrado inflamatório na evolução da gengivite, dominado por células T. A presença de bactérias Gram-negativas no biofilme subgengival, como Porphyromonas gingivalis, Aggregatibacter actinomycetemcomitans, Tanerella forsythia, e Treponema denticola, foi posteriormente associada ao desenvolvimento de lesões periodontais com a presença de células do plasma (27). 
As metaloproteinases da matriz (MMPs) podem ser uma grande família de proteinases extracelulares dependentes de zinco e de cálcio (49), responsáveis pela remodelação de tecidos e degradação da matriz extracelular, incluindo colágenos, elastina, gelatina, glicoproteínas da matriz e proteoglicanos (50). Até então, pelo menos, 26 membros de MMPs foram identificados e a maioria das proteínas das MMPs, possivelmente secretada por MMPs inativas. Essas formas inativas, podem ser posteriormente processadas por outras enzimas proteolíticas (tais como as proteases de serina, furina e plasmina) para gerar as formas ativas. As atividades proteolíticas das MMPs podem ser precisamente controladas durante a ativação dos seus precursores e a neutralização por inibidores endógenos, A-macroglobulinas, inibidores teciduais de metaloproteinases (TIMPs) ou por inibidores sintéticos não seletivos. Nesses termos, evidências significativas de MMPs sugerem que elas compreendam a via mais importante na destruição do tecido associado com a doença periodontal.(50).

Com base em estudos anteriores, os níveis dramaticamente elevados de MMP-1, MMP-2, MMP-3, MMP-8 e MMP-9 foram detectados no fluido gengival crevicular, fluido sulcular peri-implante e tecido gengival de pacientes com periodontite (50). A MMP-8 (colagenase-2) e a MMP-9 (gelatinase-B) podem ser as MMPs mais comuns envolvidas na destruição dos tecidos periodontais (51). Dessa forma, entre as proteases do hospedeiro que têm como alvo a matriz extracelular, as MMPs têm sido especialmente associadas à remodelação de tecidos periodontais. As MMPs podem ser normalmente encontradas em equilíbrio com as TIMPs, para manter a remodelação da matriz altamente regulada. Em adição, MMPs e TIMPs podem ser expressos regularmente em tecidos periodontais saudáveis, onde eles podem ser recrutados para controlar a renovação fisiológica da matriz extracelular. No entanto, um desequilíbrio na razão entre MMPs/TIMPs foi descrito nos tecidos periodontais afetados e que, acredita-se, pode ser responsável pela destruição dos tecidos moles e mineralizados associado à doença periodontal. A desregulamentação do sistema de MM /TIMP (ou seja, menores níveis de TIMPs e/ou níveis mais elevados de MMPs) pode estar envolvida na patogênese de doenças osteolíticas. Dessa maneira, a inibição da MMP pode ser proposta como uma terapia adjuvante para a doença periodontal (49).

Nesses termos, a resposta das células $T$ à presença de agentes patogênicos periodontais pode ser considerada por desempenhar um papel chave na regulação 
da patogênese periodontal (27). Considerando que as células Th17 podem promover a inflamação periodontal e destruição de tecido, as células Treg podem estar implicadas na proteção contra a progressão da periodontite. Até a presente data, a ênfase foi colocada sobre a resposta das células $T$ para controlarem a imunidade local e causarem a destruição do tecido periodontal na inflamação/infecção crônica. No entanto, o papel da resposta de células $B$ na homeostase periodontal ou no desenvolvimento da doença ainda não foi completamente elucidado. As células de plasma demonstraram células $\mathrm{B}$ e um menor número de células $\mathrm{T}$, no momento em que a gengivite progrediu para periodontite (27). Nessa perspectiva, estudos atuais sugerem que a via RANK/RANKL/OPG parece ser de grande importância, além das vias metabólicas de inflamação, para ativação da reabsorção óssea em indivíduos que sofrem de doença periodontal (29). Nesse contexto, em resposta ao LPS, TNF e IFN- $\gamma$, os macrófagos $\mathrm{M} 1$ podem ser estimulados a produzirem IL-23, uma citocina que motiva a expansão de células Th 17, por produzirem IL-17, IL-1 1 , IL-6, TNF- $\alpha$, MMPs e RANKL, gerando um circuito de amplificação da inflamação (52).

Dessa forma, os avanços no conhecimento da área de osteoimunologia, tornam-se essenciais para maior compreensão desses tipos celulares em resposta à infecção e para o desenvolvimento de novos biomateriais ósseos (40). Nesse caso, patógenos e uma resposta imunoinflamatória crônica nas infecções endodônticas e periodontais persistentes são possíveis alvos para o desenvolvimento de novas terapias na endodontia e na periodontia, como a utilização de peptídeos de defesa do hospedeiro (PDHs) (21).

\subsection{1 Óxido Nítrico}

A molécula gasosa de óxido nítrico (NO) pode ser sintetizada pelo metabolismo da L-arginina e catalisada por óxido nítrico sintase (NOS) que, consiste em uma molécula de sinalização crucial para muitos sistemas biológicos humanos. A NOS pode ser apresentada em três isoformas, incluindo NOS neuronal (nNOS), NOS induzível (iNOS), e NOS endotelial (eNOS) (53). A expressão de iNOS pode ser aumentada por estímulos inflamatórios, tais como LPS bacteriano e citocinas, o que sugere que a iNOS possa desempenhar um papel crucial de proteção, durante 0 curso de infecções (54). Porém, sua produção excessiva pode causar danos 
teciduais e contribuir para a patogênese de doenças inflamatórias crônicas $(55,56)$. Nesse sentido, algumas condições inflamatórias tais como a artrite reumatóide, podem ser caracterizadas por osteólise local, associados a ativação de iNOS (57). Com base nisso, a ativação de macrófagos por meio do receptor de reconhecimento padrão, pode levar à produção de uma variedade de citocinas pró-inflamatórias. Tais citocinas incluem NO, TNF- $\alpha$, IL-1 $\beta$ (56) e IFN- - , que podem estar relacionadas com à reabsorção óssea $(57,58)$. O NO derivado de macrófagos também pode ser sintetizado pela iNOS (56). Em adição, estudos in vivo indicam que o NO pode ser necessário para a função adequada dos osteoclastos e dos osteoblastos (55). Nesse sentido, tem sido observado que o NO endógeno em baixas concentrações aumenta a atividade de osteoclastos, estimulando a reabsorção óssea. Por outro lado, em níveis excessivamente elevados, o NO pode promover a inibição da reabsorção óssea in vitro (57).

A isoforma nNOS localiza-se principalmente nas fibras nervosas pulpares, enquanto a eNOS pode ser detectada em células endoteliais e odontoblastos da polpa dentária saudável (59). Sabe-se que diversos mediadores pró-inflamatórios, tais como o NO, IL-1, IL-6 e TNF-a podem ser produzidos por macrófagos durante a pulpite (60). Além desses, os mediadores IL-10, IL-12, IFN- $\gamma$ foram altamente expressos na pulpite em experimentos com ratos. A produção, portanto, desses mediadores pró-inflamatórios aumenta excessivamente e esse constante ciclo exacerba a inflamação pulpar, cujo alívio só é possível por meio de seu bloqueio e/ou remoção da infecção (60). Nesse mesmo quadro clínico, a iNOS pode produzir elevadas quantidades de NO durante períodos prolongados, o que pode ser prejudicial, uma vez que esse mediador pode agir como um agente tóxico durante a infecção, embora suas propriedades o tornem um mediador essencial e importante na pulpite, especialmente se ele é ativado no início da inflamação (59). Em lesões perirradiculares, conforme orientações teóricas, os macrófagos e leucócitos polimorfonucleares podem ser as principais fontes de NO. Além disso, os osteoblastos e osteoclastos também podem expressar iNOS, fato indicativo do papel do NO na progressão da lesão periapical (55). Dessa maneira, estudos apontam que o NO pode ter efeito inibidor na expressão de RANKL e promover inibição da reabsorção óssea pela supressão de RANKL (55).

No ambiente periodontal, durante os processos de doença foi observado um aumento significativo na expressão de iNOS por macrófagos gengivais, células 
endoteliais e queratinócitos, o que sugere que um aumento na expressão dessa enzima, possa induzir a produção de NO nos tecidos gengivais inflamados, em resposta a periodontopatógenos. O LPS derivado de vários periodontopatógenos, tais como Aggregatibacter actinomycetemcomitans, Porphyromonas gingivalis, Prevotella intermedia, e Prevotella nigrescens tem sido demonstrado como indutor da expressão de iNOS. A produção de NO pode ser executada por uma variedade de células, incluindo a linhagem de células de macrófagos murinos RAW 264.7, células do baço murino e células osteoblásticas humanas (54).

Segundo a literatura, as células epiteliais da mucosa oral podem gerar NO em resposta às bactérias e aos estímulos pró-inflamatórios iniciados mediante a deposição de biofilme dentário. No entanto, o NO exógeno tem sido utilizado como um agente antimicrobiano. Dessa maneira, criou-se a concepção de arcabouços macromoleculares, que podem ser capazes de armazenar e liberar níveis de NO biocidas, cujo conceito sugere a aplicação de NO gasoso como uma terapia antimicrobiana, de forma lenta. Essa proposta pode ser útil contra os microrganismos patogênicos odontológicos, como os organizados dentro de biofilmes supragengival e subgengival, podendo ser favorável para o tratamento da periodontite (61). Por outro lado, tanto a perda de osso alveolar quanto abscessos em tecidos moles, induzidos por periodontopatógenos, foram inibidos em camundongos deficientes de iNOS ou tratados com inibidor de iNOS. No entanto, a cura de abscessos em tecidos moles induzidos por A. actinomycetemcomitans foi retardada em camundongos tratados com o NO exógeno (54). Diante dessas informações, pode ser possível constatar que essa relação reforça o conceito da osteoimunologia, cujo mediador da resposta imune (NO), apresenta um efeito direto na biologia óssea. Em suma, estudos em seres humanos e em animais sugerem fortemente que o NO pode desempenhar um papel significativo na progressão da doença periodontal (54) e em lesões perirradiculares (55).

\subsection{TRATAMENTO DAS PATOLOGIAS ENDODÔNTICAS E PERIODONTAIS QUE ENVOLVEM REABSORÇÃO ÓSSEA}

Em patologias odontológicas que culminam em reabsorção óssea perirradicular e periodontal, um adequado tratamento endodôntico ou tratamento 
periodontal, respectivamente, se faz necessário. O sucesso do tratamento das lesões perirradiculares pode ser dependente da eliminação do conteúdo infeccioso do sistema de canais radiculares em dentes necrosados. Para isso, deve ser realizado o preparo mecânico e o químico, quando são utilizadas soluções irrigadoras e medicação intracanal. As fórmulas das soluções irrigadoras e das medicações devem apresentar atividade antimicrobiana, além de outros agentes de desinfecção utilizados localmente que apresentam um papel chave na erradicação dos microrganismos presentes nos canais radiculares. Diversos produtos demonstram sensibilidade diferente para a ação dos distintos potenciais inativadores, como a dentina, proteínas séricas, hidroxiapatita, colágeno derivados de diferentes fontes e biomassa microbiana. O principal objetivo do tratamento endodôntico, sem dúvida, consiste em atingir a cura da lesão perirradicular (62). Nesses termos, instrumentos manuais e rotatórios têm a finalidade de modelar 0 canal radicular sob constante irrigação, para a remoção de biofilme e tecido inflamado/necrosado (62). Tanto a limpeza química, quanto a mecânica aparentam ser de suma importância durante o tratamento endodôntico (63). A instrumentação mecânica tem o objetivo de remover os tecidos infectados, propiciando o aumento das áreas de contato para a atuação das soluções irrigadoras e da medicação intracanal, favorecendo a desinfecção do sistema de canais radiculares que antecede o procedimento de obturação (64).

Nesses termos, acredita-se que periodontite seja uma doença inflamatória crônica de etiologia complexa, causada principalmente por bactérias Gram-negativas que destroem estruturas de proteção e sustentação do dente envolvendo a gengiva, o ligamento periodontal e osso alveolar. Além disso, a periodontite pode resultar na mobilidade dentária causada pela reabsorção óssea, podendo levar à perda dentária (65). Pela literatura, acredita-se que as doenças periodontais podem ser iniciadas pela colonização de microrganismos na superfície coronária e/ou abaixo da margem gengival. Embora essas infecções apresentem muitas propriedades em comum com outras doenças infecciosas, elas se diferem, devido ao seu local de colonização e à natureza do ambiente em que residem. $O$ tratamento dessas infecções é geralmente de suporte, no entanto, antibióticos costumam ser frequentemente utilizados, como adjunto, em casos mais graves (66).

Atualmente, segundo alguns autores, as terapias periodontais antimicrobianas podem ser agrupadas em três grandes categorias. Primeira, por meio da raspagem 
e alisamento corono-radicular, que consiste na remoção física dos microrganismos aderidos à coroa e raiz dentária, muitas vezes chamado debridamento mecânico. Segunda, a partir da utilização de agentes que tentam anular ou inibir o metabolismo do organismo microbiano, como antissépticos ou por meio da utilização de antibióticos (categoria pouco utilizada isoladamente, por ser considerada uma terapia adjuvante ao tratamento periodontal mecânico convencional). Terceira, a união dessas duas terapias, a fim de aperfeiçoar o benefício de cada categoria de ação. Novos tipos de terapia representam uma realidade moderadamente distante, tais como possíveis vacinas contra agentes patogênicos orais ou terapia de substituição em que uma espécie pode ser introduzida no biofilme do hospedeiro, a fim de controlar o potencial patogênico dos microrganismos (66). Dessa forma, terapias de uso padrão devem ser discutidas, a fim de gerar novas propostas terapêuticas palpáveis, na busca de um melhor controle da doença periodontal, conforme descrevem os teóricos em questão.

\subsubsection{Tratamento endodôntico}

A desinfecção adequada do sistema de canais radiculares pode ser 0 resultado de um tratamento endodôntico eficaz. Para tanto, são necessários procedimentos de preparo químico-mecânico, que podem desempenhar um papel essencial na redução da carga bacteriana no canal radicular principal, que é normalmente, a zona do sistema que abriga a maior quantidade de bactérias. $\mathrm{A}$ instrumentação mecânica, juntamente com a utilização de soluções irrigadoras (preparo químico), visam à diminuição da carga microbiana presente no canal radicular. Nesse caso, muitas vezes, se faz necessária a utilização de uma medicação com atividade antimicrobiana para aperfeiçoar a desinfecção pelo agente irrigante (67). Assim, o preparo químico-mecânico pode ser complementado pelo uso de medicação intracanal entre as sessões (68). Entende-se que, por meio da utilização dos instrumentos, medicações e técnicas endodônticas atuais tem sido praticamente impossível manter o sistema de canais radiculares estéril. Dessa maneira, o principal objetivo do tratamento endodôntico deve ser reduzir a população bacteriana intracanal para níveis que sejam compatíveis com a cicatrização do tecido perirradicular (67). É importante salientar que, o tratamento 
endodôntico pode apresentar limitações, conforme assinala a teoria; entre elas, as variações do sistema de canais radiculares e a presença de locais inacessíveis, como istmos, túbulos dentinários, canais acessórios, que muitas vezes servem de reservatórios para microrganismos em seu interior, em muitos casos inacessíveis à instrumentação endodôntica (69).

Nos casos em que o biofilme se localiza somente na entrada das ramificações dos canais acessórios, as soluções irrigadoras podem conseguir atuar na remoção do tecido por desintegração do mesmo. Por outro lado, quando as bactérias colonizam toda a extensão do canal lateral e o ligamento periodontal apresenta-se inflamado, além do tecido perirradicular local reabsorvido, esses microrganismos se tornam inacessíveis às soluções irrigadoras (70). Embora uma redução substancial nas comunidades microbianas no sistema de canais radiculares é geralmente alcançada após procedimentos químico-mecânicos, com a utilização de irrigantes antimicrobianos, tais como hipoclorito de sódio $(\mathrm{NaOCl})$, os teóricos têm demonstrado que na maioria dos casos, a desinfecção previsível pode ser alcançada com a utilização de medicação intracanal entre as sessões (68). Assim, sabe-se que os microrganismos que colonizam os canais radiculares podem entrar em contato com os tecidos adjacentes, com invasão dos túbulos dentinários, forame apical e/ou canais colaterais. Dessa maneira, $\mathrm{NaOCl}$, ácido etilenodiamino tetra-acético (EDTA), digluconato de clorexidina, peróxido de hidrogênio e compostos de iodo, podem ser exemplos de desinfetantes que podem afetar funções vitais desses patógenos (62). Mesmo com a utilização desses agentes por longos períodos de exposição, alguns microrganismos podem resistir à sua ação (63).

Nesses termos, devido aos instrumentos e irrigantes possuírem acesso limitado às ramificações, medicações intracanais devem apresentar um maior efeito desinfetante no sistema de canais radiculares (70). Dessa forma, diversas medicações intracanais podem ser utilizadas com maior frequência na endodontia, como por exemplo, o hidróxido de cálcio P.A. $\left(\mathrm{Ca}(\mathrm{OH})_{2}\right)$, o paramonoclorofenol canforado (PMCC) e o formocresol. Assim, para que uma medicação intracanal possa ser considerada ideal, deve possuir uma satisfatória atividade antimicrobiana. Em adição, se faz necessária a completa eliminação dos microrganismos que penetraram nos túbulos dentinários. Para atingir essa eliminação, as medicações devem apresentar capacidade de penetração, propriedades de dissolução e difusão pelo sistema de canais radiculares. Além disso, devem apresentar eficácia na 
inibição da diferenciação e ativação de osteoclastos, favorecendo o processo de reparo do tecido perirradicular (71). Segundo a literatura, a medicação intracanal $\mathrm{Ca}(\mathrm{OH})_{2}$, é a substância mais utilizada entre as sessões de tratamento endodôntico. $\mathrm{O} \mathrm{Ca}(\mathrm{OH})_{2}$ apresenta propriedades de alcalinidade ( $\mathrm{pH}$ de aproximadamente 12,5) e pode ser capaz de se dissociar em íons de cálcio e hidroxila em solução aquosa. Pode apresentar também atividade antimicrobiana, capacidade de dissolução do tecido, inibição da reabsorção dentária e indução de reparo pela formação de tecido duro (72). A presença do efeito alcalinizante do $\mathrm{Ca}(\mathrm{OH})_{2}$ pode induzir a quebra de ligações iônicas das estruturas terciárias de proteínas, e pode ser capaz de inibir a atividade biológica de enzimas por interferência na conformação estrutural (72).

Por outro lado, esse medicamento também pode apresentar algumas desvantagens, tais como a variação no potencial alcalino em diferentes formulações, inibição do efeito antimicrobiano pela dentina e baixa solubilidade e difusão, que requerem maior tempo de ação (73). Desse modo, estudos têm demonstrado resultados inconsistentes quanto à sua eficácia na melhoria significativa da desinfecção. Alguns autores propuseram a adição de outros medicamentos ao $\mathrm{Ca}(\mathrm{OH})_{2}$, tais como PMCC ou clorexidina, de modo a contornar as suas limitações e maximizar a eliminação de bactérias. No entanto, os estudos clínicos acerca desse tema são limitados no sentido de comparação entre as diferentes pastas de hidróxido de cálcio (68). Nesse contexto, agentes fenólicos como o PMCC, têm seu mecanismo de ação por vaporização. Assim, o acesso desse produto à porção apical pode depender da volatilidade, para entrar em contato direto com os microrganismos, apresentando um curto período de ação. Além disso, o PMCC pode ser removido pela circulação sanguínea, quando em contato com a região perirradicular (73).

Como exemplos de outras medicações intracanais, estão relacionados os biocidas que incluem álcool (etanol), aldeídos (formaldeído, glutaraldeído) e biquanidas (clorexidina), que apresentam múltiplos alvos, podendo causar danos na membrana, desnaturação de proteínas, iniciação de autólise e/ou inibição da ação de componentes citoplasmáticos (73). Por outro lado, a atividade dessas medicações pode ser afetada em baixas concentrações, mudanças de $\mathrm{pH}$ (alcalino/ácido), temperatura e presença de matéria orgânica (plasma, exsudato), entre outros (74). Durante o tratamento das lesões perirradiculares, podem ser utilizados os antibióticos, de maneira local, sistêmica ou profilática (73). Embora, sua 
utilização tópica alcance a redução significativa do número de bactérias, favorecendo a cura da lesão perirradicular, de maneira geral, o tratamento endodôntico convencional, não preconiza o uso da terapia antibiótica sistêmica concomitante. Isso se explica pela ausência de circulação sanguínea da polpa necrosada, dificultando o acesso desses agentes ao local de infecção (73). Por fim, o formocresol, outra medicação intracanal amplamente utilizada, pode ser composta de formalina e tricresol e pode possuir atividade bactericida. No entanto, o formocresol pode ser constituído por componentes irritantes e tóxicos que causam inflamação e necrose tecidual (73).

Dessa forma, o tratamento endodôntico tem por objetivo a eliminação ou a drástica redução do processo infeccioso. No momento em que a maioria dos microrganismos é eliminada, a perpetuação da lesão perirradicular em canais tratados pode ser motivada pela presença de agentes infecciosos que resistem aos procedimentos químicos e mecânicos e se adaptam ao novo ambiente (3). Nesse contexto, as lesões perirradiculares presentes em dentes tratados endodonticamente podem ser causadas por infecção intrarradicular persistente ou secundária. As infecções persistentes podem ser causadas por microrganismos que persistiram após procedimentos de desinfecção do sistema de canais radiculares e conseguiram sobreviver no canal radicular obturado; as infecções secundárias, por sua vez, são geralmente causadas por microrganismos introduzidos no canal por meio de uma falha na assepsia durante o tratamento ou por meio da infiltração coronária em canais radiculares expostos à cavidade oral. A lesão pós-tratamento endodôntico ainda pode ser classificada como emergente (que foi desenvolvida após o tratamento), persistente (que persistiu apesar do tratamento), ou recorrente (reconstruído após sua regressão). No caso da lesão recorrente, muitas vezes representa um fracasso final do tratamento endodôntico. Acredita-se que a causa esteja relacionada com o resultado de um novo evento anos após a conclusão do tratamento; por exemplo, a infiltração coronária após fratura do dente ou perda da restauração coronária permanente (75).

Em suma, os medicamentos intracanais disponíveis atualmente para utilização em tratamento endodôntico de pulpite e lesões perirradiculares, não têm todas as propriedades desejáveis, que incluem bom desempenho antimicrobiano, atividade imunomoduladora e promoção do reparo tecidual sem danos ao hospedeiro (21). Dessa forma, é necessária a pesquisa de novos produtos que 
incluam todos esses requisitos, além da capacidade de inibição da osteoclastogênese em lesões perirradiculares.

\subsubsection{Tratamento Periodontal}

Estudos demonstraram que a raspagem e alisamento radicular subgengival pode ser um efetivo meio de retardar ou paralisar a progressão da doença periodontal (30). Os tratamentos periodontais convencionais envolvem, de forma geral, os tratamentos mecânicos radiculares que têm por finalidade a remoção dos agentes causadores da doença, por meio da utilização de técnicas manuais e ultrassônicas (76). O tratamento periodontal não-cirúrgico pode constituir-se pela raspagem e alisamento coronário e radicular, manutenção periodontal, terapia fotodinâmica, entre outros (77). Entre os procedimentos cirúrgicos incluem-se gengivectomia, debridamento por meio do retalho de Widman modificado, curetagem gengival e o utilização de laser (77). Dessa forma, o padrão ouro para o tratamento da doença periodontal, consiste no debridamento mecânico do biofilme subgengival e cálculo por meio da raspagem e alisamento radicular (78). No entanto, esse tratamento apresenta limitações físicas, que incluem a dificuldade da completa eliminação de cálculo e depósitos bacterianos de bolsas periodontais profundas (79). Desse modo, o método padrão pode reduzir a carga bacteriana, mas pode não ser capaz de eliminar todos os agentes patogênicos periodontais.

Portanto, o tratamento da doença periodontal pode ser otimizado por meio da aplicação de medidas adjuvantes no controle do biofilme dentário, além de métodos de higiene mecânicos padrão. Em adição aos antibióticos sistêmicos e tópicos, uma gama crescente de diferentes soluções para bochechos antissépticos está comercialmente disponível (78). Nesse sentido, outras terapias adjuvantes incluem agentes antimicrobianos que podem ser aplicados localmente, como chips de clorexidina, gel hiclato de doxiciclina, e microesferas de minociclina. Além disso, pode ser possível a utilização de lasers como diodo, o Nd:YAG [neodímio: yttriumaluminum-garnet] e o Er:YAG [érbio: yttriumaluminum-garnet], além da terapia fotodinâmica local com uso de fonte de luz laser e agentes fotossensíveis. Em adição, podem incluir também as doses subantimicrobianas sistêmicas de doxiciclina. Os antibióticos sistêmicos e doses subantimicrobianas de doxiciclina 
sistêmicas podem ser considerados separadamente porque esse último (doses subantimicrobianas) parece inibir a atividade de colagenase em mamíferos (MMP-8) e não funcionam como um antibiótico (80).

Os antimicrobianos sistêmicos apresentam maior potencial para eventos adversos com doses mais elevadas de antimicrobianos, como a doxiciclina, por exemplo, (80), que é parte do grupo das tetraciclinas. A doxiciclina, em doses subantimicrobianas, pode ser capaz de inibir a atividade de MMPs, e assim, reduzir a degradação de macromoléculas, tais como colágeno, fibronectina e elastina no tecido periodontal. Estudo anteriores, apontam que a doxiciclina pode reduzir a diferenciação e/ou ativação de osteoclastos tanto in vitro, como em modelos in vivo (2). Outros estudos demonstraram que o gel de hiclato de doxiciclina (terapia local) pode ser um adjunto à raspagem e alisamento radicular para pacientes com periodontite moderada a crônica grave, mas o benefício na forma líquida é incerto. No entanto, na terapia local, foram relatados efeitos adversos potenciais com o uso de hiclato de doxiciclina (em altas concentrações), tais como dor de cabeça, dor de dente, dor gengival, sensibilidade dentária térmica, problemas periodontais (abscesso, exsudado, infecção, drenagem, mobilidade extrema ou supuração) ou outras inflamações na cavidade bucal (80).

A clorexidina pode ser o agente antibacteriano (como enxaguante) considerado padrão ouro na periodontia. Existem numerosos outros agentes quimioterapêuticos baseados em ingredientes ativos, utilizados como terapias de suporte à higiene bucal, por exemplo $\mathrm{NaOCl}$ e o peróxido de hidrogênio $\left(\mathrm{H}_{2} \mathrm{O}_{2}\right.$ - para tratamento de pericoronarite e abcessos), poli-hexanida, octenidina, fluoreto de amina/fluoreto estanoso, iodo e combinações de substâncias diferentes (78). Outro tratamento antibacteriano adjuvante pode ser a terapia fotodinâmica antimicrobiana, que vem se tornando cada vez mais importante, descoberta e introduzida no início do século $X X$. No entanto, os efeitos fototóxicos combinando produtos químicos especiais com luz foram descobertos pela primeira vez na utilização médica (78).

A terapia fotodinâmica recentemente começou a ser incorporada como um tratamento periodontal com características antimicrobianas específicas, porém, a eficácia e o modo de ação dessa terapia em tecidos periodontais ainda não foram completamente esclarecidas, especialmente no que diz respeito às possíveis alterações moleculares resultantes desse tratamento (76). Um estudo em humanos considerou os genes relacionados com processos imunoinflamatórios, perda óssea, 
periodontite, processo de reparação, e avaliou a expressão de níveis desses genes nos tecidos gengivais (76). Os resultados desse estudo apontam a presença de diferenças significantes na expressão de RANK e OPG antes e depois da terapia fotodinâmica. Evidências mostram que tanto RANK e OPG, quanto RANKL podem estar envolvidos no processo de reabsorção óssea. Dessa forma, foi possível observar que a terapia fotodinâmica utilizada em conjunto com raspagem e alisamento corono-radicular convencional conduz a um aumento da regulação da expressão de RANKL e OPG, que poderia indicar uma redução na atividade osteoclastogênica e consequentemente um favorecimento no reparo dos tecidos periodontais (76). Para ultrapassar as limitações da raspagem e alisamento coronoradicular e reduzir a carga bacteriana, a terapia fotodinâmica antimicrobiana tem sido proposta como uma estratégia de tratamento para a eliminação de bactérias na doença periodontal (79).

No contexto periodontal, a utilização de tetraciclinas (tais como a minociclina e a doxiciclina) pode ser um possível adjunto para o tratamento periodontal, especialmente em sistemas de distribuição local dessas drogas. No entanto, a utilização sistêmica desses antibióticos pode ter efeitos colaterais indesejáveis (61), como a descoloração de dentes em formação, distúrbios gastrointestinais, fotossensibilidade, esofagite, e raramente hipertensão intracraniana idiopática, hipersensibilidade e hepatotoxicidade (81). Nesse sentido, torna-se essencial a busca por terapias alternativas, com a finalidade de suprimir esses efeitos indesejáveis inerentes às terapias existentes atualmente.

\subsection{PEPTÍDEOS DE DEFESA DO HOSPEDEIRO}

Atualmente, é globalmente conhecida a falta de novos antibióticos para o tratamento de doenças associadas ao aparecimento de cepas bacterianas multirresistentes. Para tanto, tornou-se extremamente necessário o desenvolvimento de estratégias inovadoras para o controle desses microrganismos (82). A cavidade bucal, por exemplo, por ser exposta ao ambiente externo, abriga um grande número de microrganismos. O desequilíbrio na homeostase microbiota-hospedeiro na cavidade bucal pode provocar desde lesões cariosas, periodontite, até a perda de osso alveolar. Assim, o controle efetivo do sistema imune da cavidade bucal, pode 
ser necessário para a manutenção da saúde bucal (83). Nos mamíferos, a imunidade consiste em dois sistemas: imunidade inata e imunidade adquirida. A imunidade inata pode ser a primeira linha de defesa contra patógenos e pode ser mediada por receptores Toll-like e peptídeos antimicrobianos (PAMs) ou peptídeos de defesa do hospedeiro (PDHs) (83).

Diante disso, novas biomoléculas vêm sendo exaustivamente estudadas com o intuito de inibir o crescimento e desenvolvimento de microrganismos em biofilmes. Dessa maneira, encontra-se o suporte para a busca por peptídeos que atuem especificamente em agentes infecciosos da cavidade bucal (84). Nesse contexto, os PDHs podem ser uma classe diversificada de biomoléculas de defesa, que podem atuar inicialmente no combate à infecção e à invasão por bactérias e outros microrganismos (5). Nesse sentido, entre as características dos PDHs podem estar a baixa concentração para sua ação, atividade antimicrobiana, baixos índices de resistência devido ao mecanismo não específico e capacidade de reparo tecidual, que podem potencializar a utilização desses PDHs, como novas estratégias em terapias antimicrobianas (85). Essas moléculas podem agir por meio de diferentes mecanismos e dessa maneira, torna-se difícil de estabelecer a resistência. Assim, podem aumentar o espectro de atividade dessas biomoléculas (6), que podem agir contra uma vasta gama de microrganismos, incluindo bactérias Gram-positivas e Gram-negativas, leveduras, fungos, vírus, protozoários e parasitas (82). Os PAMs ou PDHs consistem em várias famílias distintas, podem ser conservados evolutivamente, e podem desempenhar um papel importante na imunidade inata (83).

As diferenças entre os peptídeos, além da diferença entre as superfícies bacterianas e membranas citoplasmáticas, podem representar apenas algumas das variáveis que determinam a extensão da morte bacteriana induzida pelos PDHs. Dessa maneira, torna-se possível o reconhecimento de que os peptídeos antimicrobianos podem ter outros alvos, além das membranas. Entre eles, a lactoferrina, que pode bloquear o desenvolvimento de biofilme por patógenos oportunistas. Assim, os PDHs podem ter efeitos sinérgicos com outras moléculas do sistema imune inato do indivíduo (86). Vários mecanismos de ação têm sido propostos para essas moléculas; inicialmente, os peptídeos podem interagir com a membrana celular, causando um aumento na permeabilidade concomitante com a perda da função da membrana. Além disso, os peptídeos podem afetar alvos 
intracelulares, tais como o seu núcleo e o DNA, conduzindo a apoptose (82). Nesse sentido, alguns modelos de como os danos na membrana podem ocorrer, foram descritos, visto que, a lista de moléculas antimicrobianas derivadas do hospedeiro vem sendo explorada de forma exponencial. Nesse sentido, diversos estudos vêm avaliando os mecanismos de peptídeo natural e atividade de peptídeos sintéticos, em modelo de sistemas de membranas (86).

Entre esses mecanismos, está o modelo de barril, cuja forma de organização dos peptídeos assemelha-se ao formato de um barril, podendo haver o favorecimento do extravasamento do conteúdo celular mediante interação com canais seletivos de íons (87). De outro modo, pode ser sugerido o modelo de tapete (ou carpet), onde a penetração de peptídeos na camada bilipídica forma um tapete, que pode desintegrar a membrana (88). Outro modelo descrito na literatura pode ser relacionado por meio de poros toroidal, cuja conexão contínua de monocamadas lipídicas mediante a ação de peptídeos em hélices pode ter a capacidade de interagir com a membrana celular. Essa conexão pode gerar a formação de poros e consequentemente o extravasamento de fluido (89). Semelhante ao modelo de tapete, o modelo de transição de dois estados sugere a ligação externa e desestabilização da membrana (90). Por fim, o modelo detergente, que sugere o colapso da integridade da membrana e o extravasamento de componentes intracelulares na presença de altas concentrações de peptídeos antimicrobianos (91).

Segundo a literatura, os PDHs podem ser constituídos de 12 a 50 aminoácidos, representados por conformações estruturais (folha- $\beta$, $\alpha$-hélice, estruturas em laço ou estendidas). Na maior parte dos casos, os PDHs podem ser catiônicos ou anfipáticos, o que pode determinar sua atividade antimicrobiana. Essas biomoléculas multifuncionais podem possuir, além de atividade antimicrobiana, influência na expressão de moléculas de adesão, secreção de íons de cloreto, produção de adrenocorticóide, angiogênese e reparo tecidual (92). Por serem anfipáticos, em sua maioria, os peptídeos podem ter a capacidade de interagir com a membrana citoplasmática após atravessarem os lipopolissacarídeos em bactérias Gram-negativas, e os ácidos teicóico e lipoteicóico em Gram-positivas (86).

As catelicidinas desempenham um papel crucial na manutenção da homeostase com microrganismos, assim como na promoção de respostas inflamatórias de reparação de lesões. A LL-37, por exemplo, consiste em uma 
catelicidina humana, que pode ser expressa nas glândulas salivares e na mucosa bucal em níveis moderados. Os tecidos orais de alguns pacientes com periodontite costumam exibir níveis extremamente baixos de LL-37, por isso supõe-se que podem estar envolvidos na patologia dessa doença. Esses resultados sugerem que LL-37 impede a progressão das doenças periodontais nos seres humanos (83). Dessa forma, PDHs orais podem atuar como um sistema central de defesa oral, o que determina o seu potencial terapêutico (84). Alguns produtos na área odontológica, para cuidados bucais a base de peptídeos, já estão disponíveis no mercado, como demonstrado em um estudo, descrito para combater essencialmente o biofilme microbiano (93). Além desses produtos já existentes no mercado, um fosfopeptídeo (caseína) também vem sendo comercializado como Recaldent ${ }^{T M}$ e como Tooth Mousse ${ }^{\mathrm{TM}}$, em forma de goma de mascar, apresentando atuação na remineralização do esmalte dentário (94).

Nesses termos, agentes antimicrobianos que eliminam efetivamente espécies resistentes em canais radiculares podem ser potenciais beneficiadores do tratamento endodôntico (95). Alguns estudos avaliaram a atividade de PAMs contra microrganismos relacionados à cárie e doença periodontal, incluindo Streptococcus mutans, $C$. albicans, $P$. gingivalis e $E$. faecalis. Os estudos abordavam a atividade de peptídeos orais ( $\alpha$ e $\beta$ - defensinas, LL-37, histatina e peptídeo derivado de lactoferrina), neuropeptídios, peptídeos de bactéria, peixe, boi e peptídeos sintéticos (85). Os resultados desses estudos com bactérias de alta prevalência nas doenças periodontais demonstraram que essas bactérias foram susceptíveis a LL-37, enquanto bactérias de alta prevalência em cárie foram susceptíveis à $\beta$-defensina 2 . Por outro lado, bactérias com alta prevalência nas doenças endodônticas foram susceptíveis à nisina e o fungo $C$. albicans foi susceptível à histatina 5 (85). Em adição, a $\beta$-defensina 3 humana também apresentou benefícios na terapia endodôntica e sua performance antimicrobiana foi superior ao $\mathrm{Ca}(\mathrm{OH})_{2}$ e à clorexidina (96). Esse peptídeo pode possuir propriedades antibacterianas por meio do mecanismo de tapete, antiendotoxinas, atividade imunomodulatória e baixa citotoxicidade (97).

Em resumo, os peptídeos de defesa do hospedeiro vêm sendo propostos como uma possível fonte de produtos farmacêuticos para o tratamento de infecções bacterianas resistentes a antibióticos ou choque séptico (86), o que pode incluir potenciais produtos promissores na odontologia. 


\subsubsection{Clavanina A}

As clavaninas pertencem a uma família de peptídeos antimicrobianos, expressas nos hemócitos do organismo marinho Styela clava, apresentam atividades antimicrobianas de largo espectro contra bactérias Gram-positivas e Gram-negativas, bem como contra vários fungos (98). Dessa forma, estudos demostraram que a clavanina A possui atividade contra $S$. aureus e E. coli (99). Semelhante a muitos outros peptídeos (antibióticos naturais), esses PDHs podem exercer o seu efeito antimicrobiano por meio da permeabilização das membranasalvo. Além disso, consistem em peptídeos catiônicos e anfipáticos, compostos por 23 resíduos de aminoácidos (98). As clavaninas apresentam conformação helicoidal e podem ser ricas em glicinas, histidinas, e fenilalaninas, como pode ser visto a partir de sua estrutura primária. Tais componentes podem desempenhar papéis importantes nas ações antimicrobianas da clavanina A natural (98). Além disso, apresenta carga positiva, o que pode facilitar as interações com componentes aniônicos da parede microbiana, tal como o LPS (100). A clavanina A possui atuação dependente de $\mathrm{pH}$, podendo interferir na permeabilização da membrana. Um estudo demonstrou que a bicamada lipídica foi desestabilizada em $\mathrm{pH}$ neutro com um mecanismo de ação que se assemelha ao do modelo de tapete (98). As histidinas presentes nesse PDH podem atuar mais efetivamente contra bactérias em um pH ácido (101). Em ambiente ácido, as histidinas podem ter atividade relacionada à sua interação com proteínas envolvidas na translocação de prótons (102) como proteínas de membrana (ATP sintases ou bombas de prótons, por exemplo). Esses PDHs ainda podem ser capazes de modificar a permeabilidade das membranas de bactérias Gram-negativas e Gram-positivas (101). No entanto, ainda existem controvérsias com relação ao seu mecanismo de ação (102).

Estudos anteriores in vitro com clavanina $A$, demonstraram seu perfil de avaliação em fibroblastos L929 de camundongos, bem como células primárias de pele, contra Staphylococcus aureus e Escherichia coli. Além disso, esse peptídeo foi testado em um modelo de ferida e in vivo de sepse, também com a finalidade de avaliação da resposta imune. Embora possam apresentar atividade antimicrobiana in vitro em relação às bactérias Gram-positivas e Gram-negativas, a clavanina A não demonstrou atividade citotóxica em mamíferos. Em testes de toxicidade aguda, 
nenhuma reação adversa foi observada nas concentrações testadas. Além disso, clavanina A reduziu significativamente a unidade formadora de colônias (UFC) de $S$. aureus em um modelo de ferida experimental. Em adição, esse PDH também reduziu a mortalidade de camundongos infectados com E. coli e $S$. aureus em $80 \%$, em comparação com os animais controle. Dessa forma, os resultados sugerem que clavanina A pode impedir o início da sepse e desse modo, reduzir a mortalidade. Em conclusão, esses dados sugerem que a clavanina A consiste em um PDH que poderia melhorar o desenvolvimento de novas estratégias à base de peptídeos para o tratamento de infecções de feridas e septicemia (99).

Outros estudos prévios também demonstraram que a clavanina $A$ pode apresentar atividade imunomodulatória. Além disso, sugeriu evidências na redução da osteoclastogênese in vitro (7) embora sejam necessários maiores esclarecimentos sobre a atuação das clavaninas na osteoclastogênese, que pode estar presente na doença periodontal e nas lesões perirradiculares. Assim, as clavaninas podem representar bons candidatos para um tratamento alternativo no contexto odontológico.

\subsubsection{Clavanina MO}

Com a finalidade de melhorar o seu desempenho, a clavanina $A$ foi modificada de modo a gerar uma nova molécula com melhor capacidade antibacteriana, imunomodulatória, antitumoral e com atividade antiviral. Assim, a clavanina MO foi criada com a adição de 5 resíduos de aminoácidos apolares na região C-terminal (FLPII), da sequência original clavanina $A$ (103). A sequência adicionada foi obtida mediante comparação com peptídeos descritos na literatura com atividade imunomodulatória. Esses resíduos podem aumentar o grau de hidrofobicidade e, consequentemente, a afinidade à membranas celulares (103). Um trabalho recente demonstrou que a clavanina $\mathrm{MO}$ pode ser produzida a partir da levedura Pichia pastoris, diminuindo os custos em sua produção. Além disso, apresentou efetividade contra os microrganismos Klebsiella pneumoniae (Gramnegativo) e Staphylococcus aureus (Gram-positivo) (104). Outros estudos in vitro revelaram semelhanças entre os $\mathrm{PDH}$ s clavanina $\mathrm{A}$ e clavanina $\mathrm{MO}$ quanto à ausência de citotoxicidade contra linhagem celular RAW 264.7 na concentração de 
até $190 \mu \mathrm{M}$; estímulo para a produção de IL-10; inibição na produção de NO, TNF- $\alpha$ e IL-12 (105). Em adição a isso, estudo em modelo experimental in vivo de sepse polimicrobiana grave, em camundongos, demostrou que as clavaninas $\mathrm{A}$ e $\mathrm{MO}$ obtiveram resultados semelhantes com relação a: estimulação de migração de neutrófilos à cavidade peritoneal após 6h de tratamento, ausência de efeito genotóxico, redução da carga bacteriana do ferimento e aumento de sobrevida. Esses resultados sugerem o potencial dessas biomoléculas na terapia de feridas cirúrgicas e quadros de septicemia (105).

Em síntese, baseado nos resultados obtidos com a clavanina $\mathrm{MO}$, apresentase como um PDH com potencial para a terapia endodôntica e periodontal. Tal potencial se deve às evidências demonstradas de sua provável eficácia contra infecções mistas e capacidade imunomodulatória. Além disso, ainda sugeriu evidências na redução da osteoclastogênese in vitro (7). Dessa forma, fazem-se necessárias novas buscas em relação à sua capacidade de ação em terapias endodônticas e periodontais.

\subsubsection{LL-37}

Vários peptídeos já foram descritos na literatura; desses, pelo menos 45 PDHs diferentes estão presentes no ambiente oral, derivados de saliva e de fluido gengival (5). As catelicidinas podem ser uma família de amplificadores-chaves, expressos em neutrófilos e monócitos presentes no sangue e na medula óssea, bem como em células epiteliais da superfície dos tecidos do corpo. As catelicidinas também podem ser expressas em osteoblastos e macrófagos da medula óssea (83). Entre elas, destaca-se a catelicidina LL-37, oriunda do peptídeo antimicrobiano catiônico humano 18 (hCAP18), e se apresenta como o único membro da família catelicidina em seres humanos. O hCAP18 pode ser armazenado em grânulos específicos dos neutrófilos como um pró-peptídeo inativo. Após a degranulação dos neutrófilos, o hCAP18 pode ser clivado por enzimas derivadas do hospedeiro para gerar o peptídeo LL-37 maduro (106). Esse PDH possui 37 resíduos de aminoácidos e pode ser liberado de forma ativa. Desse modo, pode formar poros na membrana bacteriana de microrganismos (84) e apresentar seus níveis de produção (de LL-37) aumentados em condições de infecção e inflamação. Em adição, a LL-37 
pode se ligar à superfície de células epiteliais e ser endocitada (107). Ela pode estar associada com a eliminação de uma ampla gama de microrganismos por interagir diretamente com as membranas celulares microbianas. Tal atividade antimicrobiana de amplo espectro, pode atingir bactérias, fungos e vírus (108). A LL-37 pode ligarse a receptores do peptídeo formil 2 (FPR2) expresso em células hospedeiras e pode provocar uma variedade de eventos, tais como quimiotaxia, proliferação celular e produção de citocinas (83).

Entre as bactérias Gram-negativas em que LL-37 pode desempenhar ação antimicrobiana, compreendem-se E. coli, $P$. aeruginosa, A. actinomycetemcomitans, Salmonella typhimurium, Salmonella minessota, B. cepacia, Capnocytophaga ochracea, Klebsiella pneumoniae, Proteus mirabilis, Stenotrophomonas maltophilia, Proteus vulgaris, Capnocytophaga sputigena, C. gingivalis, S. serovar dublin. Já, entre as Gram-positivas, LL-37 pode apresentar ação sobre as espécies de Streptococcus, S. aureus, E. faecalis, Staphylococcus epidermidis, Listeeria monocytogenes, Enterococcus faecium, Lactobacillus. acidophilus, Bacillus subtilis, Bacillus megaterium. Além desses, pode atuar ainda no fungo C. albicans (108).

Algumas doenças humanas podem estar associadas a uma expressão alterada de LL-37; por exemplo, na síndrome Kostman Morbus que pode ser causada pela ausência de neutrófilos, que resulta na deficiência de LL-37, que pode ainda conduzir a infecções periodontais repetidas e severa reabsorção do osso alveolar (109). Além disso, a LL-37 pode ser capaz de neutralizar LPS e flagelina, e ainda pode suprimir diretamente osteoclastogênese em seres humanos, pois evidências sugerem que catelicidinas produzidas por osteoblastos em resposta ao LPS, flagelina e lipoproteínas acilados, podem atuar como protetores contra a reabsorção óssea induzida por infecção bacteriana em doenças periodontais. No entanto, a $P$. gingivalis pode degradar a LL-37, utilizando suas próprias proteases. Por conseguinte, o desenvolvimento de variantes de LL-37, que sejam resistentes à clivagem proteolítica é almejado para o tratamento da periodontite (83).

Outra característica importante, pode ser sua capacidade imunomodulatória (107); as ações biológicas de LL-37 podem incluir angiogênese e promoção da cura de feridas, induzindo à proliferação de células. De modo semelhante, a LL-37 não foi detectada no fluido crevicular gengival de pacientes com grave perda de osso alveolar devido à periodontite. Surgiu então a hipótese de que a LL-37 pode afetar negativamente a formação e função dos osteoclastos (109). Nesses termos, 
acredita-se que a ativação das células dendríticas, derivadas da mesma linhagem dos osteoclastos, pode ser inibida pela LL-37. Estudos sugerem que a LL-37 pode suprimir a osteoclastogênese, no entanto, não se sabe se afetam a formação e/ou função dos osteoclastos (109). A deficiência de LL-37 vem sendo relacionada à periodontite agressiva, hipótese que sugere que a LL-37 pode inibir a osteoclastogênese, já que a sua deficiência faria com que a reabsorção óssea severa fosse observada na periodontite agressiva (109).

De outro modo, a LL-37 também pode exercer funções biológicas essenciais para o ambiente perirradicular, como angiogênese e indução de proliferação celular (110), sugerindo sua ação no ambiente endodôntico. Estudos anteriores evidenciaram que a LL-37 foi capaz de induzir a migração de células de polpa dentária humana, assim como o fator de crescimento epidérmico (EGF), de aumentar os níveis dos receptores de EGF fosforilados, podendo, também atuar na migração de queratinócitos e fibroblastos. Dessa forma, tal atuação da LL-37 pôde ser inibida pelo antagonista do receptor de EGF, de modo a sugerir que a indução da migração de células de polpa humana via LL-37 se dê pela transativação de receptores de EGF mediados por $\operatorname{EGF}(111,112)$. Diante dessas informações, evidências apontam que a LL-37 pode ser um importante agente na redução da osteoclastogênese, devido à presença de osteoclastos na doença periodontal e nas lesões perirradiculares, há uma forte motivação na busca de medicações que contenham essas ações. Isto se faz importante no ambiente oral acometido por tais doenças e/ou suas consequências.

Como justificativa, o processo de remodelação óssea consiste em um importante mecanismo para o metabolismo e homeostase do sistema esquelético humano. No entanto, o desequilíbrio desse processo pode acarretar o desenvolvimento de graves doenças, visto que, na odontologia, o insucesso no tratamento de lesões perirradiculares e da periodontite resulta em reabsorções ósseas exacerbadas nessas áreas. As falhas no tratamento podem abranger desde recolonização de microrganismos mesmo sob o uso de medicações utilizadas aualmente, até a incapacidade de resposta imune do hospedeiro. Nesse caso, fazse necessária a busca por novas terapias que reduzam ou eliminem essas falhas. Assim, os peptídeos de defesa do hospedeiro podem ser biomoléculas promissoras 
para o desenvolvimento de medicações intracanais e distribuição local nos tecidos periodontais, devido sua atividade imunomodulatória e antimicrobiana por meio de diferentes mecanismos, dificultando a resistência. Portanto, este trabalho visa à avaliação da viabilidade celular e expressão de NO, que podem ser importantes na osteoclastogênese de células RAW 264.7, mediadas pelo rRANKL, na presença dos peptídeos de defesa do hospedeiro clavanina A, clavanina MO e LL-37, comparados aos controles clínicos $\mathrm{Ca}(\mathrm{OH})_{2}$ e doxiciclina. 


\section{OBJETIVOS}

\subsection{OBJETIVO GERAL}

Avaliar os peptídeos clavanina A, clavanina MO e catelecidina LL-37 no processo de osteoclastogênese mediada por rRANKL em comparação com os controles clínicos hidróxido de cálcio P.A. $\left(\mathrm{Ca}(\mathrm{OH})_{2}\right)$ e doxiciclina.

\subsection{OBJETIVOS ESPECÍFICOS}

$\checkmark \quad$ Avaliar a viabilidade e proliferação celular de culturas de precursores de osteoclastos RAW 264.7, na presença dos peptídeos clavanina A, clavanina MO e LL-37 e das medicações $\mathrm{Ca}(\mathrm{OH})_{2}$ e doxiciclina em diferentes concentrações, com ou sem estímulo do recombinante ( $r$ ) RANKL, por meio do método de ensaio colorimétrico de viabilidade celular de 3-(4,5-dimetiltiazol-2yl)-2,5-difenil brometo de tetrazolina (MTT).

$\checkmark \quad$ Avaliar a produção de NO nas culturas de precursores de osteoclastos RAW 264.7, na presença dos peptídeos clavanina A, clavanina MO e LL-37, e das medicações $\mathrm{Ca}(\mathrm{OH})_{2}$ e doxiciclina em diferentes concentrações, com ou sem estímulo de rRANKL.

$\checkmark \quad$ Avaliar o número de osteoclastos diferenciados após coloração de TRAP, na presença dos peptídeos clavanina A, clavanina MO e LL-37 e das medicações $\mathrm{Ca}(\mathrm{OH})_{2}$ e doxiciclina em diferentes concentrações, com ou sem estímulo de rRANKL.

$\checkmark \quad$ Correlacionar a concentração mínima dos peptídeos clavanina A, clavanina MO e LL-37 e das medicações $\mathrm{Ca}(\mathrm{OH})_{2}$ e doxiciclina, capaz de reduzir ou inibir a diferenciação de osteoclastos, com sua respectiva produção de NO. 


\section{MÉTODOS}

\subsection{CARACTERIZAÇÃO DO ESTUDO}

O presente estudo visou à avaliação do papel funcional da osteoclastogênese mediada por recombinante (r) RANKL in vitro, a partir de culturas da linhagem de pré-osteoclastos RAW 264.7, na presença dos peptídeos clavanina A, clavanina MO e LL-37, em comparação com o $\mathrm{Ca}(\mathrm{OH})_{2}$ (a medicação intracanal convencional na endodontia) (72) e a doxiciclina (medicação utilizada no tratamento periodontal) (30), conforme ilustrado na figura 1. Para tanto, o estudo foi dividido em grupos de culturas da linhagem de pré-osteoclastos RAW 264.7 com e sem rRANKL. Cada uma dessas culturas foi exposta às diferentes concentrações dos peptídeos $(2,8$, 32, e $\left.128 \mu \mathrm{g} \cdot \mathrm{mL}^{-1}\right)$, além da doxiciclina e do $\mathrm{Ca}(\mathrm{OH})_{2}$ nas mesmas concentrações utilizadas $\left(2,8,32\right.$, e $\left.128 \mu \mathrm{g} \cdot \mathrm{mL}^{-1}\right)$. Foram realizadas análises baseadas nos testes de viabilidade celular (MTT), dosagem de óxido nítrico (NO) e contagem de osteoclastos diferenciados, após coloração de tartarato fosfatase ácido resistente (TRAP). Foram realizadas três réplicas biológicas em triplicatas técnicas. O objetivo foi avaliar a menor concentração dos peptídeos, da doxiciclina e do $\mathrm{Ca}(\mathrm{OH})_{2}$, capaz de reduzir ou inibir a osteoclastogênese mediada por rRANKL in vitro. 


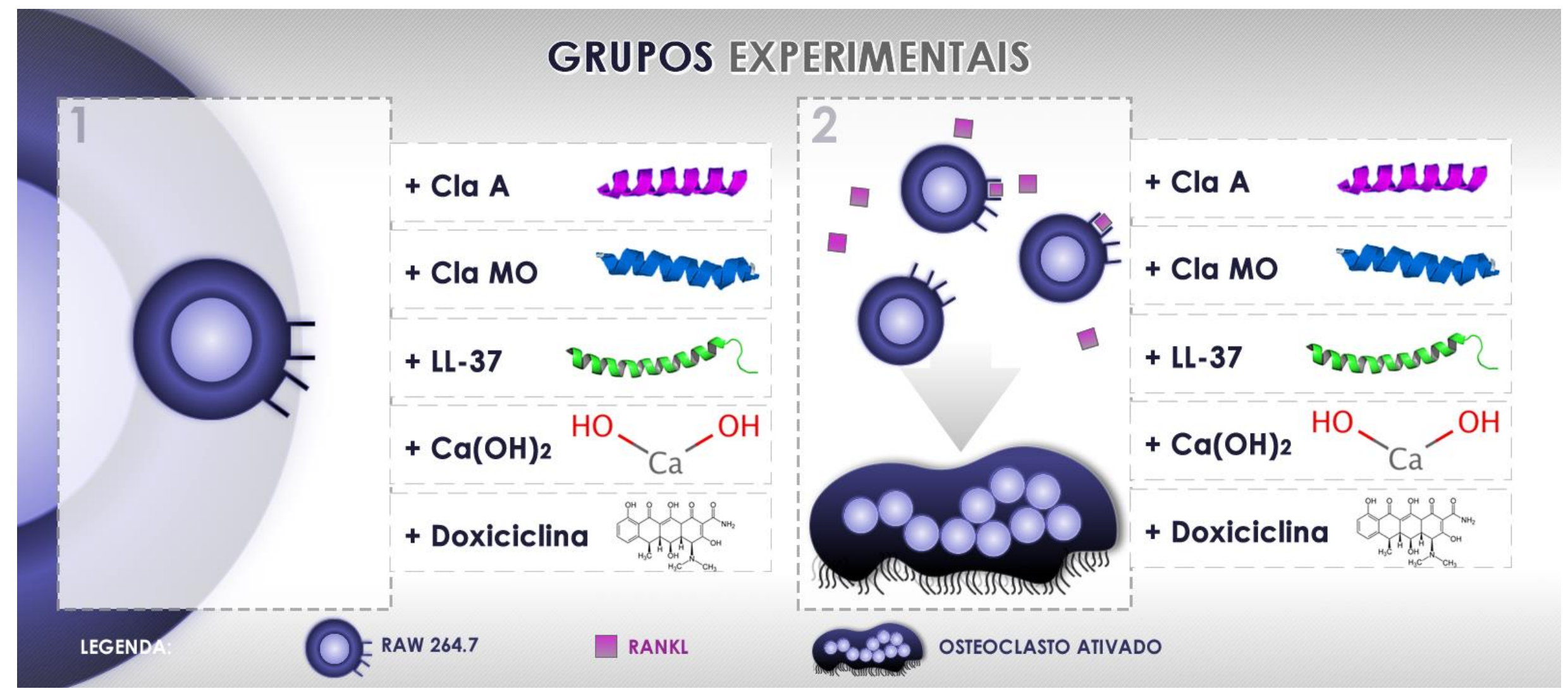

Figura 1- Linhagem de pré-osteoclastos RAW 264.7, divididos em 2 grupos: Grupo controle 1, linhagem de pré-osteoclastos RAW 264.7; Subgrupos - células RAW 264.7 com a adição de clavanina A, clavanina MO, LL-37, $\mathrm{Ca}(\mathrm{OH})_{2}$ e doxiciclina. Grupo controle 2, células RAW 264.7 estimuladas com o rRANKL; Subgrupos - células RAW 264.7 estimuladas com o rRANKL, com a adição de clavanina A, clavanina MO, LL-37, $\mathrm{Ca}(\mathrm{OH})_{2}$ e doxiciclina. 


\subsection{OBTENÇÃO DA LINHAGEM CELULAR}

As células pré-osteoclásticas da linhagem RAW 264.7 foram obtidas do Banco de Células do Rio de Janeiro, Rio de Janeiro, Brasil (CR108). Essas células foram cultivadas em meio de cultura DMEM (Gibco, Califórnia, EUA) suplementado com $10 \%$ de soro fetal bovino (Gibco ${ }^{\circledR}$ ), 1\% penicilina/estreptomicina (1000 U.mL ${ }^{-1}$ ) (Gibco ${ }^{\circledR}$ ), 1\% de solução de aminoácidos não essenciais MEM (Gibco ${ }^{\circledR}$ ), 1\% de Lglutamina $\left(\right.$ Gibco $\left.^{\circledR}\right)$ e $0,1 \%$ de gentamicina (Gibco ${ }^{\circledR}$ ) e mantidas em estufa, contendo $5 \%$ de $\mathrm{CO}_{2}$, a $37^{\circ} \mathrm{C}$ e umidade a $95 \%$. Durante a manutenção das células, a cada três dias, ocorreu a troca de meio de cultura ou repique em caso de confluência igual ou superior a $75 \%$. Os experimentos para dosagem de NO, ensaio de MTT e contagem de osteoclastos, após coloração TRAP, foram realizados em culturas com

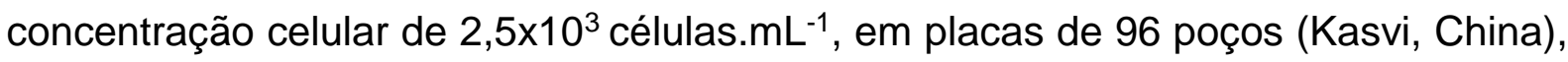
estimuladas com e sem $100 \mathrm{ng} \cdot \mathrm{mL}^{-1}$ de rRANKL (Peprotech, Nova Jersey, EUA) nos grupos controles e acrescidas de diferentes concentrações $\left(2,8,32\right.$, e $\left.128 \mu \mathrm{g} \cdot \mathrm{mL}^{-1}\right)$ dos peptídeos clavanina A, clavanina MO e LL-37, e dos controles clínicos doxiciclina e $\mathrm{Ca}(\mathrm{OH})_{2}$, de acordo com a definição dos grupos experimentais (figura 1). Durante todo o período experimental, as culturas permaneceram em estufa contendo $5 \%$ de $\mathrm{CO}_{2}$, a $37^{\circ} \mathrm{C}$ e umidade a $95 \%$. Nos experimentos envolvendo cronologia de sete dias ( $7 \mathrm{~d}$ ), a cada três dias, metade do volume de meio de cultura e dos estímulos utilizados em cada grupo experimental foram trocados. Ao final de cada tempo experimental, foram realizados os ensaios de MTT e dosagem de NO. Ao final do sétimo dia, além dessas análises, foi realizada também a coloração de TRAP, seguida da contagem do número de osteoclastos diferenciados.

\subsection{SÍNTESE E PURIFICAÇÃO DOS PEPTÍDEOS CLAVANINA A, CLAVANINA MO E LL-37}

Os peptídeos clavanina A, clavanina MO e LL-37 foram sintetizados de acordo com a metodologia de síntese em fase sólida mediante estratégia F-moc (113), purificados (>95\%), liofilizados e armazenados pela empresa Peptides 2.0 Inc., EUA (tabela 1). Após a aquisição dos peptídeos, eles foram checados por meio 
de espectrometria de massas Matrix Assisted Laser Desorption Ionization - Time of Flight (MALDI-ToF), para certificação da sua pureza e massa molecular. Para essa confirmação, os peptídeos foram diluídos em água ultrapura e analisados em matriz (ácido saturado a-ciano-4-hidroxicinâmico, preparada com $50 \mu \mathrm{L}$ ácido trifluoroacético a $3 \%$, acetonitrila $100 \%$ e $200 \mu \mathrm{L}$ de água ultrapura), no volume de 1:3. Logo, foram aplicadas em placa Anchorchip Var-384 em triplicatas e, em temperatura ambiente, aguardou-se até a completa secagem da amostra. A massa molecular foi determinada via MALDI-ToF Ultra Flex III (Bruker Daltonics, Billerica, MA). A massa monoisotópica foi obtida com o uso de Peptide Calibration Standard II para espectrometria de massa (Bruker Daltonics, Billerica, MA), a partir do modo de operação refletivo e positivo com calibração externa. Um dos peptídeos testados a LL-37, em seu espectro de massa, demonstrou impurezas, isto é, a presença de íons não compatíveis com o peptídeo ou íons compatíveis com degradação de amostra; por esse motivo, o peptídeo foi submetido à purificação por cromatografia líquida de alta eficiência em fase reversa (RT-HPLC). Para sua purificação, a LL-37 foi solubilizada em água ultrapura $(500 \mu \mathrm{g})$ e submetida à coluna semi-preparativa C18 (NST, $5 \mu \mathrm{m}, 250 \mathrm{~mm} \times 10 \mathrm{~mm}$ ), sendo eluída com um gradiente linear de acetonitrila (5-95\%) por 60 minutos (min), a um fluxo de 2,5 mL. $\mathrm{min}^{-1}$. As frações, monitoradas a $216 \mathrm{~nm}$, foram coletadas e, em seguida, foram liofilizadas. Posteriormente à purificação, a amostra de LL-37 foi analisada novamente por MALDI-ToF, para certificação de sua pureza (Anexo 1). Para os experimentos, os peptídeos foram diluídos em água ultrapura e quantificados pela absorção UV a 205, 215 e $225 \mathrm{~nm}$, com a seguinte fórmula de concentração (114):

$$
\begin{gathered}
\mathrm{A}=(\mathrm{A} 215-\mathrm{A} 225) \times 144 \\
\mathrm{~B}=(\mathrm{A} 205) \times 31 \\
\frac{A+B}{2}=\mathrm{mg} \cdot \mathrm{mL}^{-1}
\end{gathered}
$$

Por fim, após identificação e fracionamento ideal para cada um dos experimentos, os peptídeos foram mantidos a $-20^{\circ} \mathrm{C}$ até sua utilização. Quando descongelados, foram usados uma única vez e não armazenados novamente, evitando assim que esses peptídeos fossem degradados nesse processo. 
Tabela 1 - Sequência e massa molecular dos peptídeos clavanina A, clavanina MO e LL-37

\begin{tabular}{ccc}
\hline Peptídeo & Sequência & $\begin{array}{c}\text { Massa } \\
\text { molecular (Da) }\end{array}$ \\
\hline $\begin{array}{c}\text { clavanina } \\
\text { A }\end{array}$ & VFQFLGKIIHHVGNFVHGFSHVF-NH 2 & 2667.08 \\
clavanina & & \\
MO & FLPIIVFQFLGKIIHHVGNFVHGFSHVF-NH 2 & 3249.75 \\
LL-37 & LLGDFFRKSKEKIGKEFKRIVQRIKDFLRNLVPRTES-NH 2 & 4491.03 \\
\hline
\end{tabular}

\subsection{OBTENÇÃO DO HIDRÓXIDO DE CÁLCIO E DA DOXICICLINA}

$\mathrm{O} \mathrm{Ca}(\mathrm{OH})_{2}$ (Biodinâmica, Paraná, Brasil) foi analisado quanto à sua pureza e solubilidade em água pela empresa Soloquímica - Análises de Solo Ltda. $\mathrm{O} \mathrm{Ca}(\mathrm{OH})_{2}$ foi pesado e diluído em água ultrapura (20 $\left.\mathrm{mg}^{\mathrm{mL}} \mathrm{mL}^{-1}\right)$, no momento anterior a cada um dos experimentos. A doxiciclina (Pharmac, Brasília, Brasil) foi manipulada em cápsulas, na concentração de $100 \mathrm{mg}$ em cada unidade. As cápsulas foram abertas e a doxiciclina foi pesada e diluída em água ultrapura (20 mg.mL-1 $)$, no momento da utilização no experimento.

\subsection{ENSAIO DE VIABILIDADE CELULAR}

O ensaio de viabilidade celular foi utilizado para determinar a citotoxicidade dos peptídeos, do $\mathrm{Ca}(\mathrm{OH})_{2}$ e da doxiciclina. O método utilizado foi o MTT (SigmaAldrich, St Louis, EUA), que avalia a atividade da enzima desidrogenase mitocondrial. Além disso, o MTT consiste em um método colorimétrico, baseado na capacidade de as células vivas reduzirem o sal 3-(4,5-di-metilazol-2-il)-2,5-difenil tetrazolium brometo no produto formazan (115). Foram analisados os tempos experimentais de 72 horas ( $72 \mathrm{~h}$ ) e 7 dias ( $7 \mathrm{~d}$ ), em todos os grupos experimentais, além do controle negativo, representado pela cultura celular em solução de lise (meio de cultura DMEM, células na concentração $2,5 \times 10^{3}$ células. $\mathrm{mL}^{-1}$ e solução de lise - 10 mM Tris, pH 7,4, 1 mM EDTA e 0,1\% triton X-100) (116). Após 72 h e 7 d de 
incubação, parte do sobrenadante foi removida, permanecendo apenas $45 \mu \mathrm{L}$ deste em cada poço. Foram acrescidos $10 \mu \mathrm{L}$ de MTT $\left(0,05 \mathrm{mg}_{\mathrm{mL}}{ }^{-1}\right)$ (Sigma-Aldrich), por poço, da placa de 96 poços (Kasvi), e as placas acondicionadas em estufa com $5 \%$ de $\mathrm{CO}_{2}, 37^{\circ} \mathrm{C}$ e $95 \%$ de umidade, durante 4 horas. Finalizado esse período, a reação foi bloqueada com $60 \mu \mathrm{L}$ por poço de dimetilsulfóxido (DMSO) (JT Barker, Europa) e os poços foram homogeneizados para completa solubilização do conteúdo celular. Em seguida, foi realizada a leitura em leitor de microplacas (BioTek Power Wave HT, EUA), com absorbância a $595 \mathrm{~nm}$. Os resultados dos grupos experimentais foram subtraídos da amostra "branco" (meio de cultura, exclusivamente) e o percentual de viabilidade celular foi estabelecido após comparação com o grupo controle positivo (RAW 264.7), considerado como 100\% de viabilidade celular.

\subsection{DOSAGEM DE ÓXIDO NÍTRICO}

Outro parâmetro analisado neste estudo foi a dosagem de óxido nítrico. A produção de nitrito nos sobrenadantes das culturas foi avaliada pelo método de Green et al. (1982), com adaptações (117). A avaliação dos níveis de nitrito foi estabelecida nos sobrenadantes das culturas celulares, estimuladas com diversas concentrações dos peptídeos, da doxiciclina e do $\mathrm{Ca}(\mathrm{OH})_{2}$. Para tanto, $100 \mu \mathrm{L}$ do sobrenadante de ambos os tempos experimentais (72 $\mathrm{h} \mathrm{e} 7 \mathrm{~d}$ ) foram transferidos para uma nova placa de 96 poços (Kasvi). Para a curva padrão de nitrito de sódio, foram realizadas diluições sucessivas em meio DMEM (Gibco $\left.{ }^{\circledR}\right)(1,5625 \mu \mathrm{M}$ a 200 $\mu \mathrm{M})$. Em seguida, foram adicionados $100 \mu \mathrm{L}$ de uma solução de sulfanilamida a $1 \%$, em ácido fosfórico 2,5\%, e naftiletilenodiamina $1 \%$, em ácido fosfórico 2,5\%, na proporção de 1:1. Após 10 min de incubação à temperatura ambiente, foi realizada a leitura em leitor de microplacas (Bio-Tek Power Wave HT, EUA), a $490 \mathrm{~nm}$. A quantidade de nitrito foi calculada a partir da equação da curva padrão (117). 


\subsection{OSTEOCLASTOGÊNESE E COLORAÇÃO DE FOSFATASE ÁCIDA TARTARATO RESISTENTE (TRAP)}

Ao final de $7 \mathrm{~d}$ de experimento, as culturas celulares realizadas em placas de 96 poços (Kasvi), de acordo com os grupos controle ou experimentais, foram submetidas à coloração de TRAP para posterior contagem do número de osteoclastos diferenciados. Para realização da coloração de TRAP, foi utilizado o kit Acid Phosphatase Leukocyte (Sigma-Aldrich, St. Louis, EUA), com adaptações. Para tanto, foi removido todo o sobrenadante da cultura celular e adicionado, a cada poço, $100 \mu \mathrm{L}$ de solução fixadora $(0,7 \mathrm{~mL}$ de solução de citrato, $1,9 \mathrm{~mL}$ de acetona e $0,2 \mathrm{~mL}$ de formaldeído $37 \%$ ), permitindo que a fixação ocorra durante $2 \mathrm{~min}$, lavados com $100 \mu \mathrm{L}$ de água destilada. Em seguida, foi preparada a solução de coloração por meio da união de $2,7 \mathrm{~mL}$ de água destilada a $37^{\circ} \mathrm{C}, 0,20 \mathrm{~mL}$ de solução corante fast garnet, sal sulfato GBC diazotada $(0,10 \mathrm{~mL}$ de solução $\mathrm{GBC}$ e $0,10 \mathrm{~mL}$ de solução de nitrito de sódio), 0,03 mL de solução de naphtol AS-TR fosfato, 0,12 mL de solução de acetato e $0,06 \mathrm{~mL}$ de solução de tartrato. Esses foram aquecidos em banho-Maria a $37^{\circ} \mathrm{C}$ e, logo, $100 \mu \mathrm{L}$ dessa solução foram adicionados a cada poço. A placa foi envolvida em papel alumínio, devido a componentes dessa solução serem fotossensíveis; em seguida, foi incubada em estufa a $37^{\circ} \mathrm{C}$, durante 1 hora. Ao final desse período, a solução foi removida e o poço lavado com $100 \mu \mathrm{L}$ de água destilada. Para coloração do núcleo, após remoção da água destilada, foram adicionados $60 \mu \mathrm{L}$ da solução de hematoxilina, por 30 segundos (seg). Após esse tempo, três lavagens com água destilada foram realizadas, com duração de $1 \mathrm{~min}$ cada, e os osteoclastos (células TRAP positivas, com mais de três núcleos em seu interior (118)) foram contabilizados em microscópio invertido. Essa contagem foi realizada de maneira manual (com o auxílio de um contador manual), onde um ponto de referência inicial foi marcado no poço a ser contado da placa de 96 poços (Kasvi). Dessa maneira, foram contados os osteoclastos fixados na placa a partir desse ponto inicial e avaliando cada espaço do poço, conduzindo a placa em movimentos circulares, das bordas ao centro do poço (em forma de espiral), até que todo poço fosse contabilizado. 


\subsection{ANÁLISE ESTATÍSTICA}

Quanto à análise estatística, os resultados foram submetidos ao cálculo da média e erro padrão para cada experimento. Em seguida, foi realizada a verificação de normalidade (teste de Kolmogorov Smirnov) e posterior análise estatística paramétrica, mediante a análise de variância de um fator (one way ANOVA) e pósteste de Tukey. Os experimentos (avaliação citotóxica, dosagem de óxido nítrico e osteoclastogênese) seguiram um padrão de comparação entre o controle e todos os grupos em cada tempo experimental. As análises, realizadas no software Graph Pad Prism 6.0, foram consideradas a um nível de significância de $95 \%$, com valor de $\mathrm{p}<0,05$. 


\section{RESULTADOS}

\subsection{VIABILIDADE CELULAR EM DIFERENTES CONCENTRAÇÕES DE PEPTÍDEOS E CONTROLES CLÍNICOS}

Para a análise da viabilidade celular, o ensaio colorimétrico de MTT (Sigma, EUA) foi efetuado após 72 h e 7 d de cultura de células pré-osteoclásticas RAW 264.7 na presença de peptídeos clavanina A, clavanina MO, LL-37 e controles clínicos de $\mathrm{Ca}(\mathrm{OH})_{2}$ e doxiciclina. O método colorimétrico de MTT é baseado na capacidade das células vivas de reduzirem o sal 3-(4,5-di-metilazol-2-il)-2,5-difenil tetrazolium brometo no produto formazan e consiste na avaliação da atividade da desidrogenase mitocondrial (115). O presente ensaio foi conduzido a fim de verificar a citotoxicidade dos produtos testados, na presença e ausência do rRANKL. Foi observado que as concentrações 2, 8, 32, e $128 \mu \mathrm{g} \cdot \mathrm{mL}^{-1}$ dos peptídeos e do $\mathrm{Ca}(\mathrm{OH})_{2}$ (Figuras $2 \mathrm{~A}, \mathrm{~B}, \mathrm{C}$ e D) não apresentaram nenhum grau de citotoxicidade para as células RAW 264.7. Em adição, em algumas concentrações, esses produtos possivelmente estimularam a proliferação celular $(p<0,05)$. No entanto, as células

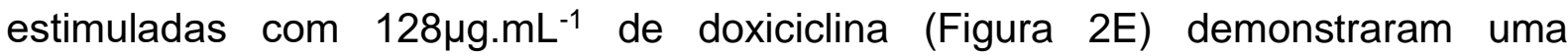
diminuição na viabilidade celular $(p<0,05)$, permanecendo apenas $52 \%$ de células vivas, após 72 h de cultivo celular, em comparação com o controle representado apenas por culturas contendo células RAW 264.7. No entanto, baixas concentrações (2 e $8 \mu \mathrm{g} \cdot \mathrm{mL}^{-1}$ ) de doxiciclina, possivelmente estimulam a proliferação celular, ao final de $7 d$ de incubação $(p<0,05)$.

De maneira semelhante, foram observadas as mesmas condições de viabilidade quando a cultura de células RAW 264.7 foi estimulada com $100 \mathrm{ng} \cdot \mathrm{mL}^{-1}$ de rRANKL e acrescida dos peptídeos clavanina A, clavanina MO, LL-37 e dos controles clínicos de $\mathrm{Ca}(\mathrm{OH})_{2}$ e doxiciclina, após 72 h e $7 \mathrm{~d}$ (Figura 3). Os peptídeos e controles clínicos, nas concentrações de 2, 8, 32, e $128 \mu \mathrm{g} \cdot \mathrm{mL}^{-1}$ não foram citotóxicos para as culturas estimuladas com rRANKL e novamente, em algumas concentrações parecem estimular a proliferação celular em culturas acrescidas de peptídeos e $\mathrm{Ca}(\mathrm{OH})_{2}(\mathrm{p}<0,05)$ (Figuras $3 \mathrm{~A}, \mathrm{~B}, \mathrm{C}$ e D). Uma exceção foi observada, nas culturas estimuladas com rRANKL e doxiciclina na concentração $128 \mu \mathrm{g} \cdot \mathrm{mL}^{-1}$, 
após 72 h (Figura 3E). Este grupo demonstrou um decréscimo na viabilidade celular em comparação com culturas de células RAW 264.7 estimuladas com rRANKL, reduzindo-se para apenas $58 \%$ de células vivas $(p<0,05)$. No entanto, $2 \mu \mathrm{g} \cdot \mathrm{mL}^{-1}$ de doxiciclina também manteve o padrão observado nas culturas com ausência do estímulo de rRANKL, onde observou-se uma provável proliferação celular, ao final de ambos os tempos experimentais $(p<0,05)$. 
(A)

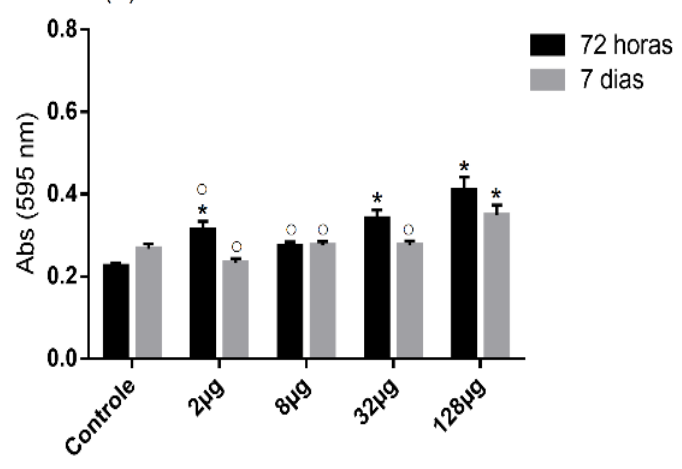

(C)

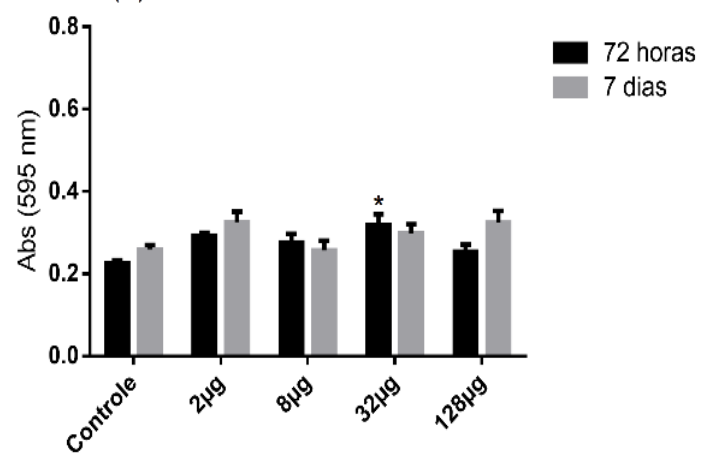

(B)

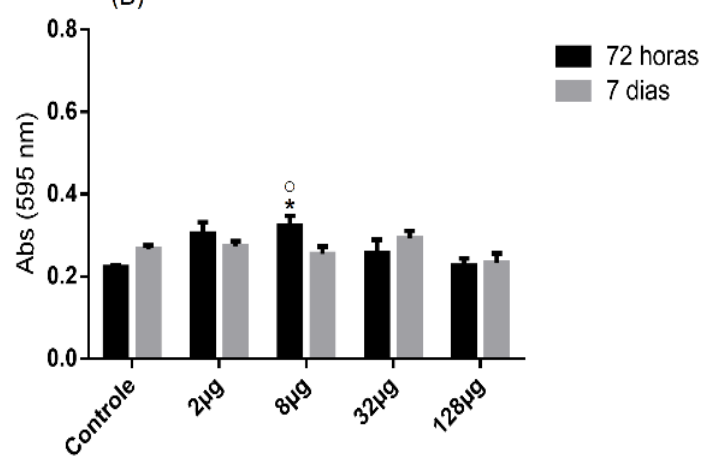

(D)

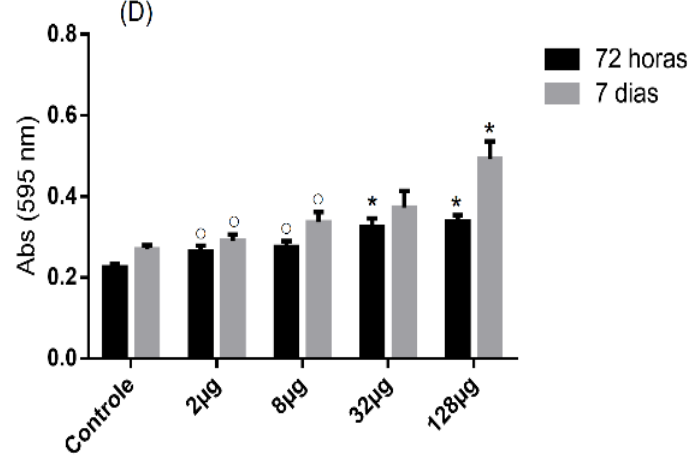

(E)

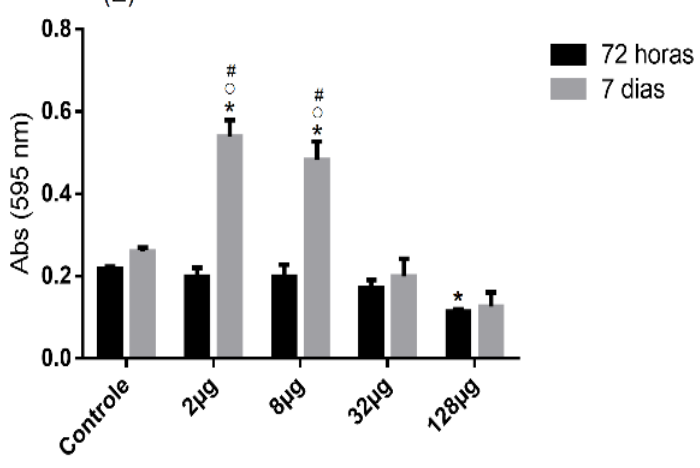

Figura 2: Citotoxicidade dos peptídeos clavanina A (A), clavanina MO (B), LL-37 (C) e controles

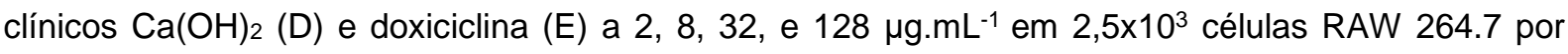

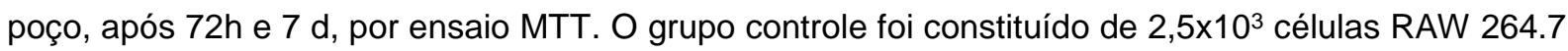
por poço. A viabilidade celular foi representada por média e o erro padrão, na absorbância de 595 $\mathrm{nm}$, realizado em triplicata técnica e biológica. ${ }^{*} \mathrm{p}<0,05$ comparando-se ao grupo controle, em cada condição testada. op<0,05 comparando-se aos grupos contendo $128 \mu \mathrm{g} \cdot \mathrm{mL}^{-1}$ de cada produto, em cada condição testada. \#p<0,05 comparando-se aos grupos contendo $32 \mu \mathrm{g} \cdot \mathrm{mL}^{-1} \mathrm{de}$ cada produto, em cada condição testada. 
(A)

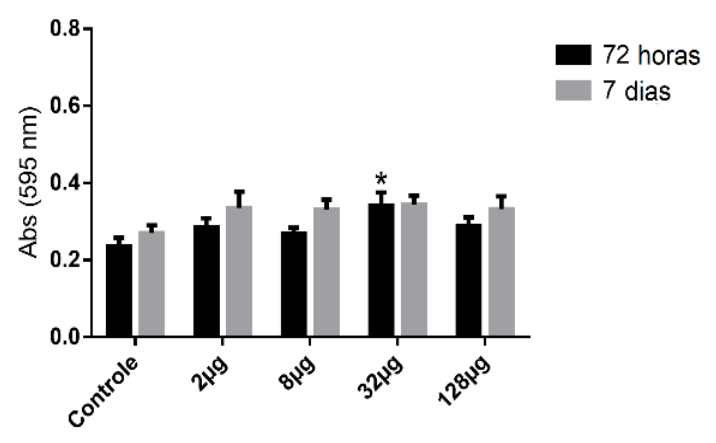

(C)

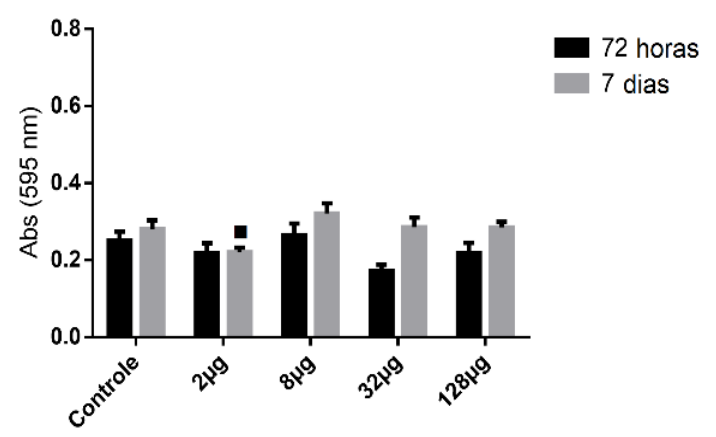

(B)

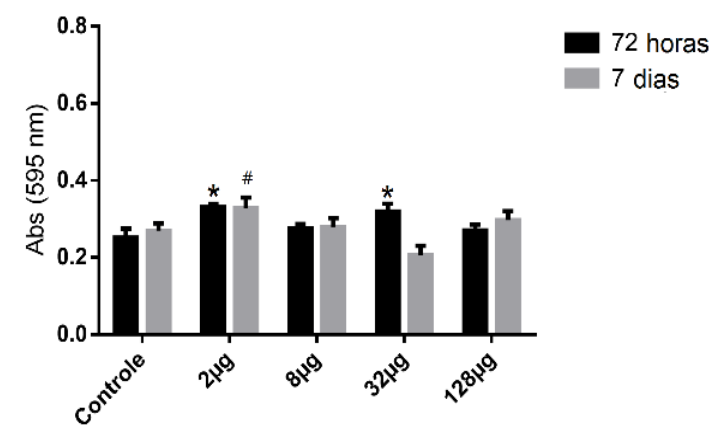

(D)

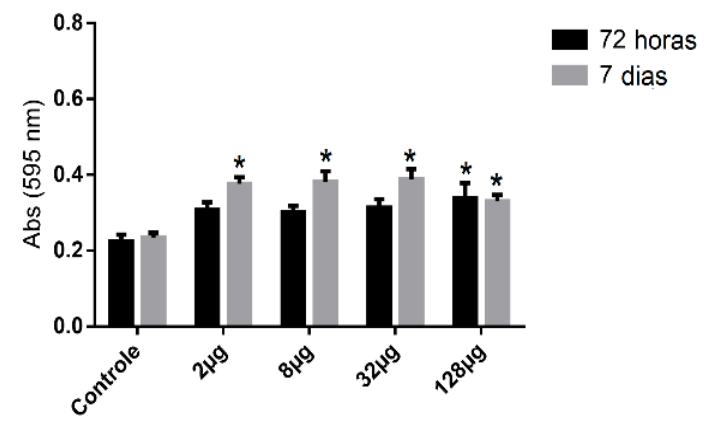

(E)

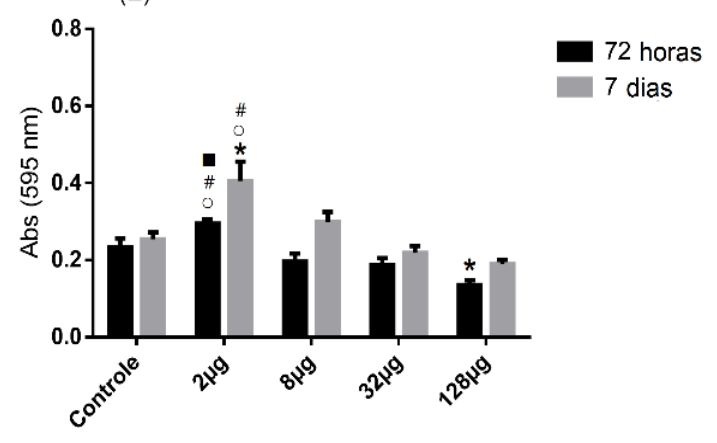

Figura 3: Citotoxicidade dos peptídeos clavanina A (A), clavanina MO (B), LL-37 (C) e controles

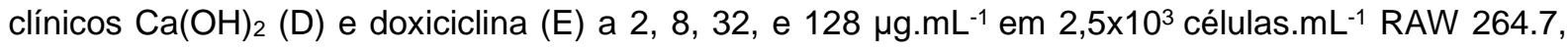
após $72 \mathrm{~h}$ e $7 \mathrm{~d}$, a partir do ensaio de MTT. As culturas foram estimuladas com $100 \mathrm{ng} \cdot \mathrm{mL}^{-1} \mathrm{de}$

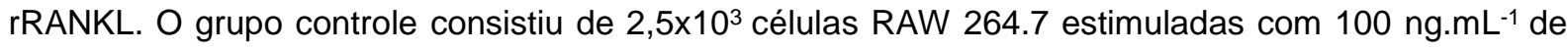
rRANKL. A viabilidade celular foi representada por media e erro padrão, na absorbância a $595 \mathrm{~nm}$, realizada em triplicata técnica e biológica. ${ }^{*} p<0,05$ comparando-se ao grupo controle, em cada condição testada. op<0,05 comparando-se aos grupos contendo $128 \mu \mathrm{g} \cdot \mathrm{mL}^{-1}$ de cada produto, em cada condição testada. \#p<0,05 comparando-se aos grupos contendo $32 \mu \mathrm{g} \cdot \mathrm{mL}^{-1}$ de cada produto, em cada condição testada. $\square \mathrm{p}<0,05$ comparando-se aos grupos contendo $8 \mu \mathrm{g} \cdot \mathrm{mL}^{-1}$ de cada produto, em cada condição testada. 


\subsection{PRODUÇÃO DE ÓXIDO NÍTRICO EM DIFERENTES CONCENTRAÇÕES DE PEPTÍDEOS E CONTROLES CLÍNICOS}

Por ser um importante mediador inflamatório no processo de osteoclastogênese, a produção de NO foi avaliada em todos os grupos e períodos experimentais. A produção de nitritos foi avaliada a partir dos sobrenadantes das culturas, avaliada pelo método de Green et al. (117), com adaptações. A produção de NO foi comparada a uma curva padrão de nitrito, com variações entre $200 \mu \mathrm{M}$ e 0,09 $\mu \mathrm{M}$. De maneira geral, o padrão da produção de NO manteve-se estável ou diminuído em comparação aos grupos controles (Figuras 4 e 5), com exceções somente na presença de baixas concentrações de doxiciclina ( 2 e $8 \mu \mathrm{g} \cdot \mathrm{mL}^{-1}$ ), nas culturas estimuladas com rRANKL, após $7 \mathrm{~d}(\mathrm{p}<0,05)$ (Figura 5E). Na presença dos peptídeos ou controles clínicos, em culturas de células RAW 264.7, foi observado uma redução na produção de NO, entre o grupo controle e os grupos na presença de clavanina $A$, em todas as concentrações testadas, no período experimental de 72 $\mathrm{h}(\mathrm{p}<0,05)$ e nas concentrações 128 e $32 \mu \mathrm{g} \cdot \mathrm{mL}^{-1}$, após $7 \mathrm{~d}(\mathrm{p}<0,05)$ (Figura 4A). Na presença da clavanina MO (Figura 4B) e LL-37 (Figura 4C), a produção de NO foi regulada negativamente nas concentrações de 2 e $8 \mu \mathrm{g} \cdot \mathrm{mL}^{-1}$, em $72 \mathrm{~h}(\mathrm{p}<0,05)$. Fato semelhante também foi observado no controle clínico representado pelo $\mathrm{Ca}(\mathrm{OH})_{2}$, na concentração de $8 \mu \mathrm{g} \cdot \mathrm{mL}^{-1}$, também após $72 \mathrm{~h}(\mathrm{p}<0,05)$ (Figura 4D). O outro controle clínico, a doxiciclina, nas concentrações de 8, 32 e $128 \mu \mathrm{g} \cdot \mathrm{mL}^{-1}$, apresentaram diminuição na produção de NO, após 7 d de cultura, em comparação ao grupo controle $(\mathrm{p}<0,05)$ (Figura $4 \mathrm{E})$.

De uma maneira generalizada, a adição de $100 \mathrm{ng} \cdot \mathrm{mL}^{-1}$ de $\mathrm{rRANKL}$ às culturas celulares de pré-osteoclastos RAW 264.7, levou a um aumento significativo na produção de NO (Figura 5). No entanto, nas culturas celulares estimuladas por rRANKL, o padrão de regulação negativa foi mantida na presença da clavanina $A$, em todas as concentrações, com a diminuição mais expressiva na concentração de $2 \mu \mathrm{g} \cdot \mathrm{mL}^{-1}$, após $72 \mathrm{~h}(\mathrm{p}<0,05)$ (Figura 5A). Essa diminuição também foi observada em todas as concentrações testadas de clavanina $M O$, após $72 \mathrm{~h}(\mathrm{p}<0,05)$ e nas concentrações de 32 e $128 \mu \mathrm{g} \cdot \mathrm{mL}^{-1}$, após $7 \mathrm{~d}(\mathrm{p}<0,05)$ (Figura 5B). A presença das concentrações de 8, 32 e $128 \mu \mathrm{g} \cdot \mathrm{mL}^{-1}$ de LL-37 também levaram a uma regulação negativa na produção de $\mathrm{NO}$, após $72 \mathrm{~h}(\mathrm{p}<0,05)$ (Figura $5 \mathrm{C})$. Essa regulação 
negativa, também pôde ser observada nas presença de 2, 8, 32, e $128 \mu \mathrm{g} \cdot \mathrm{mL}^{-1}$ de $\mathrm{Ca}(\mathrm{OH})_{2} \quad(\mathrm{p}<0,05)$, em $72 \mathrm{~h}$ (Figura 5D). Por último, a doxiciclina, levou a uma redução dos níveis de produção de NO unicamente na concentração de $128 \mu \mathrm{g} \cdot \mathrm{mL}^{-1}$, em $72 \mathrm{~h}(\mathrm{p}<0,05)$, entretanto, na presença de $2 \mu \mathrm{g} \cdot \mathrm{mL}^{-1}$, após $7 \mathrm{~d}$, verificou-se um aumento na produção de $\mathrm{NO}$ em relação a todas as concentrações testadas, incluindo o grupo de controle $(p<0,05)$ (Figura $5 E)$. 
(A)

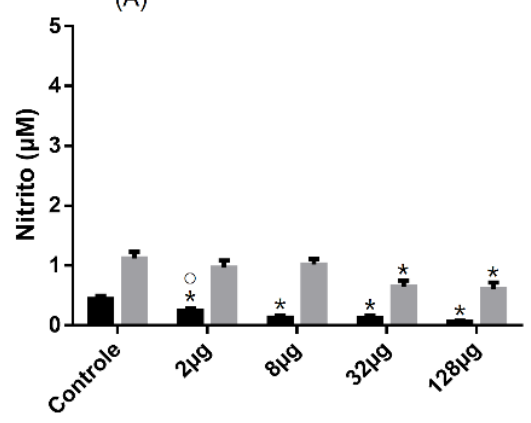

(C)

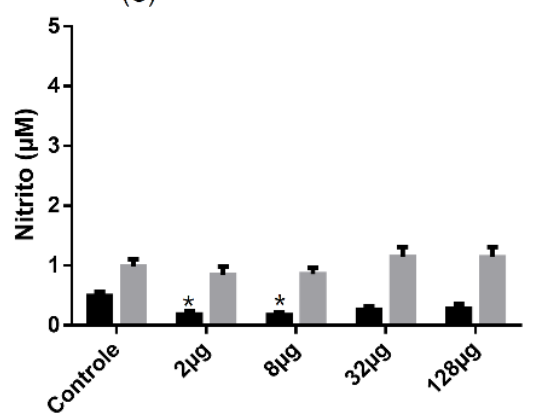

(B)

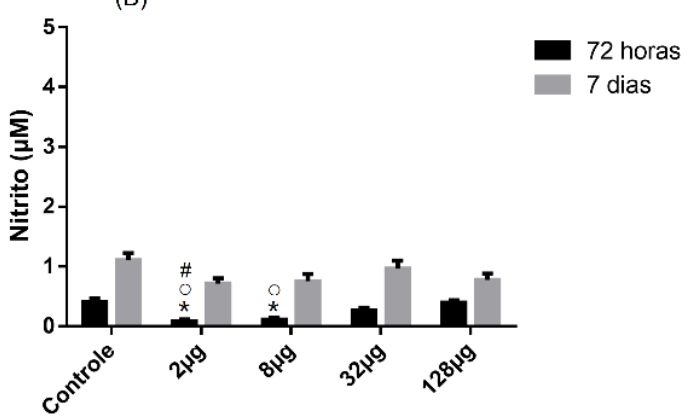

(D)

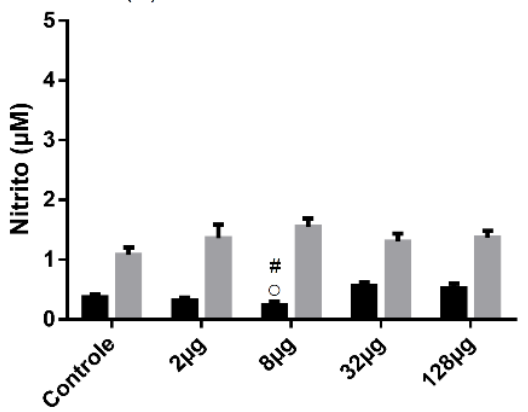

(E)

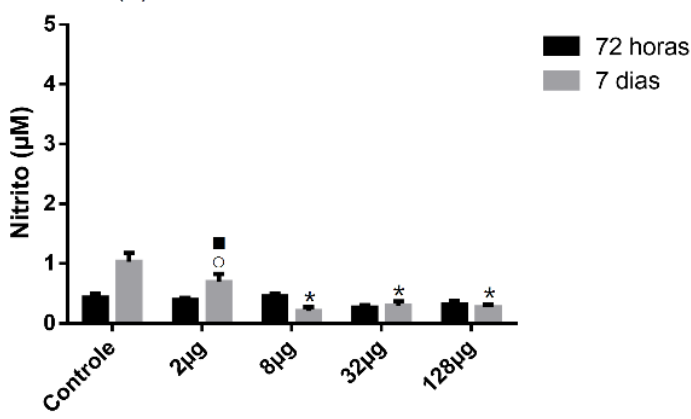

Figura 4: Produção de óxido nítrico na presença dos peptídeos clavanina $A(A)$, clavanina MO (B), LL$37(\mathrm{C})$ e controles clínicos $\mathrm{Ca}(\mathrm{OH})_{2}(\mathrm{D})$ e doxiciclina $(\mathrm{E})$ na concentração de 2, 8, 32, e $128 \mu \mathrm{g} \cdot \mathrm{mL}^{-1}$ em $2,5 \times 10^{3}$ células RAW 264.7, após $72 \mathrm{~h}$ e $7 \mathrm{~d}$, pelo método de Green et al., com adaptações. $\mathrm{O}$

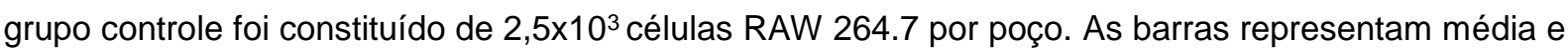
erro padrão, na absorbância a $490 \mathrm{~nm}$, realizadas em triplicata técnica e biológica. ${ }^{*} \mathrm{p}<0,05$ comparando-se ao grupo controle, em cada condição testada. $\circ p<0,05$ comparando-se aos grupos contendo $128 \mu \mathrm{g} \cdot \mathrm{mL}^{-1}$ de cada produto, em cada condição testada. \#p<0,05 comparando-se aos grupos contendo $32 \mu \mathrm{g} \cdot \mathrm{mL}^{-1}$ de cada produto, em cada condição testada. $\square \mathrm{p}<0,05$ comparando-se aos grupos contendo $8 \mu \mathrm{g} \cdot \mathrm{mL}^{-1}$ de cada produto, em cada condição testada. 
(A)

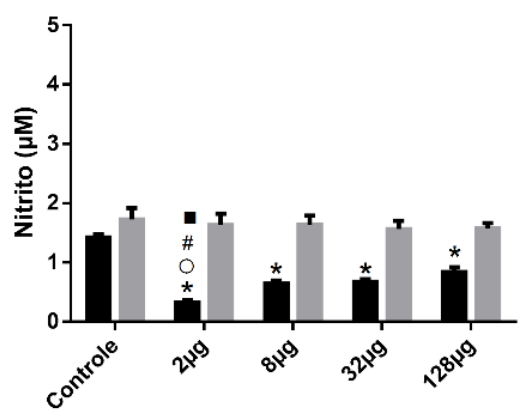

(C)

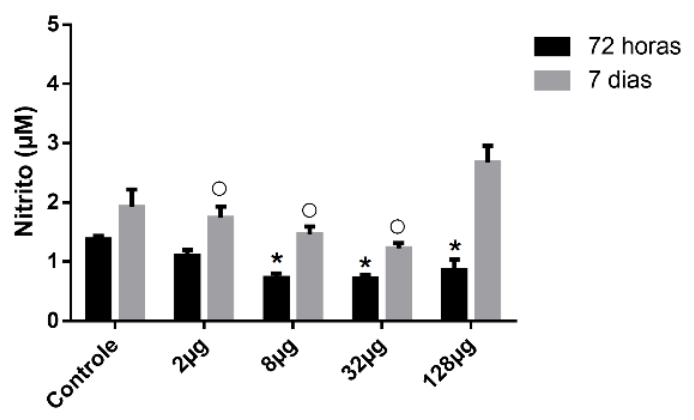

(B)

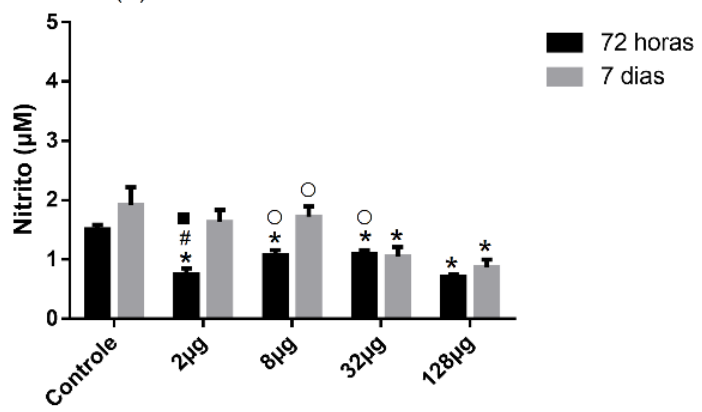

(D)

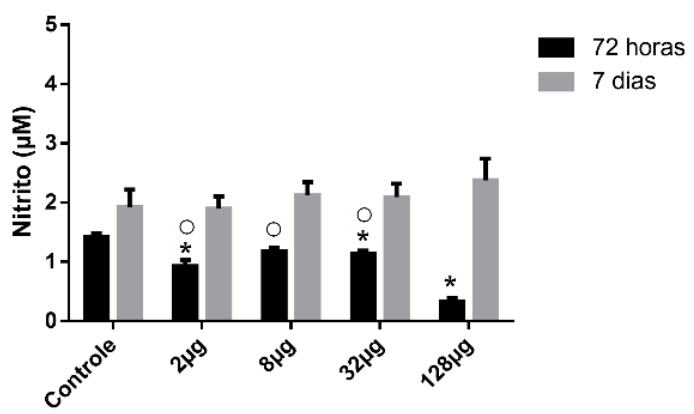

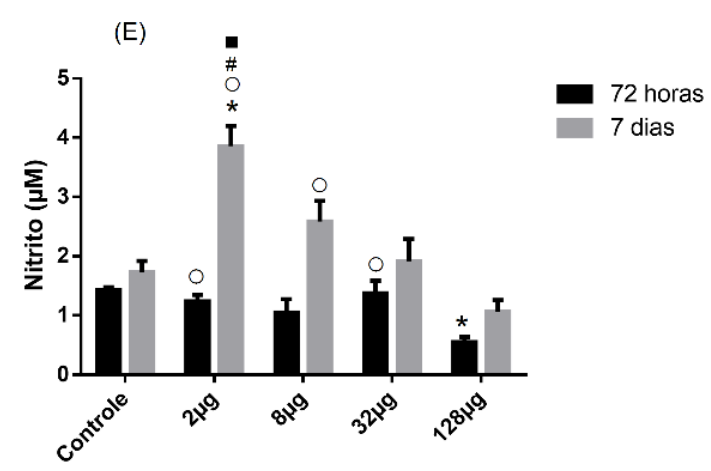

Figura 5: Produção de óxido nítrico na presença dos peptídeos clavanina $A(A)$, clavanina MO (B), LL37 (C) e controles clínicos $\mathrm{Ca}(\mathrm{OH})_{2}(\mathrm{D})$ e doxiciclina (E) na concentração de 2, 8, 32 e $128 \mu \mathrm{g} \cdot \mathrm{mL}^{-1}$ em $2,5 \times 10^{3}$ células RAW 264.7 e estimuladas com $100 \mathrm{ng} \cdot \mathrm{mL}^{-1}$ de rRANKL por poço, após $72 \mathrm{~h}$ e $7 \mathrm{~d}$,

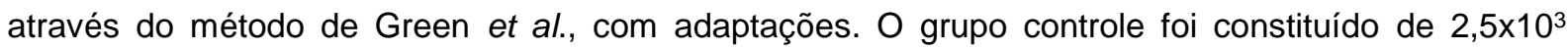
células RAW 264.7 por poço, estimuladas com $100 \mathrm{ng} \cdot \mathrm{mL}^{-1}$ de rRANKL. As barras representam média e erro padrão, na absorbância de $490 \mathrm{~nm}$, realizadas em triplicata técnica e biológica. ${ }^{*} \mathrm{p}<0,05$ comparando-se ao grupo controle, em cada condição testada. $\circ p<0,05$ comparando-se aos grupos contendo $128 \mu \mathrm{g} \cdot \mathrm{mL}^{-1}$ de cada produto, em cada condição testada. \#p<0,05 comparando-se aos grupos contendo $32 \mu \mathrm{g} \cdot \mathrm{mL}^{-1}$ de cada produto, em cada condição testada. $\square \mathrm{p}<0,05$ comparando-se aos grupos contendo $8 \mu \mathrm{g} \cdot \mathrm{mL}^{-1}$ de cada produto, em cada condição testada. 


\subsection{OSTEOCLASTOGÊNESE MEDIADA POR IRANKL EM DIFERENTES CONCENTRAÇÕES DE PEPTÍDEOS E CONTROLES CLÍNICOS}

Após 7 d de incubação, foi realizada a avaliação do número de osteoclastos diferenciados em cultura de células RAW 264.7 estimuladas com rRANKL, seguida de coloração de fosfatase ácida tartarato resistente (TRAP). Para a contagem do número de osteoclastos, foram consideradas as células TRAP positivas (com coloração vermelho / laranja) com mais de três núcleos corados em seu interior, como osteoclastos multinucleados (Figura 6). Por ser expressa em altos níveis nos osteoclastos, a TRAP foi utilizada como marcador citoquímico para osteoclastos e seus precursores. O número de osteoclastos em cultura na presença dos peptídeos antimicrobianos clavanina A, clavanina MO e LL-37, além dos controles clínicos $\mathrm{Ca}(\mathrm{OH})_{2}$ e doxiciclina foi comparado ao grupo controle (células RAW 264.7 estimulados com $100 \mathrm{ng} \cdot \mathrm{mL}^{-1}$ de rRANKL). Observou-se de uma maneira geral, que todas as concentrações testadas de todos os produtos testados causaram redução na osteoclastogênese mediada por rRANKL $(p<0,05)$ (Figura 7$)$.

Em todas as concentrações testadas $\left(2,8,32\right.$, e $\left.128 \mu \mathrm{g} \cdot \mathrm{mL}^{-1}\right)$, o peptídeo antimicrobiano clavanina $A$ reduziu a osteoclastogênese em uma proporção inversa à sua concentração $(p<0,05)$, ou seja, quanto maior a concentração, menor o número de osteoclastos diferenciados (Figura 7A). Entre as concentrações testadas de clavanina $\mathrm{MO}$, a osteoclastogênese também foi reduzida, de forma semelhante entre elas $(p<0,05)$ (Figura 7B). A LL-37 apresentou redução na osteoclastogênese em todas as concentrações testadas, entretanto, destacando-se as concentrações de 8 e $128 \mu \mathrm{g} \cdot \mathrm{mL}^{-1}(\mathrm{p}<0,05)$ (Figura $7 \mathrm{C}$ ), que apresentaram o menor número de osteoclastos diferenciados (4 e 2 em média, respectivamente). $\mathrm{O} \mathrm{Ca}(\mathrm{OH})_{2}$ reduziu a osteoclastogênese em todos as concentrações testadas $(p<0,05)$, sendo $8 \mu \mathrm{g} \cdot \mathrm{mL}^{-1} \mathrm{a}$ concentração mais eficiente, representada por um total de 5 osteoclastos diferenciados, em média (Figura 7D). A avaliação da osteoclastogênese na medicação doxiciclina, apresentou um grau de redução proporcional à concentração testada, ou seja, quanto maior a concentração, maior a inibição da diferenciação de osteoclastos. Nesse caso, a concentração de $128 \mu \mathrm{g} \cdot \mathrm{mL}^{-1}$ apresentou significativa maior redução na diferenciação de osteoclastos (Figura 7E). 

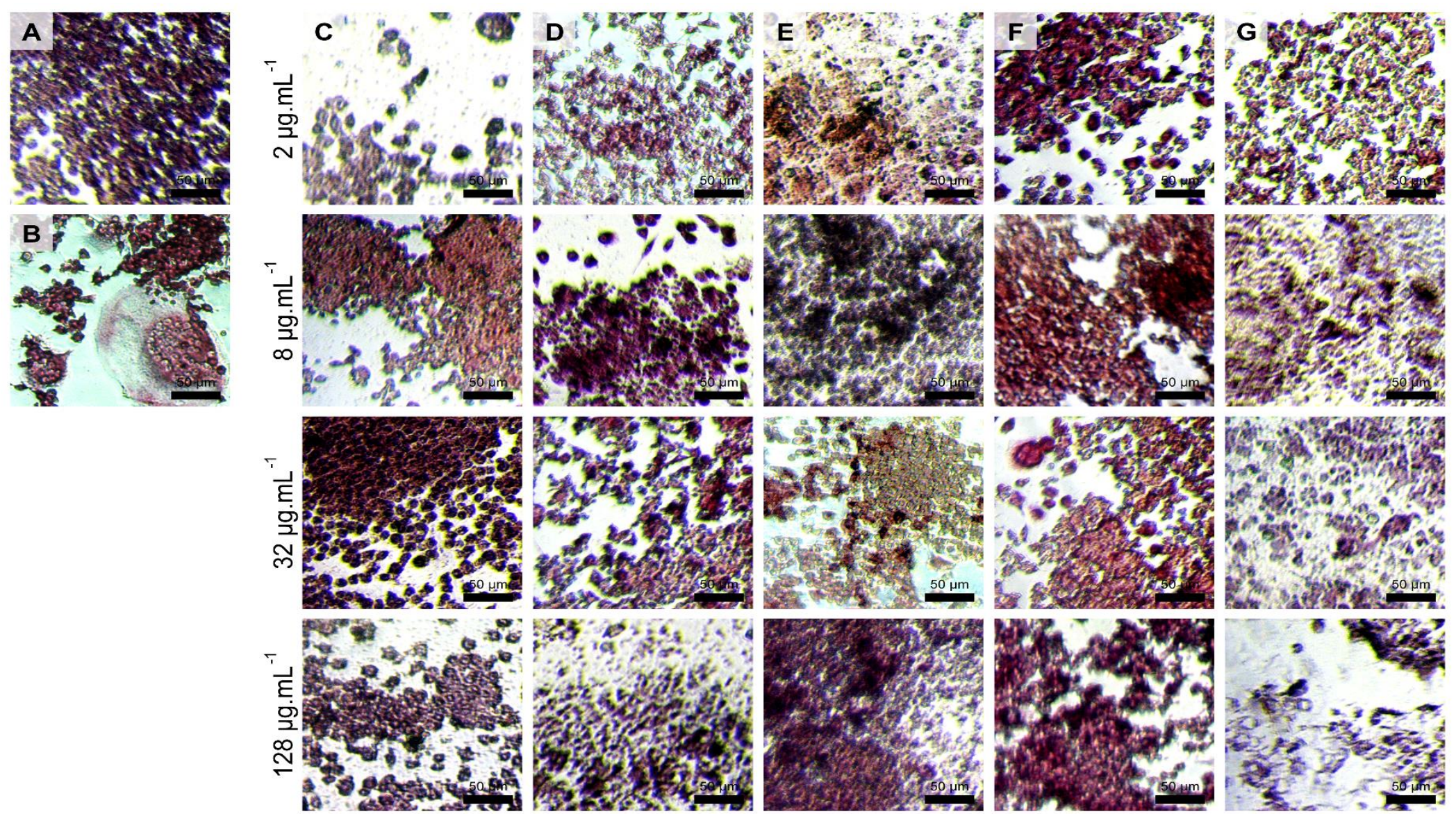

Figura 6: Culturas celulares representadas por fotografias após a coloração de TRAP de cada concentração testada, após 7 d de cultura. $O$ primeiro grupo

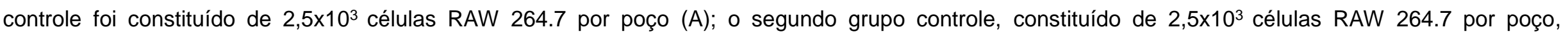

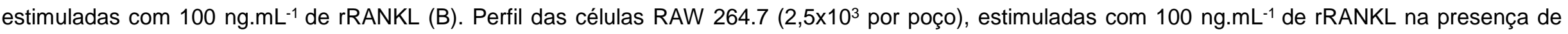
clavanina $A(C)$, clavanina MO (D), LL-37 (E) e controles clínicos $\mathrm{Ca}(\mathrm{OH})_{2}(\mathrm{~F})$ e doxiciclina $(\mathrm{G})$ na concentração de 2, 8, 32, e $128 \mu \mathrm{gg} \mathrm{mL}^{-1}$ (respectivamente indicado nas colunas). 
(A)

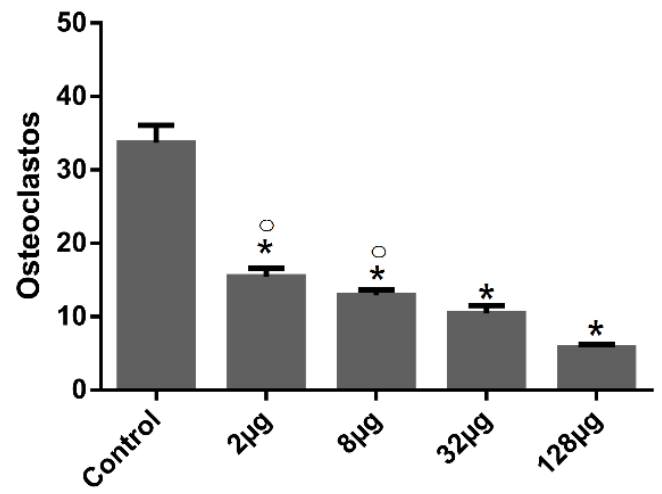

(C)

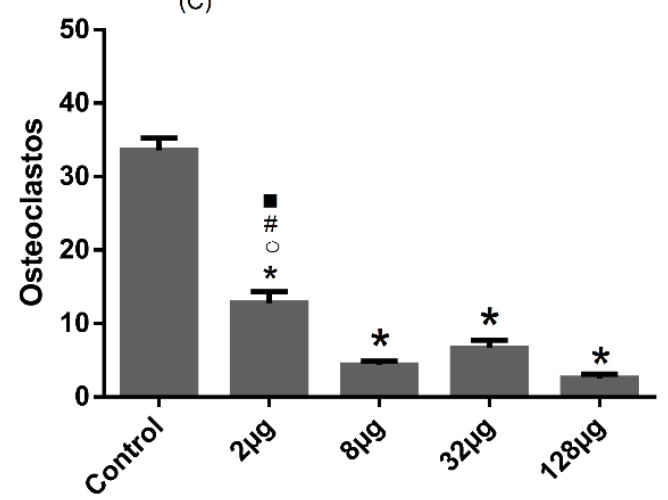

(B)

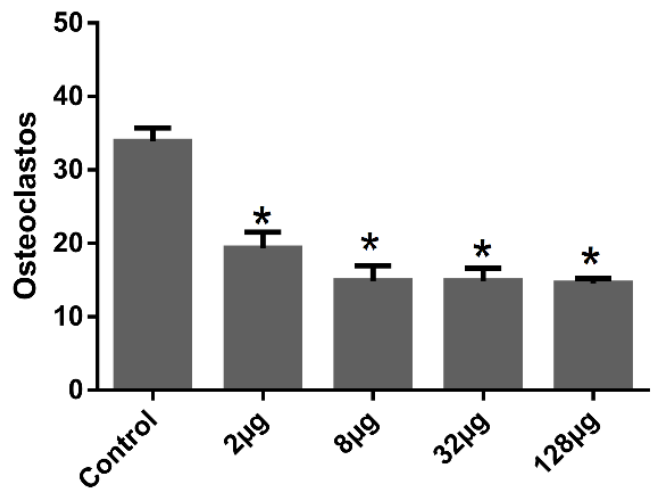

(D)

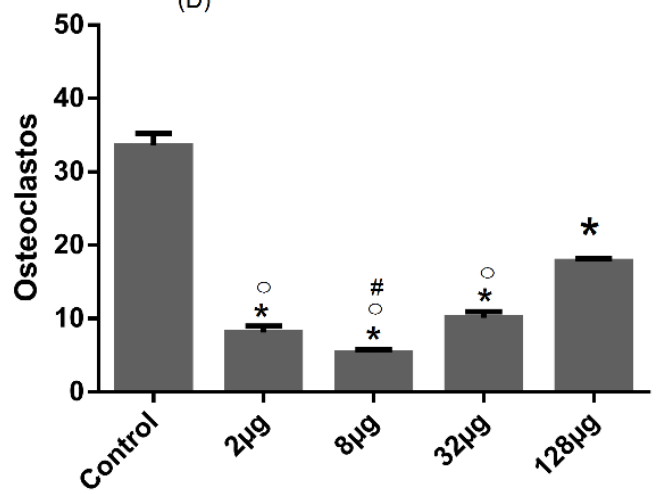

(E)

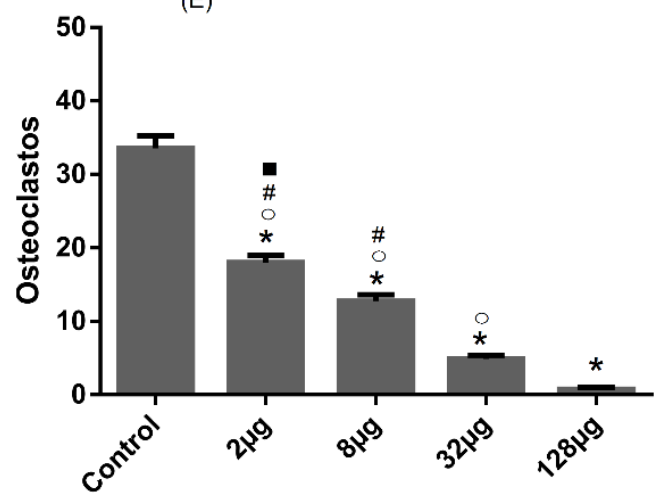

Figura 7: Número de osteoclastos diferenciados na presença de clavanina $A(A)$, clavanina $M O(B)$, LL-37 (C) e controles clínicos $\mathrm{Ca}(\mathrm{OH})_{2}$ (D) e doxiciclina (E) nas concentrações de 2, 8, 32, e 128

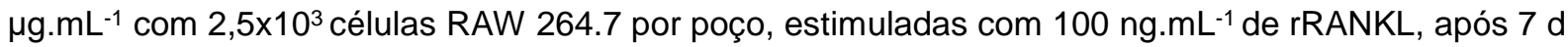
de incubação, seguido de coloração de TRAP. O grupo controle foi representado por $2,5 \times 10^{3}$ células RAW 264.7 por poço estimuladas com $100 \mathrm{ng} \cdot \mathrm{mL}^{-1}$ de rRANKL. O número de osteoclastos foi representado por média e erro padrão, realizados em triplicata técnica e biológica. ${ }^{*} p<0,05$ comparando-se ao grupo controle, em cada condição testada. $o p<0,05$ comparando-se aos grupos contendo $128 \mu \mathrm{g} \cdot \mathrm{mL}^{-1}$ de cada produto, em cada condição testada. \#p<0,05 comparando-se aos grupos contendo $32 \mu \mathrm{g} \cdot \mathrm{mL}^{-1}$ de cada produto, em cada condição testada. $\square \mathrm{p}<0,05$ comparando-se aos grupos contendo $8 \mu \mathrm{g} \cdot \mathrm{mL}^{-1}$ de cada produto, em cada condição testada. 


\subsection{ANÁLISE COMPARATIVA DA MENOR CONCENTRAÇÃO COMUM ENTRE OS PEPTÍDEOS E OS CONTROLES CAPAZ DE REDUZIR A OSTEOCLASTOGÊNESE}

A partir dos resultados da contagem de osteoclastos diferenciados em cultura de células RAW 264.7 estimuladas com rRANKL, após coloração de TRAP, foi eleita a concentração que apresentou maior redução da osteoclastogênese. Observou-se que a concentração de $8 \mu \mathrm{g} \cdot \mathrm{mL}^{-1}$, foi a menor concentração comum aos peptídeos e controles clínicos, capaz de reduzir a diferenciação de osteoclastos (Figura 8). Dessa forma, ao considerar a concentração de $8 \mu \mathrm{g} \cdot \mathrm{mL}^{-1}$ de cada peptídeo e controle clínico, notou-se que os melhores resultados de redução da osteoclastogênese foram apesentados pelo peptídeo LL-37 e pelo controle clínico $\mathrm{Ca}(\mathrm{OH})_{2}$. A LL-37 apresentou aproximadamente $33 \%$ dos osteoclastos diferenciados comparados aos grupos dos peptídeos clavanina A, clavanina $\mathrm{MO}$ e do controle clínico doxiciclina. Já o controle clínico $\mathrm{Ca}(\mathrm{OH})_{2}$, demonstrou um total de $41 \%$ de osteoclastos diferenciados, comparado a esses mesmos grupos. Nesse caso, esses produtos apresentaram maior redução da osteoclastogênese quando comparado às mesmas concentrações de clavanina $A$, clavanina MO e doxiciclina $(p<0,0001)$. 


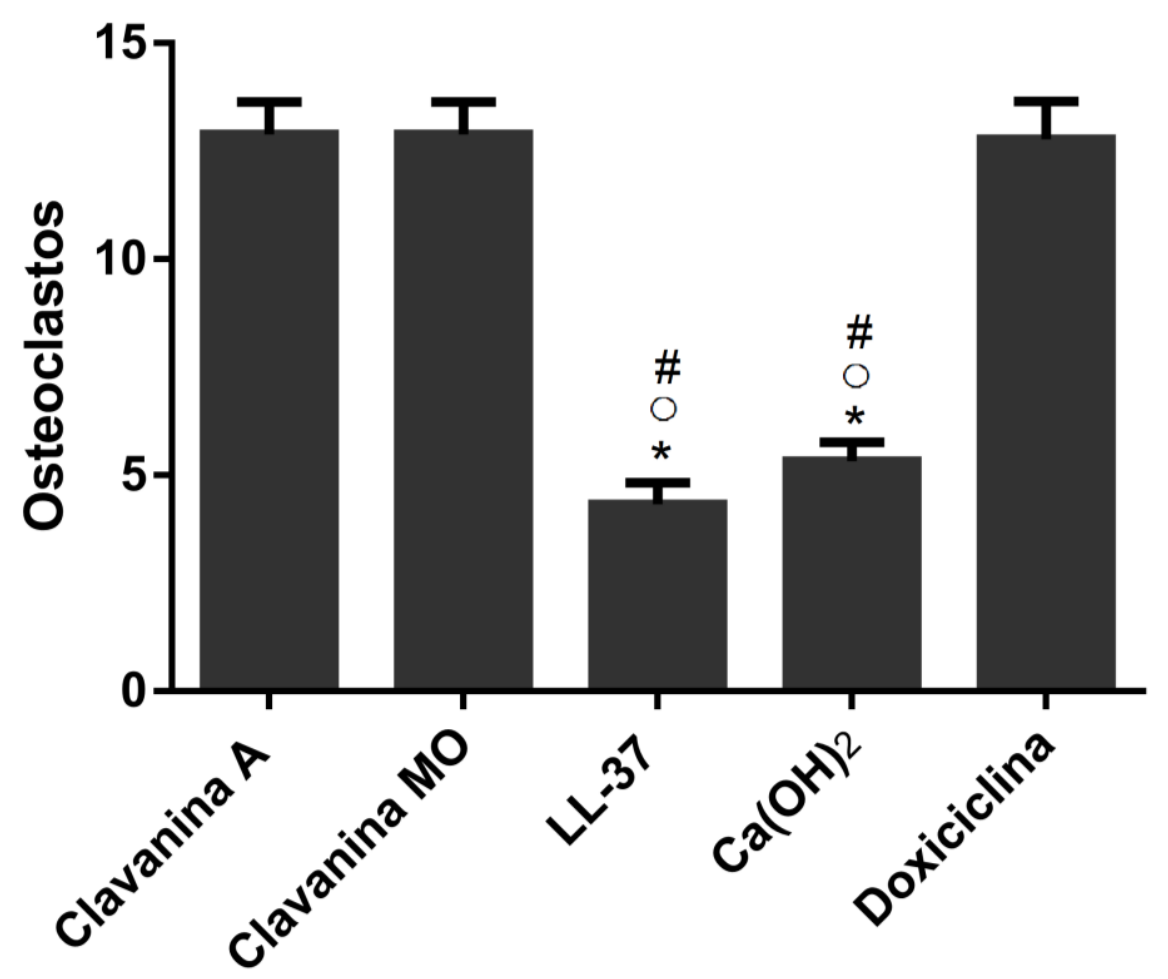

Figura 8: Concentração de $8 \mu \mathrm{g} \cdot \mathrm{mL}^{-1}$ dos peptídeos clavanina A, clavanina MO, LL-37 e controles

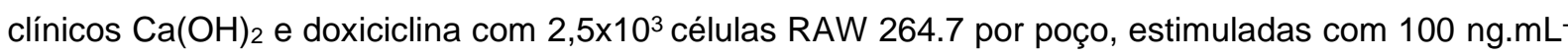
${ }^{1}$ de rRANKL, após 7 d de incubação, seguido de coloração de TRAP. O número de osteoclastos foi representado por média e erro padrão, realizados em triplicata técnica e biológica. ${ }^{*} \mathrm{p}<0,0001$ comparando-se à clavanina $\mathrm{A}$, em cada grupo testado. $\mathrm{op}<0,0001$ comparando-se à clavanina $\mathrm{MO}$ em cada grupo testado. \#p<0,0001 comparando-se à doxiciclina em cada grupo testado. 


\section{DISCUSSÃO}

O estabelecimento do processo de reabsorção óssea em lesões perirradiculares e na periodontite, muitas vezes, leva à dificuldade no tratamento dessas patologias, em virtude de uma terapia não específica e eficaz contra essa condição óssea. O agravamento da patologia pulpar e perirradicular, bem como da periodontite, pode levar ao comprometimento do elemento dentário e sua estrutura de suporte, podendo resultar além da perda dentária, no aumento do índice de edentulismo da população e nos riscos às patologias sistêmicas $(7,65)$. Essas doenças podem ser essencialmente caracterizadas pela perda óssea excessiva devido à alta quantidade/atividade dos osteoclastos. Os osteoclastos, por sua vez, podem ser células especializadas que comumente derivam-se de uma linhagem hematopoiética de monócitos/macrófagos, responsáveis pela reabsorção óssea.

No caso das lesões pulpares, o tratamento endodôntico efetivo pode ter, como objetivo, a eliminação de microrganismos presentes no canal radicular, a cura da lesão e a regeneração dos tecidos perirradiculares. No entanto, em muitos casos a instrumentação químico-mecânica pode ser insuficiente para desinfeção completa do sistema de canais radiculares, devido à sua complexidade anatômica. Portanto, a medicação intracanal pode complementar o trabalho da instrumentação e da irrigação, podendo apresentar a capacidade de reduzir as bactérias remanescentes e dar suporte à cicatrização dos tecidos periapicais (119), para posterior preenchimento dos condutos com material obturador.

Assim como no tratamento endodôntico, as terapias para a doença periodontal, buscam a erradicação dos microrganismos aderidos aos tecidos de suporte e a regeneração dos tecidos periodontais. Para tanto, esse tratamento pode ser viabilizado pela raspagem e alisamento corono-radicular, isoladamente; ou associada a um tratamento químico, como uso de antibióticos sistêmicos e locais; aliada a enxaguantes bucais com efeito antibacteriano; ou ainda, aliada a terapia fotodinâmica. Nesse sentido, também podem ser incluídos, dependendo do caso clínico, o tratamento cirúrgico da periodontite, com procedimentos como gengivectomia, reparação óssea alveolar, entre outros. Além disso, a terapia periodontal de suporte, pode apresentar-se como uma forma de manutenção ao 
tratamento periodontal cirúrgico ou não-cirúrgico, dependendo de parâmetros clínicos de recolonização para que ele seja efetivo a longo prazo (120).

Dessa forma, diversas terapias têm sido propostas para ambos os tipos de reabsorções ósseas de origem dentárias. No entanto, as terapias atuais ainda podem apresentar algum tipo de limitação. Na maior parte delas, essas limitações podem incluir a ausência de atividades antimicrobianas, imunomodulatórias e reparadoras, podendo, ainda, promover danos ao indivíduo. Além disso, evidências apontam resistência antimicrobiana à diversas medicações utilizadas nessas terapias, por essa razão, motiva-se a busca por novas abordagens terapêuticas. $O$ presente estudo avaliou a produção de NO, capacidade citotóxica e inibitória na osteoclastogênse na presença de peptídeos de defesa do hospedeiro. Esses foram contrastados com os dados do $\mathrm{Ca}(\mathrm{OH})_{2}$ e da doxiciclina, medicações comumente utilizadas na endodontia e periodontia, respectivamente. A finalidade deste estudo consistiu em avaliar o potencial dessas biomoléculas como possíveis candidatos a novas medicações intracanais ou medicações para uso na doença periodontal. $O$ $\mathrm{Ca}(\mathrm{OH})_{2}$ e a doxiciclina foram eleitos como controles clínicos, mediante testes prévios. Inicialmente foram avaliados possíveis candidatos a controle clínico in vitro. O objetivo foi associar aos experimentos, algum produto comumente utilizado no contexto clínico durante tratamento endodôntico e periodontal. Para o foco periodontal, inicialmente testou-se a clorexidina em diferentes concentrações (dados não apresentados), porém mesmo as menores concentrações testadas in vitro foram citotóxicas às células RAW 264.7, inviabilizando a realização de estudos in vitro com contato direto com a clorexidina. Por outro lado, este produto tem sido amplamente utilizado clinicamente, pois seu uso tem sido restrito a curtos períodos de tempo em comparação com o experimento testado in vitro. Deste modo, as concentrações de clorexidina em enxaguantes bucais podem ser diluídas em fluidos bucais, evitando grandes efeitos adversos ao usuário. O segundo candidato para controle clínico periodontal foi a doxiciclina, que apresentou melhores resultados de viabilidade celular e produção de NO e assim, foi eleita como um controle clínico, para o contexto periodontal. Para o controle clínico, no contexto endodôntico foi considerado o $\mathrm{Ca}(\mathrm{OH})_{2}$. Trabalhos prévios do grupo utilizando a concentração de $128 \mu \mathrm{g} \cdot \mathrm{mL}^{-1}$ de $\mathrm{Ca}(\mathrm{OH})_{2}$ encontraram uma viabilidade celular semelhante ao controle de células RAW 264.7, apesar de também ter sido observado que a 
concentração inibitória mínima desta medicação para E. faecalis (1024 $\left.\mu \mathrm{g} \cdot \mathrm{mL}^{-1}\right)$ promoveu viabilidade celular nula (7).

Nesse sentido, foi proposto o uso de peptídeos de defesa do hospedeiro (PDHs) neste estudo, com a finalidade de avaliar o potencial dessas biomoléculas no contexto odontológico. Dessa forma, os PDHs apresentam-se como compostos relativamente pequenos (12-50 resíduos de aminoácidos). Em adição, os PDHs podem ser classificadas de acordo com sua conformação estrutural tridimensional. Em sua maioria, eles podem ser ricos em resíduos de aminoácidos hidrofóbicos, catiônicos ou anfipáticos (121). Desse modo, os PDHs podem apresentar ação direta contra microrganismos e podem ter atividades relacionadas com a imunidade inata. Tais atividades podem incluir a indução ou modulação de citocinas próinflamatórias e a produção de quimiocinas; a quimiotaxia, a apoptose, a inibição da resposta inflamatória, recrutamento, e estimulação da proliferação de macrófagos, neutrófilos, eosinófilos, a ativação dos linfócitos $\mathrm{T}$, e a diferenciação das células dendríticas. Além disso, os PDHs apresentam-se como uma proposta terapêutica por não serem tóxicas, de maneira geral, em células de mamíferos $(107,121)$ e por esses motivos, vêm sendo alvo de várias pesquisas para o desenvolvimento de novos fármacos.

Na odontologia, há alguns estudos que correlacionam peptídeos e infecções orais, incluindo peptídeos orais, neuropeptídeos, além de peptídeos oriundos de bactérias, peixes, bovinos e sintéticos. Diversos peptídeos já foram descritos na literatura; desses, pelo menos 45 PDHs diferentes estão presentes no ambiente oral, derivados de saliva e de fluido gengival. Como exemplo, encontram-se as $\alpha$ e $\beta$ defensinas (expressas no epitélio gengival e glândulas e ductos salivares), LL-37, histatina e peptídeos derivados de lactoferrina. Os neutófilos podem expressar vários outros peptídeos, como as a-defensinas (no fluido crevicular) e ainda a LL-37 (no epitélio inflamado, glândulas submandibulares e saliva). Esses diferentes peptídeos podem apresentar atividade sinérgica a outros PDHs e participam da defesa na saliva, com uma atividade de co-expressão (21). Um estudo recente fez um levantamento de trabalhos que utilizaram peptídeos com potencial na odontologia, especialmente na terapia endodôntica. Os resultados revelaram que, o peptídeo p53 22-mer (de tumor supressor de proteína) demonstrou ser efetivo contra carcinoma oral de células escamosas. Já a nisina, derivada de Lactococcus lactis geralmente com atividade contra bactérias Gram-positivas, demonstrou potencial na 
terapia endodôntica. Sua ação pode ocorrer através da interação com a membrana fosfolipídica, induzindo o extravasamento celular, no entanto, seu mecanismo de ação ainda é discutido. Estudos acerca da nisina como uma medicação intracanal apresentaram resultados semelhantes a $\mathrm{Ca}(\mathrm{OH})_{2}$. A $\beta$-defensina humana 3 , estudada com aplicação na terapia endodôntica, demonstrou melhor performance antimicrobiana comparada ao $\mathrm{Ca}(\mathrm{OH})_{2}$ e a clorexidina. A $\beta$-defensina humana 3 pode apresentar propriedades antibacterianas, antiendotoxinas e imunomodulatória, baseado em sua baixa citotoxicidade para células. As $\beta$-defensinastambém demonstram potencial contra herpes vírus simplex e cárie (21).

Peptídeos sintéticos podem superar as limitações de baixa estabilidade e meia vida curta, presente nos naturais. Ainda com finalidade endodôntica, foram testados 10 PDHs sintéticos contra Streptococcus milleri. Entre os peptídeos usados, os peptídeos de neutrófilos humanos histatina 8, cecropina P1 e magainina, não inibiram nenhuma das cepas testadas. Por outro lado, outros peptídeos inibiram 10\% (histatina 5), 30\% (cecropina B), 91\% (indolicidina) e 95\% (magainina amida) do desenvolvimento de Streptococcus milleri (21). Além disso, alguns microrganismos endodônticos podem ser capazes de produzir peptídeos, tais como Pseudomonas spp., que podem produzir o peptídeo PsVP-10. Esse peptídeo pode ser capaz de inibir o crescimento de muitas bactérias Gram-positivas e Gramnegativas, e ainda pode apresentar resistência ao calor, alterações de $\mathrm{pH}$ e enzimas proteolíticas. Um dos estudos acerca desse peptídeo, relatou que todas as cepas de E. faecalis, a partir de isolados clínicos foram sensíveis à PsVP-10. Outro ponto importante para infecções endodônticas pode ser a existência de um biofilme em todo o sistema de canais radiculares. Ainda sobre esse tema, os estudos demonstraram que os PDHs ribonuclease 7 e psoriasina, expressos por células epiteliais gengivais, podem ser ativos contra biofilmes orais (21).

Muitos estudos também avaliaram a atividade de PDHs contra microrganismos presentes em cáries e doenças periodontais. A histatina, por exemplo, demonstrou ser efetiva contra gengivite. As bactérias presentes na doença periodontal foram suscetíveis à atividade antimicrobiana da LL-37, enquanto bactérias presentes em cáries, à atividade antimicrobiana de $\beta$-defensina 2 . Os peptídeos humanos adrenomedulina e $\beta$-defensinas apresentaram potencial terapêutico na doença periodontal. Além disso, o peptídeo intestinal vasoativo do microambiente linfoide foi associado com uma possível diminuição da resposta 
inflamatória e a inibição da reabsorção de osso alveolar em experimentos com periodontite (21). Outros estudos demonstraram que a LL-37 pode exibir dupla função, incluindo bactericida e neutralizando o LPS de bactérias Gram-negativas (5, 122). Este PDH pode ser parcialmente inibido pela saliva. Por outro lado a saliva pode proteger a LL-37 da inativação proteolítica por proteases secretadas pelo patógeno periodontal $P$. gingivalis. Uma outra forma de ação dos PDHs pode ser por meio de aglutinação bacteriana ou adesão. Muitos PDHs podem agir dessa maneira, como é o caso da fibronectina, que pode ser expressa em hepatócitos e células epiteliais e estar presente na saliva. Dessa forma, a fibronectina pode desempenhar um papel na redução da aderência de bactérias às superfícies orais. Em adição, a fibronectina também pode se ligar diretamente a fimbrilina de $P$. gingivalis e, assim, pode inibir a expressão induzida por fimbrilina de citocinas inflamatórias em macrófagos. Os baixos níveis de fibronectina foram correlacionados com elevados níveis de Streptococcus mutans em crianças e a periodontite aparentemente pode estar associada com uma relativa falta de fibronectina em adultos (5).

Diante da análise desses trabalhos, além de diversos outros, incluindo estudos prévios do nosso grupo, foram definidos os peptídeos de defesa do hospedeiro utilizados nesse estudo: a clavanina A, a clavanina MO e a LL-37. A seleção desses três peptídeos, foi motivada por se tratarem de possíveis biomoléculas ativas contra infecções $(7,99)$. Estudos apontaram que os PDHs de maneira geral, podem apresentar atividade de amplo espectro, podendo incluir múltiplos mecanismos de ação, além de atividade antimicrobiana e imunomodulatória, em baixas concentrações (85). Embora um trabalho anterior do grupo, realizado com estes mesmos peptídeos, não tenha encontrado boa atividade antimicrobiana, os PDHs clavanina A, clavanina MO e LL-37 apresentaram boa resposta antiinflamatória, e sugerindo ainda indícios na redução da osteoclastogênese (7). Desse modo, esses últimos resultados obtidos estabeleceram-se como parâmetro para análise neste estudo.

Além disso, por meio desse trabalho in vitro, foi possível avaliar parâmetros que se aproximam à realidade do organismo humano. Dessa maneira, foram estritamente estabelecidos fatores importantes, como a concentração de $\mathrm{CO}_{2}$, umidade, temperatura, $\mathrm{pH}$, entre outros. Para esse estudo, foi utilizada a linhagem de células RAW 264.7, que são monócito/macrófagos retirados de camundongo BALB/c após a indução de leucemia viral, que podem ser consideradas células pré- 
osteoclásticas (123). Os monócitos / macrófagos podem se diferenciar em osteoclastos multinucleados. Desse modo, existem dois tipos mais conhecidos de células capazes de se diferenciar em osteoclastos, os monócitos retirados da medula óssea (10) e a linhagem de células pré-osteoclásticas RAW 264.7 (28). A diferenciação pode ocorrer pela ação do fator de estimulação de colônias de macrófagos (M-CSF) e pelo RANKL (10). RAW 264.7 pode ser capaz de produzir seu próprio M-CSF (16). Por outro lado, os monócitos da medula óssea, necessitam deste estímulo de forma exógena (10). Um outro estímulo que pode induzir o processo de reabsorção óssea consiste na vitamina $D$. Trabalhos apontam que a vitamina $\mathrm{D}$ pode atuar na diferenciação de monócitos oriundos da medula óssea, em osteoclastos (124)

Como mencionado anteriormente, a escolha da linhagem celular RAW 264.7 para este trabalho, se deu por suas características de capacidade de se diferenciar em osteoclastos, além da otimização do trabalho, por ela ser capaz de produzir seu próprio M-CSF. Em adição, o estímulo com recombinante (r) RANKL mimetiza situações clínicas de maneira mais fiel. A atividade dos osteoclastos pode ser iniciada pela estimulação do RANKL, que pode induzir a secreção de prótons e enzimas líticas no vacúolo de reabsorção formado entre a superfície basal do osteoclasto e a superfície óssea. A acidificação destes compartimentos pela secreção dos prótons pode levar a ativação das enzimas fosfatase ácida tartarato resistente (TRAP) e catepsina $\mathrm{K}$ (CATK), que têm sido descritas como as principais enzimas responsáveis pela degradação do osso mineral e das matrizes de colágeno, levando a reabsorção óssea (125).

Dessa forma, dentro do nosso estudo, as culturas celulares foram caracterizadas em relação à viabilidade celular, à produção de $\mathrm{NO}$ e ao número de osteoclastos diferenciados. Para as análises de viabilidade celular, o teste escolhido foi o MTT. O ensaio colorimétrico de MTT permite avaliação da viabilidade celular através da análise da atividade da enzima desidrogenase mitocondrial em reduzir o sal brometo de 3-(4,5-dimetilazol-2-il)-2,5-difenil tetrazólio, no produto formazan (115). O teste de MTT foi escolhido com a finalidade de avaliar a citotoxicidade dos produtos testados. Para a avaliação da biocompatibilidade de um material, a citotoxicidade pode ser um dos parâmetros. A biocompatibilidade de um material pode ser refletida como o desempenho eficiente e não prejudicial ao hospedeiro, podendo induzir uma resposta vantajosa e apropriada durante o seu uso clínico. 
Dessa maneira, a citotoxicidade pode ser definida como a capacidade de afetar a viabilidade celular, determinada por inibição de seu crescimento ou lise celular, no contexto da biocompatibilidade (126).

Um outro parâmetro avaliado foi a produção celular de óxido nítrico, descrito na literatura como um provável regulador de diversas funções no organismo, como a produção de citocinas pró-inflamatórias e a osteoclastogênese. Nesse sentido, baixas concentrações de NO têm demonstrado potencialização na reabsorção óssea induzida por IL-1, fato baseado nas observações de que inibidores de NOS suprimiram a reabsorção óssea in vitro induzida por IL-1. A produção constitutiva de NO intrínseco dos osteoclastos, tem sido sugerida como essencial na função normal deles. Sugerem ainda, que a via iNOS tem um papel importante no curso da perda óssea que pode ser induzida por citocinas e inflamação (127). Assim, a literatura pertinente relata que em baixas concentrações, o NO aumenta a atividade dos osteoclastos estimulando o processo de reabsorção óssea (57), embora altas concentrações apresentem efeito inibitório na formação e atividade dos osteoclastos, podendo induzir a apoptose de pré-osteoclastos $(127,128)$. Além disso, o NO pode regular a síntese de OPG e RANKL em células da medula óssea (129).

Por fim, foram contabilizados o número de osteoclastos diferenciados em cultura após estímulo com rRANKL, na presença e na ausência dos peptídeos e controles clínicos. A contagem do número de osteoclastos foi realizada após coloração de TRAP. Foram considerados como osteoclastos as células TRAP positivas com mais de três núcleos em seu interior. Para esta análise foi utilizado um marcador citoquímico para osteoclastos, a enzima TRAP. Essa enzima pode estar envolvida na degradação óssea e pode ser expressa em altos níveis nos osteoclastos (130). A título de comparação, foram apresentados dois grupos controles. O primeiro, foi constituído de células RAW 264.7 pré-osteoclásticas, não estimuladas com rRANKL; enquanto o segundo grupo foi representado pela mesma linhagem celular, estimulada com rRANKL. Nesses dois grandes grupos foram analisados o papel dos peptídeos e controles clínicos em diferentes concentrações. Em ambos os grupos controles, na ausência e na presença de rRANKL, observou-se a manutenção da viabilidade celular.

A clavanina $A$ não apresentou nenhum grau de citotoxicidade às células RAW 264.7, fato demonstrado por não ter apresentado redução na viabilidade celular em nenhuma das concentrações testadas, com ou sem o estímulo de rRANKL. Este fato 
corrobora com um estudo anterior, onde a clavanina $A$ não demonstrou atividade citotóxica contra células de mamíferos até a concentração de 190 M (105). Em adição, foi sugerida uma possível proliferação celular na maior parte das concentrações testadas. Além disso, apresentaram baixos níveis de NO, de maneira semelhante ou inferior aos grupos controles, tanto na presença, quanto na ausência de rRANK. Por fim, apresentaram uma satisfatória redução na osteoclastogênese de maneira dose dependente, demonstrando melhor eficácia na concentração de $128 \mu \mathrm{g} \cdot \mathrm{mL}^{-1}$. Tais fatos entram em conformidade com outro estudo realizado anteriormente, que sugeriu a eficácia deste peptídeo na redução da osteoclastogênese em culturas de monócitos/macrófagos (7).

De forma bastante semelhante, foram apresentados os resultados da clavanina MO. Esse peptídeo demonstrou características de biocompatibilidade ao não apresentar citotoxicidade à cultura de células e ainda, possivelmente estimulando a proliferação celular em algumas concentrações, nas culturas estimuladas ou não com rRANKL. Em adição, a produção de NO se apresentou em baixos níveis sendo menores que os seus respectivos grupos controles com ou sem a adição de rRANKL, na maioria das concentrações, em 72 h. Este fato está em acordo com sua redução no número de osteoclastos diferenciados, que se apresentou de maneira semelhante em todas as concentrações testadas. Tais fatos reafirmam seu potencial imunomodulador (105), além da capacidade sugerida por um trabalho prévio de redução da osteoclastogênese in vitro na presença de clavanina $\mathrm{MO}(7)$.

A primeira menção a respeito da família das clavaninas foi reportado no fim da década de 90 (131), embora ainda possua poucos relatos na literatura a respeito de suas propriedades. No entanto, foi relatada atividade da clavanina A contra os microrganismos S.aureus, E. faecalis, E. faecium, L. monocytogenes, E. coli, S. typhimurium, $L$. pneumoniae e $P$. aeruginosa (131). Outro estudo relatou atividade das clavaninas A e MO contra S. aureus, E. coli e K. pneumoniae (105). Um estudo mais recente demonstrou que houve uma inibição de microrganismos presentes em infecções pulpares, com $19 \%$ e $27 \%$ do crescimento de C. albicans, a partir da clavanina A e clavanina $\mathrm{MO}$, respectivamente, a $128 \mu \mathrm{g} \cdot \mathrm{mL}^{-1}(<48 \mu \mathrm{M})$. Além disso, clavanina A foi capaz de inibir $61 \%$ do crescimento de $E$. faecalis, enquanto a clavanina MO inibiu 21\% a $1024 \mu \mathrm{g} \cdot \mathrm{mL}^{-1}$ (<385 $\left.\mu \mathrm{M}\right)$ (7). Em conclusão, acredita-se que o estímulo à produção da citocina pró-inflamatória TNF- $\alpha$ e ao mediador NO, a 
partir das clavaninas, pode favorecer a resposta antimicrobiana e, consequentemente, ativar o processo de reabsorção óssea (9). Estudo anterior ressaltou que as clavaninas não estimularam outras citocinas pró-inflamatórias avaliadas, que são sugeridas no envolvimento do processo de reabsorção óssea, o que pode associar-se à inibição da osteoclastogênese mediada por rRANKL, como relatado nesse estudo (7).

O peptídeo de defesa do hospedeiro LL-37 também apresentou resultados satisfatórios quanto a viabilidade celular. Dessa maneira, não demonstrou nenhum grau de citotoxicidade in vitro na presença ou na ausência de rRANKL. Quanto à produção de NO, apresentou estabilidade na maioria das concentrações testadas em relação ao controle. No entanto, foi demonstrada uma redução nos níveis de NO nas culturas de células RAW 264.7 na ausência do estímulo de rRANKL, após 72 h. De forma semelhante, a osteoclastogênese foi reduzida de maneira significativa, em maior grau nas concentrações de 8 e $128 \mu \mathrm{g} \cdot \mathrm{mL}^{-1}$. Além de todos os parâmetros favoráveis, a redução da osteoclastogênese nesse grupo, entra em acordo com as evidências apresentadas em diversos trabalhos descritos na literatura $(5,7,109)$.

Estudos revelaram que células da polpa dentária humana e células do ligamento periodontal podem dar suporte para diferenciação de osteoclastos por monócitos humanos. Os resultados sugerem que ambos os tipos celulares (da polpa e do ligamento), contribuem para o aumento da osteoclastogênese, frequentemente encontradas em lesões endo-perio, causadas por infecção de microrganismos orais. Foi observado que as catelicidinas suprimiram a osteoclastogênese induzida por RANKL em culturas de células mononucleares periféricas do sangue humano. As catelicidinas inibiram osteoclastogênese em co-culturas de osteoblastos de camundongos e células de medula óssea tratados com LPS e flagelina. Estes resultados sugerem que catelicidinas podem neutralizar ações do LPS e da flagelina. A LL-37 pode exibir atividade antimicrobiana contra $A$. actinomycetemcomitans e $P$. gingivalis. Tais estudos sugerem que as catelicidinas podem atuar como peptídeos protetores contra a reabsorção óssea induzida por infecção bacteriana em doenças periodontais. No entanto, ainda é necessário elucidar seus mecanismos de ação para que seja possível estabelecer novas estratégias de tratamento baseadas nessas biomoléculas (83).

Outros estudos afirmam que a deficiência de LL-37 pode estar relacionada com a periodontite agressiva. Dessa maneira, associa-se a hipótese de que a LL-37 
pode inibir a osteoclastogênese, devido a deficiência de LL-37 poder demonstrar reabsorção óssea severa, como observada na periodontite agressiva. Outros trabalhos, ainda reafirmam que a LL-37 exerce um efeito inibidor sobre a osteoclastogênese in vitro. No entanto, este efeito ainda não foi completamente caracterizado, embora estudos venham sugerindo que as doses não-tóxicas de LL37 podem bloquear a fusão celular de monócitos. Além disso, estudos demonstraram que a LL-37 diminuiu significativamente a atividade da calcineurina, resultando no bloqueio da translocação nuclear (NFAT2) e a baixa-regulação da expressão de RNAm de vários genes. Dessa maneira, tem sido proposto que o eixo de calcineurina / NFAT2 pode ser uma via de sinalização crítica para a inibição da osteoclastogênese in vitro por LL-37 (109). Por outro lado, resultados in vitro devem ser interpretados com cautela, uma vez que são necessários outros estudos in vivo, antes de extrapolar para o uso clínico dessa biomolécula.

O controle clínico $\mathrm{Ca}(\mathrm{OH})_{2}$, sugeriu uma possível proliferação celular na maior parte das concentrações e tempos experimentais, em culturas estimuladas ou não com rRANKL. Em adição, apresentou resultados semelhantes a LL-37 no que diz respeito à produção de óxido nítrico. Com relação à osteoclastogênese, este controle clínico apresentou redução no número de osteoclastos na presença de todas as concentrações testadas. No entanto, tal redução foi demonstrada com maior evidência na presença de 8 ug. $\mathrm{mL}^{-1}$ dessa medicação. Tais fatos entram em acordo com resultados prévios que sugeriram a inibição da osteoclastogênese na presença dessa medicação intracanal (7). Outros estudos sugerem que $\mathrm{opH}$ alcalino pode neutralizar o ácido lático secretado por osteoclastos e pode ajudar a prevenir a destruição de tecido mineralizado (132). Lima (7) ressaltou que seus estudos não analisaram o processo de osteoclastogênese em sua complexidade, dessa maneira, devido a não haver o envolvimento de outras células produtoras de outros mediadores inflamatórios que podem atuar em diferentes fases deste processo, culminando na inibição e/ou redução do mesmo (7). De forma semelhante, nossos estudos basearam-se apenas em culturas in vitro, portanto, a hipótese da performance de redução na osteoclastogênese pelo $\mathrm{Ca}(\mathrm{OH})_{2}$, necessita de confirmação por meio de estudos in vivo.

Por fim, na medicação doxiciclina foi observada a toxicidade desse produto em contato com a cultura celular na concentração de $128 \mu \mathrm{g} \cdot \mathrm{mL}^{-1}$, evidenciada em $72 \mathrm{~h}$ de cultura, na presença e na ausência de rRANKL. No entanto, menores 
concentrações (2 e $8 \mu \mathrm{g} \cdot \mathrm{mL}^{-1}$ ) sugeriram uma possível proliferação celular, especialmente na presença de rRANKL, após 7 d de cultura. Esse fato está em acordo com propostas de uso de doses subantimicrobianas de doxiciclina, que podem favorecer o reparo tecidual agindo nas MMPs (2). Em adição, notou-se uma elevação nos níveis de NO, especialmente na concentração de $2 \mu \mathrm{g} \cdot \mathrm{mL}^{-1}$. Por fim, a diferenciação de osteoclastos foi reduzida de maneira dose dependente, apresentando a menor redução na concentração de $128 \mu \mathrm{g} \cdot \mathrm{mL}^{-1}$. Tais fatos sugerem que embora o NO esteja fortemente associado à diferenciação de osteoclastos, este não seja o único fator envolvido na osteoclastogênese e provavelmente a via de diminuição da osteoclastogênese pela doxiciclina (133), se deve por outras explicações. Essa informação se evidencia na concentração de $2 \mu \mathrm{g} \cdot \mathrm{mL}^{-1}$, que apesar de demonstrar maiores níveis de NO, apresentou redução menos expressiva na osteoclastogênese em comparação com as outras concentrações testadas dessa medicação.

Alguns autores apontam que as tetraciclinas, incluindo a doxiciclina, têm sido utilizadas para tratar doenças que envolvem a reabsorção óssea, por poderem apresentar atividades capazes de suprimir a osteoclastogênese induzida por RANKL. Dessa forma, tais autores apontam que o mecanismo subjacente ao efeito inibitório sobre a osteoclastogênese mediada por doxiciclina, pode depender da inibição da atividade da enzima MMP-9, independente da cascata de sinalização de MAPK-NFATc1(134). Por outro lado, outros resultados sugerem que a sinalização de MAPK pode estar envolvida na diferenciação de osteoclastos. A sinalização de MAPK e c-Fos pode exercer um papel essencial na diferenciação de osteoclastos. Diante disso, acredita-se que a doxiciclina pode inibir a osteoclastogênese mediada por RANKL pela supressão de MAPKs e c-Fos em células da medula óssea (135).

Em suma, os resultados sugerem que os PDHs testados neste estudo, além dos controles clínicos foram capazes de reduzir a osteoclastogênese em maior ou menor grau. No entanto, destacam-se os resultados observados no peptídeo LL-37 e no controle clínico $\mathrm{Ca}(\mathrm{OH})_{2}$. Estes resultados foram melhores observados na concentração de $8 \mu \mathrm{g} \cdot \mathrm{mL}^{-1}$. Desta maneira, pode-se levar em consideração a ideia de um possível produto com aplicações endodônticas e periodontais, no intuito de reduzir os processos de osteoclastogênese, embora maiores elucidações a respeito de seus mecanismos ainda se fazem necessários. Por outro lado, o $\mathrm{Ca}(\mathrm{OH})_{2}$ apresenta um baixo custo de produção quando comparado à LL-37. Isso ocorre 
devido à LL-37 apresentar uma sequência relativamente longa de aminoácidos, fato que pode elevar os custos da sua síntese. No entanto, diante dos prováveis benefícios imunomodulatórios e sua biocompatibilidade por ser um peptídeo presente na cavidade bucal, a LL-37 representa uma boa aplicabilidade na odontologia. Devido ao seu alto custo de síntese, provavelmente esse PDH teria indicação para casos restritos, apresentando-se como uma alternativa de tratamento. Já em comparação com a doxiciclina, a LL-37 apresentou maiores benefícios na redução da osteoclastogênese em baixas concentrações, representando um potencial ainda maior no contexto da perda óssea, comparada à essa medicação utilizada clinicamente.

Apesar dos benefícios evidenciados neste trabalho, outros parâmetros devem ser avaliados com a finalidade de desvendar os mecanismos inerentes à estes potenciais produtos com indicação em processos de reabsorção óssea, como os presentes em lesões perirradiculares e na periodontite. Outros pontos importantes para futuros trabalhos, estariam voltados para expressão em larga escala deste peptídeo (baixando seu custo) e análise de sua integridade mediante as diversas condições orais, como alterações de temperatura, pH e presença de enzimas líticas. 


\section{CONCLUSÃO}

Diante dos resultados obtidos por meio das análises dos peptídeos de defesa do hospedeiro clavanina A, clavanina MO e LL-37, e dos controles clínicos $\mathrm{Ca}(\mathrm{OH})_{2}$ e doxiciclina in vitro foi possível concluir que:

- As células RAW 264.7 foram capazes de se diferenciar em osteoclastos multinucleados na presença de $100 \mathrm{ng} \cdot \mathrm{mL}^{-1}$ de rRANKL;

- $\quad$ Os PDHs clavanina A, clavanina MO e LL-37 e os controles clínicos $\mathrm{Ca}(\mathrm{OH})_{2}$ e doxiciclina, não apresentaram citotoxicidade às células RAW 264.7 na presença ou ausência de rRANKL;

- O rRANKL pode induzir o aumento dos níveis de NO nas células RAW 264.7

- Os PDHs e os controles clínicos foram capazes de suprimir o processo de osteoclastogênese in vitro;

- $\quad$ O peptídeo LL-37 e a medicação $\mathrm{Ca}(\mathrm{OH})_{2}$ apresentaram os melhores resultados na redução da osteoclastogênese na concentração $8 \mu \mathrm{g} \cdot \mathrm{mL}^{-1}$;

- As clavaninas A e $\mathrm{MO}$ e a doxiciclina apresentaram redução semelhante na osteoclastogênese in vitro, na concentração $8 \mu \mathrm{g} \cdot \mathrm{mL}^{-1}$;

- A doxiciclina demonstrou citotoxicidade na concentração $128 \mu \mathrm{g} \cdot \mathrm{mL}^{-1}$, após $72 \mathrm{~h}$ de cultivo celular na presença e na ausência de rRANKL;

- A doxiciclina sugeriu grande proliferação celular na concentração de 2 $\mu \mathrm{g} \cdot \mathrm{mL}^{-1}$, principalmente na ausência de rRANKL.

Devido aos PDHs apresentarem-se como potenciais supressores da osteoclastogênese in vitro, podem representar promissores no desenvolvimento de fármacos para o tratamento de patologias que envolvem reabsorção óssea perirradicular e periodontal. No entanto, a partir do comportamento dos PDHs e controles clínicos apresentados nesse trabalho in vitro, faz-se necessário o entendimento em níveis moleculares, dos mecanismos de inibição envolvidos na osteoclastogênese mediada por rRANKL, na presença dessas moléculas. Dessa forma, deve-se interpretar com cautela tais resultados, e novas pesquisas acerca desse tema devem ser realizadas, fato que será temática de estudos futuros do grupo. 


\section{REFERÊNCIAS BIBLIOGRÁFICAS}

1. Ihan Hren N, Ihan A. T lymphocyte activation and cytokine expression in periapical granulomas and radicular cysts. Archives of oral biology. 2009;54(2):15661.

2. Castro ML, Franco GC, Branco-de-Almeida LS, Anbinder AL, Cogo-Muller K, Cortelli SC, et al. Downregulation of Proteinase-Activated Receptor-2, Interleukin-17, and Other Proinflammatory Genes by Subantimicrobial Doxycycline Dose in a Rat Periodontitis Model. Journal of periodontology. 2016;87(2):203-10.

3. Siqueira JF, Jr., Rocas IN. Clinical implications and microbiology of bacterial persistence after treatment procedures. Journal of endodontics. 2008;34(11):1291301 e3.

4. Santos RS, Macedo RF, Souza EA, Soares RS, Feitosa DS, Sarmento CF. The use of systemic antibiotics in the treatment of refractory periodontitis: A systematic review. Journal of the American Dental Association. 2016.

5. Gorr SU, Abdolhosseini M. Antimicrobial peptides and periodontal disease. Journal of clinical periodontology. 2011;38 Suppl 11:126-41.

6. Wimley WC. Describing the mechanism of antimicrobial peptide action with the interfacial activity model. ACS chemical biology. 2010;5(10):905-17.

7. Lima SMdF. Peptídeos antimicrobianos potenciais para terapia endodôntica: análise antimicrobiana, imunológica e osteoclastogênica in vitro [Dissertação de mestrado]: Brasília, DF: Universidade Católica de Brasília (UCB). ; 2014.

8. Alford Al, Kozloff KM, Hankenson KD. Extracellular matrix networks in bone remodeling. The international journal of biochemistry \& cell biology. 2015;65:20-31.

9. Fukada SY, Silva TA, Garlet GP, Rosa AL, da Silva JS, Cunha FQ. Factors involved in the $T$ helper type 1 and type 2 cell commitment and osteoclast regulation in inflammatory apical diseases. Oral microbiology and immunology. 2009;24(1):2531.

10. Kim HJ, Kang WY, Seong SJ, Kim SY, Lim MS, Yoon YR. Follistatin-like 1 promotes osteoclast formation via RANKL-mediated NF-kappaB activation and MCSF-induced precursor proliferation. Cellular signalling. 2016;28(9):1137-44. 
11. Handzlik-Orlik G, Holecki M, Wilczynski K, Dulawa J. Osteoporosis in liver disease: pathogenesis and management. Therapeutic advances in endocrinology and metabolism. 2016;7(3):128-35.

12. Wang YD, Wang L, Li DJ, Wang WJ. Dehydroepiandrosterone inhibited the bone resorption through the upregulation of OPG/RANKL. Cellular \& molecular immunology. 2006;3(1):41-5.

13. Sigl V, Owusu-Boaitey K, Joshi PA, Kavirayani A, Wirnsberger G, Novatchkova $M$, et al. RANKL/RANK control Brca1 mutation-driven mammary tumors. Cell research. 2016.

14. Alliston T. Biological regulation of bone quality. Current osteoporosis reports. 2014;12(3):366-75.

15. Yang $Y$, Huang $Y$, Zhang $L$, Zhang $C$. Transcriptional regulation of bone sialoprotein gene expression by Osx. Biochemical and biophysical research communications. 2016.

16. Islam S, Hassan F, Tumurkhuu G, Dagvadorj J, Koide N, Naiki Y, et al. Receptor activator of nuclear factor-kappa $B$ ligand induces osteoclast formation in RAW 264.7 macrophage cells via augmented production of macrophage-colonystimulating factor. Microbiology and immunology. 2008;52(12):585-90.

17. Taubman MA, Kawai T. Involvement of T-lymphocytes in periodontal disease and in direct and indirect induction of bone resorption. Critical reviews in oral biology and medicine : an official publication of the American Association of Oral Biologists. 2001;12(2):125-35.

18. Ohishi M, Matsumura Y, Aki D, Mashima R, Taniguchi K, Kobayashi T, et al. Suppressors of cytokine signaling-1 and -3 regulate osteoclastogenesis in the presence of inflammatory cytokines. Journal of immunology. 2005;174(5):3024-31.

19. Palmqvist $P$, Lundberg $P$, Persson E, Johansson A, Lundgren I, Lie A, et al. Inhibition of hormone and cytokine-stimulated osteoclastogenesis and bone resorption by interleukin-4 and interleukin-13 is associated with increased osteoprotegerin and decreased RANKL and RANK in a STAT6-dependent pathway. The Journal of biological chemistry. 2006;281(5):2414-29.

20. Czupalla C, Mansukoski H, Riedl T, Thiel D, Krause E, Hoflack B. Proteomic analysis of lysosomal acid hydrolases secreted by osteoclasts: implications for lytic enzyme transport and bone metabolism. Molecular \& cellular proteomics : MCP. 2006;5(1):134-43. 
21. Lima SM, de Padua GM, Sousa MG, Freire Mde S, Franco OL, Rezende TM. Antimicrobial peptide-based treatment for endodontic infections--biotechnological innovation in endodontics. Biotechnology advances. 2015;33(1):203-13.

22. Sato K, Suematsu A, Okamoto K, Yamaguchi A, Morishita $Y$, Kadono $Y$, et al. Th17 functions as an osteoclastogenic helper $T$ cell subset that links $T$ cell activation and bone destruction. The Journal of experimental medicine. 2006;203(12):2673-82.

23. Teixeira MK, Lira-Junior R, Telles DM, Lourenco EJ, Figueredo CM. Th17related cytokines in mucositis: is there any difference between peri-implantitis and periodontitis patients? Clinical oral implants research. 2016.

24. Colic M, Gazivoda D, Vucevic D, Vasilijic S, Rudolf R, Lukic A. Proinflammatory and immunoregulatory mechanisms in periapical lesions. Molecular immunology. 2009;47(1):101-13.

25. Armada L, Marotta Pdos S, Pires FR, Siqueira JF, Jr. Expression and Distribution of Receptor Activator of Nuclear Factor Kappa B, Receptor Activator of Nuclear Factor Kappa B Ligand, and Osteoprotegerin in Periradicular Cysts. Journal of endodontics. 2015;41(8):1281-7.

26. Kayal RA. The role of osteoimmunology in periodontal disease. BioMed research international. 2013;2013:639368.

27. Mahanonda R, Champaiboon C, Subbalekha K, Sa-Ard-lam N, Rattanathammatada W, Thawanaphong S, et al. Human Memory B Cells in Healthy Gingiva, Gingivitis, and Periodontitis. Journal of immunology. 2016.

28. Tompkins KA. The osteoimmunology of alveolar bone loss. Connective tissue research. 2016;57(2):69-90.

29. Barbato L, Francioni E, Bianchi M, Mascitelli E, Marco LB, Tonelli DP. Periodontitis and bone metabolism. Clinical cases in mineral and bone metabolism : the official journal of the Italian Society of Osteoporosis, Mineral Metabolism, and Skeletal Diseases. 2015;12(2):174-7.

30. Lee JY, Lee YM, Shin SY, Seol YJ, Ku Y, Rhyu IC, et al. Effect of subantimicrobial dose doxycycline as an effective adjunct to scaling and root planing. Journal of periodontology. 2004;75(11):1500-8.

31. Horton JE, Raisz LG, Simmons HA, Oppenheim JJ, Mergenhagen SE. Bone resorbing activity in supernatant fluid from cultured human peripheral blood leukocytes. Science. 1972;177(4051):793-5. 
32. Mundy GR, Raisz LG, Cooper RA, Schechter GP, Salmon SE. Evidence for the secretion of an osteoclast stimulating factor in myeloma. The New England journal of medicine. 1974;291(20):1041-6.

33. Dewhirst FE, Stashenko PP, Mole JE, Tsurumachi T. Purification and partial sequence of human osteoclast-activating factor: identity with interleukin 1 beta. Journal of immunology. 1985;135(4):2562-8.

34. Takayanagi $\mathrm{H}$. Osteoimmunology: shared mechanisms and crosstalk between the immune and bone systems. Nature reviews Immunology. 2007;7(4):292-304.

35. Chiu YG, Ritchlin CT. DC-STAMP: A Key Regulator in Osteoclast Differentiation. Journal of cellular physiology. 2016.

36. Kular J, Tickner J, Chim SM, Xu J. An overview of the regulation of bone remodelling at the cellular level. Clinical biochemistry. 2012;45(12):863-73.

37. Weitzmann MN, Ofotokun I. Physiological and pathophysiological bone turnover - role of the immune system. Nature reviews Endocrinology. 2016.

38. D'Amelio P, Sassi F. Osteoimmunology: from mice to humans. BoneKEy reports. 2016;5:802.

39. Guerrini MM, Takayanagi $H$. The immune system, bone and RANKL. Archives of biochemistry and biophysics. 2014;561:118-23.

40. Miron RJ, Bosshardt DD. OsteoMacs: Key players around bone biomaterials. Biomaterials. 2016;82:1-19.

41. Li Y, Toraldo G, Li A, Yang X, Zhang H, Qian WP, et al. B cells and T cells are critical for the preservation of bone homeostasis and attainment of peak bone mass in vivo. Blood. 2007;109(9):3839-48.

42. Sasaki H, Hirai K, Martins CM, Furusho H, Battaglino R, Hashimoto K. Interrelationship Between Periapical Lesion and Systemic Metabolic Disorders. Current pharmaceutical design. 2016;22(15):2204-15.

43. Jancso N, Jancso-Gabor A, Szolcsanyi J. Direct evidence for neurogenic inflammation and its prevention by denervation and by pretreatment with capsaicin. British journal of pharmacology and chemotherapy. 1967;31(1):138-51.

44. Lima SM, Sousa MG, Freire Mde S, de Almeida JA, Cantuaria AP, Silva TA, et al. Immune Response Profile against Persistent Endodontic Pathogens Candida albicans and Enterococcus faecalis In Vitro. Journal of endodontics. 2015;41(7):1061-5. 
45. Hall BE, Zhang L, Sun ZJ, Utreras E, Prochazkova M, Cho A, et al. Conditional TNF-alpha Overexpression in the Tooth and Alveolar Bone Results in Painful Pulpitis and Osteitis. Journal of dental research. 2016;95(2):188-95.

46. Stashenko P, Goncalves RB, Lipkin B, Ficarelli A, Sasaki H, Campos-Neto A. Th1 immune response promotes severe bone resorption caused by Porphyromonas gingivalis. The American journal of pathology. 2007;170(1):203-13.

47. Sasaki H, Hou L, Belani A, Wang CY, Uchiyama T, Muller R, et al. IL-10, but not IL-4, suppresses infection-stimulated bone resorption in vivo. Journal of immunology. 2000;165(7):3626-30.

48. Leite AC, Carneiro VM, Guimaraes Mdo C. Effects of periodontal therapy on C-reactive protein and HDL in serum of subjects with periodontitis. Revista brasileira de cirurgia cardiovascular : orgao oficial da Sociedade Brasileira de Cirurgia Cardiovascular. 2014;29(1):69-77.

49. Garlet GP. Destructive and protective roles of cytokines in periodontitis: a reappraisal from host defense and tissue destruction viewpoints. Journal of dental research. 2010;89(12):1349-63.

50. Li W, Zhu Y, Singh P, Ajmera DH, Song J, Ji P. Association of Common Variants in MMPs with Periodontitis Risk. Disease markers. 2016;2016:1545974.

51. Mohamed HG, Idris SB, Mustafa M, Ahmed MF, Astrom AN, Mustafa K, et al. Influence of Type 2 Diabetes on Prevalence of Key Periodontal Pathogens, Salivary Matrix Metalloproteinases, and Bone Remodeling Markers in Sudanese Adults with and without Chronic Periodontitis. International journal of dentistry. 2016;2016:6296854.

52. Sima C, Glogauer M. Macrophage subsets and osteoimmunology: tuning of the immunological recognition and effector systems that maintain alveolar bone. Periodontology 2000. 2013;63(1):80-101.

53. Mungrue IN, Bredt DS, Stewart DJ, Husain M. From molecules to mammals: what's NOS got to do with it? Acta physiologica Scandinavica. 2003;179(2):123-35.

54. Sosroseno W, Bird PS, Seymour GJ. Nitric oxide production by a murine macrophage cell line (RAW264.7 cells) stimulated with Aggregatibacter actinomycetemcomitans surface-associated material. Anaerobe. 2011;17(5):246-51.

55. Silva MJ, Sousa LM, Lara VP, Cardoso FP, Junior GM, Totola AH, et al. The role of iNOS and PHOX in periapical bone resorption. Journal of dental research. 2011;90(4):495-500. 
56. Zhang JH, Shangguan ZS, Chen C, Zhang HJ, Lin Y. Anti-inflammatory effects of guggulsterone on murine macrophage by inhibiting LPS-induced inflammatory cytokines in NF-kappaB signaling pathway. Drug design, development and therapy. 2016;10:1829-35.

57. van't Hof RJ, Armour KJ, Smith LM, Armour KE, Wei XQ, Liew FY, et al. Requirement of the inducible nitric oxide synthase pathway for IL-1-induced osteoclastic bone resorption. Proceedings of the National Academy of Sciences of the United States of America. 2000;97(14):7993-8.

58. Damoulis PD, Hauschka PV. Nitric oxide acts in conjunction with proinflammatory cytokines to promote cell death in osteoblasts. Journal of bone and mineral research : the official journal of the American Society for Bone and Mineral Research. 1997;12(3):412-22.

59. De Couto Pita A, Passafaro D, Ganzinelli S, Borda E, Sterin-Borda L. Differential cholinoceptor modulation of nitric oxide isoforms in experimentallyinduced inflammation of dental pulp tissue. International endodontic journal. 2009;42(6):525-33.

60. Takimoto K, Kawashima N, Suzuki N, Koizumi Y, Yamamoto M, Nakashima M, et al. Down-regulation of inflammatory mediator synthesis and infiltration of inflammatory cells by MMP-3 in experimentally induced rat pulpitis. Journal of endodontics. 2014;40(9):1404-9.

61. Backlund CJ, Sergesketter AR, Offenbacher S, Schoenfisch MH. Antibacterial efficacy of exogenous nitric oxide on periodontal pathogens. Journal of dental research. 2014;93(11):1089-94.

62. Haapasalo M, Shen Y, Qian W, Gao Y. Irrigation in endodontics. Dental clinics of North America. 2010;54(2):291-312.

63. Haapasalo M, Qian W, Portenier I, Waltimo T. Effects of dentin on the antimicrobial properties of endodontic medicaments. Journal of endodontics. 2007;33(8):917-25.

64. Haapasalo M, Shen Y, Wang Z, Gao Y. Irrigation in endodontics. British dental journal. 2014;216(6):299-303.

65. Matsubara VH, Bandara HM, Ishikawa KH, Mayer MP, Samaranayake LP. The role of probiotic bacteria in managing periodontal disease: a systematic review. Expert review of anti-infective therapy. 2016;14(7):643-55. 
66. Socransky SS, Haffajee AD. Dental biofilms: difficult therapeutic targets. Periodontology 2000. 2002;28:12-55.

67. Rocas IN, Provenzano JC, Neves MA, Siqueira JF, Jr. Disinfecting Effects of Rotary Instrumentation with Either $2.5 \%$ Sodium Hypochlorite or $2 \%$ Chlorhexidine as the Main Irrigant: A Randomized Clinical Study. Journal of endodontics. 2016;42(6):943-7.

68. Rocas IN, Siqueira JF, Jr. In vivo antimicrobial effects of endodontic treatment procedures as assessed by molecular microbiologic techniques. Journal of endodontics. $2011 ; 37(3): 304-10$.

69. Craig RG, Zuroff M, Rosenberg PA. The effect of endodontic materials on periodontal ligament cell proliferation, alkaline phosphatase activity, and extracellular matrix protein synthesis in vitro. Journal of endodontics. 1997;23(8):494-8.

70. Ricucci D, Siqueira JF, Jr. Fate of the tissue in lateral canals and apical ramifications in response to pathologic conditions and treatment procedures. Journal of endodontics. 2010;36(1):1-15.

71. Estrela C, Sydney GB, Bammann LL, Felippe Junior O. Mechanism of action of calcium and hydroxyl ions of calcium hydroxide on tissue and bacteria. Brazilian dental journal. 1995;6(2):85-90.

72. Siqueira JF, Jr., Lopes HP. Mechanisms of antimicrobial activity of calcium hydroxide: a critical review. Int Endod J. 1999;32(5):361-9.

73. Athanassiadis B, Abbott PV, Walsh LJ. The use of calcium hydroxide, antibiotics and biocides as antimicrobial medicaments in endodontics. Australian dental journal. 2007;52(1 Suppl):S64-82.

74. Russell AD. Biocide use and antibiotic resistance: the relevance of laboratory findings to clinical and environmental situations. The Lancet Infectious diseases. 2003;3(12):794-803.

75. Ricucci D, Siqueira JF, Jr. Recurrent apical periodontitis and late endodontic treatment failure related to coronal leakage: a case report. Journal of endodontics. $2011 ; 37(8): 1171-5$.

76. Franco EJ, Pogue RE, Sakamoto LH, Cavalcante LL, Carvalho DR, de Andrade RV. Increased expression of genes after periodontal treatment with photodynamic therapy. Photodiagnosis and photodynamic therapy. 2014;11(1):41-7. 
77. Deas DE, Moritz AJ, Sagun RS, Jr., Gruwell SF, Powell CA. Scaling and root planing vs. conservative surgery in the treatment of chronic periodontitis. Periodontology 2000. 2016;71(1):128-39.

78. Decker EM, Bartha V, Kopunic A, von Ohle C. Antimicrobial efficiency of mouthrinses versus and in combination with different photodynamic therapies on periodontal pathogens in an experimental study. Journal of periodontal research. 2016.

79. Akram Z, Al-Shareef SA, Daood U, Asiri FY, Shah AH, AIQahtani MA, et al. Bactericidal Efficacy of Photodynamic Therapy Against Periodontal Pathogens in Periodontal Disease: A Systematic Review. Photomedicine and laser surgery. 2016;34(4):137-49.

80. Smiley CJ, Tracy SL, Abt E, Michalowicz BS, John MT, Gunsolley J, et al. Evidence-based clinical practice guideline on the nonsurgical treatment of chronic periodontitis by means of scaling and root planing with or without adjuncts. Journal of the American Dental Association. 2015;146(7):525-35.

81. Carris NW, Pardo J, Montero J, Shaeer KM. Minocycline as A Substitute for Doxycycline in Targeted Scenarios: A Systematic Review. Open forum infectious diseases. 2015;2(4):ofv178.

82. Lopez-Abarrategui C, Alba A, Silva ON, Reyes-Acosta O, Vasconcelos IM, Oliveira JT, et al. Functional characterization of a synthetic hydrophilic antifungal peptide derived from the marine snail Cenchritis muricatus. Biochimie. 2012;94(4):968-74.

83. Nakamichi Y, Horibe K, Takahashi N, Udagawa N. Roles of cathelicidins in inflammation and bone loss. Odontology / the Society of the Nippon Dental University. 2014;102(2):137-46.

84. Lucchese A, Guida A, Petruzzi M, Capone G, Laino L, Serpico R. Peptides in oral diseases. Current pharmaceutical design. 2012;18(6):782-8.

85. da Silva BR, de Freitas VA, Nascimento-Neto LG, Carneiro VA, Arruda FV, de Aguiar AS, et al. Antimicrobial peptide control of pathogenic microorganisms of the oral cavity: a review of the literature. Peptides. 2012;36(2):315-21.

86. Brogden KA. Antimicrobial peptides: pore formers or metabolic inhibitors in bacteria? Nature reviews Microbiology. 2005;3(3):238-50. 
87. Gkeka P, Sarkisov L. Interactions of phospholipid bilayers with several classes of amphiphilic alpha-helical peptides: insights from coarse-grained molecular dynamics simulations. The journal of physical chemistry B. 2010;114(2):826-39.

88. Lee SH, Jun HK, Lee HR, Chung CP, Choi BK. Antibacterial and lipopolysaccharide (LPS)-neutralising activity of human cationic antimicrobial peptides against periodontopathogens. International journal of antimicrobial agents. 2010;35(2):138-45.

89. Bozelli JC, Jr., Sasahara ET, Pinto MR, Nakaie CR, Schreier S. Effect of head group and curvature on binding of the antimicrobial peptide tritrpticin to lipid membranes. Chemistry and physics of lipids. 2012;165(4):365-73.

90. Tamba Y, Yamazaki M. Single giant unilamellar vesicle method reveals effect of antimicrobial peptide magainin 2 on membrane permeability. Biochemistry. 2005;44(48):15823-33.

91. Hristova K, Selsted ME, White SH. Critical role of lipid composition in membrane permeabilization by rabbit neutrophil defensins. The Journal of biological chemistry. 1997;272(39):24224-33.

92. Hancock RE, Scott MG. The role of antimicrobial peptides in animal defenses. Proceedings of the National Academy of Sciences of the United States of America. 2000;97(16):8856-61.

93. Pepperney A, Chikindas ML. Antibacterial Peptides: Opportunities for the Prevention and Treatment of Dental Caries. Probiotics and antimicrobial proteins. 2011;3(2):68.

94. Cross KJ, Huq NL, Reynolds EC. Casein phosphopeptides in oral health-chemistry and clinical applications. Current pharmaceutical design. 2007;13(8):793800 .

95. Turner SR, Love RM, Lyons KM. An in-vitro investigation of the antibacterial effect of nisin in root canals and canal wall radicular dentine. International endodontic journal. 2004;37(10):664-71.

96. Lee JK, Park YJ, Kum KY, Han SH, Chang SW, Kaufman B, et al. Antimicrobial efficacy of a human beta-defensin-3 peptide using an Enterococcus faecalis dentine infection model. International endodontic journal. 2013;46(5):406-12. 97. Kluver E, Schulz-Maronde S, Scheid S, Meyer B, Forssmann WG, Adermann K. Structure-activity relation of human beta-defensin 3: influence of disulfide bonds 
and cysteine substitution on antimicrobial activity and cytotoxicity. Biochemistry. 2005;44(28):9804-16.

98. van Kan EJ, Ganchev DN, Snel MM, Chupin V, van der Bent A, de Kruijff B. The peptide antibiotic clavanin A interacts strongly and specifically with lipid bilayers. Biochemistry. 2003;42(38):11366-72.

99. Silva ON, Fensterseifer IC, Rodrigues EA, Holanda HH, Novaes NR, Cunha JP, et al. Clavanin A improves outcome of complications from different bacterial infections. Antimicrobial agents and chemotherapy. 2015;59(3):1620-6.

100. van Kan EJ, van der Bent A, Demel RA, de Kruijff B. Membrane activity of the peptide antibiotic clavanin and the importance of its glycine residues. Biochemistry. 2001;40(21):6398-405.

101. Lee IH, Zhao C, Nguyen T, Menzel L, Waring AJ, Sherman MA, et al. Clavaspirin, an antibacterial and haemolytic peptide from Styela clava. The journal of peptide research : official journal of the American Peptide Society. 2001;58(6):44556.

102. van Kan EJ, Demel RA, Breukink E, van der Bent A, de Kruijff B. Clavanin permeabilizes target membranes via two distinctly different $\mathrm{pH}$-dependent mechanisms. Biochemistry. 2002;41(24):7529-39.

103. Silva ON, Migliolo, L., Dias, S. C., Rezende, T. M. B., Franco, O. L., inventorPatent: Antimicrobial, insecticide and antitumor synthetic molecule, composition, use and microorganism inhibition method. INPI. Brazil Patent Number 0000221109717908 . Brazil2011.

104. Mulder KC, de Lima LA, Aguiar PS, Carneiro FC, Franco OL, Dias SC, et al. Production of a modified peptide clavanin in Pichia pastoris: cloning, expression, purification and in vitro activities. AMB Express. 2015;5(1):129.

105. Silva ON. Avaliação do potencial terapêutico e estudo da atividade imunomodulatória e antimicrobiana in vitro e in vivo de diferentes formas de clavaninas. (Mestrado). . Programa de Pós Graduação em Ciências Biológicas (Imunologia e Doenças Infecto Parasitárias / Genética e Biotecnologia), Universidade Federal de Juiz de Fora, Juiz de Fora, MG. 2011.

106. Makeudom A, Kulpawaropas S, Montreekachon P, Khongkhunthian S, Sastraruji T, Pothacharoen P, et al. Positive correlations between hCAP18/LL-37 and chondroitin sulphate levels in chronic periodontitis. Journal of clinical periodontology. 2014;41(3):252-61. 
107. Bowdish DM, Davidson DJ, Lau YE, Lee K, Scott MG, Hancock RE. Impact of LL-37 on anti-infective immunity. Journal of leukocyte biology. 2005;77(4):451-9.

108. Durr UH, Sudheendra US, Ramamoorthy A. LL-37, the only human member of the cathelicidin family of antimicrobial peptides. Biochimica et biophysica acta. 2006;1758(9):1408-25.

109. Supanchart C, Thawanaphong S, Makeudom A, Bolscher JG, Nazmi K, Kornak U, et al. The antimicrobial peptide, LL-37, inhibits in vitro osteoclastogenesis. Journal of dental research. 2012;91(11):1071-7.

110. Carretero M, Escamez MJ, Garcia M, Duarte B, Holguin A, Retamosa L, et al. In vitro and in vivo wound healing-promoting activities of human cathelicidin LL-37. The Journal of investigative dermatology. 2008;128(1):223-36.

111. Huynh-Do U, Vindis C, Liu H, Cerretti DP, McGrew JT, Enriquez M, et al. Ephrin-B1 transduces signals to activate integrin-mediated migration, attachment and angiogenesis. Journal of cell science. 2002;115(Pt 15):3073-81.

112. Kajiya M, Shiba H, Komatsuzawa H, Ouhara K, Fujita T, Takeda K, et al. The antimicrobial peptide LL37 induces the migration of human pulp cells: a possible adjunct for regenerative endodontics. Journal of endodontics. 2010;36(6):1009-13.

113. Maggiora LL, Smith CW, Zhang ZY. A general method for the preparation of internally quenched fluorogenic protease substrates using solid-phase peptide synthesis. Journal of medicinal chemistry. 1992;35(21):3727-30.

114. Murphy J, and M. Kies. Note on the spectrophotometric determination of proteins in dilute solutions. Biochim Biophys Acta 1960;3:382-4.

115. van de Loosdrecht AA, Nennie E, Ossenkoppele GJ, Beelen $R H$, Langenhuijsen MM. Cell mediated cytotoxicity against $U 937$ cells by human monocytes and macrophages in a modified colorimetric MTT assay. A methodological study. Journal of immunological methods. 1991;141(1):15-22.

116. Mosmann T. Rapid colorimetric assay for cellular growth and survival: application to proliferation and cytotoxicity assays. Journal of immunological methods. 1983;65(1-2):55-63.

117. Green LC, Wagner DA, Glogowski J, Skipper PL, Wishnok JS, Tannenbaum SR. Analysis of nitrate, nitrite, and $[15 \mathrm{~N}]$ nitrate in biological fluids. Analytical biochemistry. 1982;126(1):131-8.

118. Goldberg AF, Barka T. Acid phosphatase activity in human blood cells. Nature. 1962;195:297. 
119. Saha S, Nair R, Asrani H. Comparative Evaluation of Propolis, Metronidazole with Chlorhexidine, Calcium Hydroxide and Curcuma Longa Extract as Intracanal Medicament Against E.faecalis- An Invitro Study. Journal of clinical and diagnostic research : JCDR. 2015;9(11):ZC19-21.

120. Chan $\mathrm{CL}$, You $\mathrm{HJ}$, Lian $\mathrm{HJ}$, Huang $\mathrm{CH}$. Patients receiving comprehensive periodontal treatment have better clinical outcomes than patients receiving conventional periodontal treatment. Journal of the Formosan Medical Association = Taiwan yi zhi. 2016;115(3):152-62.

121. Silva ON, Mulder KC, Barbosa AE, Otero-Gonzalez AJ, Lopez-Abarrategui C, Rezende TM, et al. Exploring the pharmacological potential of promiscuous hostdefense peptides: from natural screenings to biotechnological applications. Frontiers in microbiology. 2011;2:232.

122. Gutner M, Chaushu S, Balter D, Bachrach G. Saliva enables the antimicrobial activity of LL-37 in the presence of proteases of Porphyromonas gingivalis. Infection and immunity. 2009;77(12):5558-63.

123. Raschke WC, Baird S, Ralph P, Nakoinz I. Functional macrophage cell lines transformed by Abelson leukemia virus. Cell. 1978;15(1):261-7.

124. Horibe K, Nakamichi Y, Uehara S, Nakamura M, Koide M, Kobayashi Y, et al. Roles of cathelicidin-related antimicrobial peptide in murine osteoclastogenesis. Immunology. 2013;140(3):344-51.

125. Takahashi N, Udagawa N, Suda T. A new member of tumor necrosis factor ligand family, ODF/OPGL/TRANCE/RANKL, regulates osteoclast differentiation and function. Biochemical and biophysical research communications. 1999;256(3):44955.

126. Peters OA. Research that matters - biocompatibility and cytotoxicity screening. International endodontic journal. 2013;46(3):195-7.

127. van't Hof RJ, Ralston $\mathrm{SH}$. Nitric oxide and bone. Immunology. 2001;103(3):255-61.

128. Dong SS, Williams JP, Jordan SE, Cornwell T, Blair HC. Nitric oxide regulation of cGMP production in osteoclasts. Journal of cellular biochemistry. 1999;73(4):47887.

129. Wang FS, Wang CJ, Chen YJ, Huang YT, Huang HC, Chang PR, et al. Nitric oxide donor increases osteoprotegerin production and osteoclastogenesis inhibitory 
activity in bone marrow stromal cells from ovariectomized rats. Endocrinology. 2004;145(5):2148-56.

130. Hayman AR, Macary P, Lehner PJ, Cox TM. Tartrate-resistant acid phosphatase (Acp 5): identification in diverse human tissues and dendritic cells. The journal of histochemistry and cytochemistry : official journal of the Histochemistry Society. 2001;49(6):675-84.

131. Lee IH, Zhao C, Cho Y, Harwig SS, Cooper EL, Lehrer RI. Clavanins, alphahelical antimicrobial peptides from tunicate hemocytes. FEBS letters. 1997;400(2):158-62.

132. Modena KC, Casas-Apayco LC, Atta MT, Costa CA, Hebling J, Sipert CR, et al. Cytotoxicity and biocompatibility of direct and indirect pulp capping materials. Journal of applied oral science : revista FOB. 2009;17(6):544-54.

133. Zhang C, Tang TT, Ren WP, Zhang XL, Dai KR. Inhibiting wear particlesinduced osteolysis with doxycycline. Acta pharmacologica Sinica. 2007;28(10):160310.

134. Franco GC, Kajiya M, Nakanishi T, Ohta K, Rosalen PL, Groppo FC, et al. Inhibition of matrix metalloproteinase-9 activity by doxycycline ameliorates RANK ligand-induced osteoclast differentiation in vitro and in vivo. Experimental cell research. 2011;317(10):1454-64.

135. Kinugawa $S$, Koide $M$, Kobayashi $Y$, Mizoguchi $T$, Ninomiya $T$, Muto A, et al. Tetracyclines convert the osteoclastic-differentiation pathway of progenitor cells to produce dendritic cell-like cells. Journal of immunology. 2012;188(4):1772-81. 


\section{ANEXOS}

Anexo 1: Espectros obtidos por MALDI-TOF, dos peptídeos de defesa do hospedeiro Clavanina A, Clananina MO e LL-37.

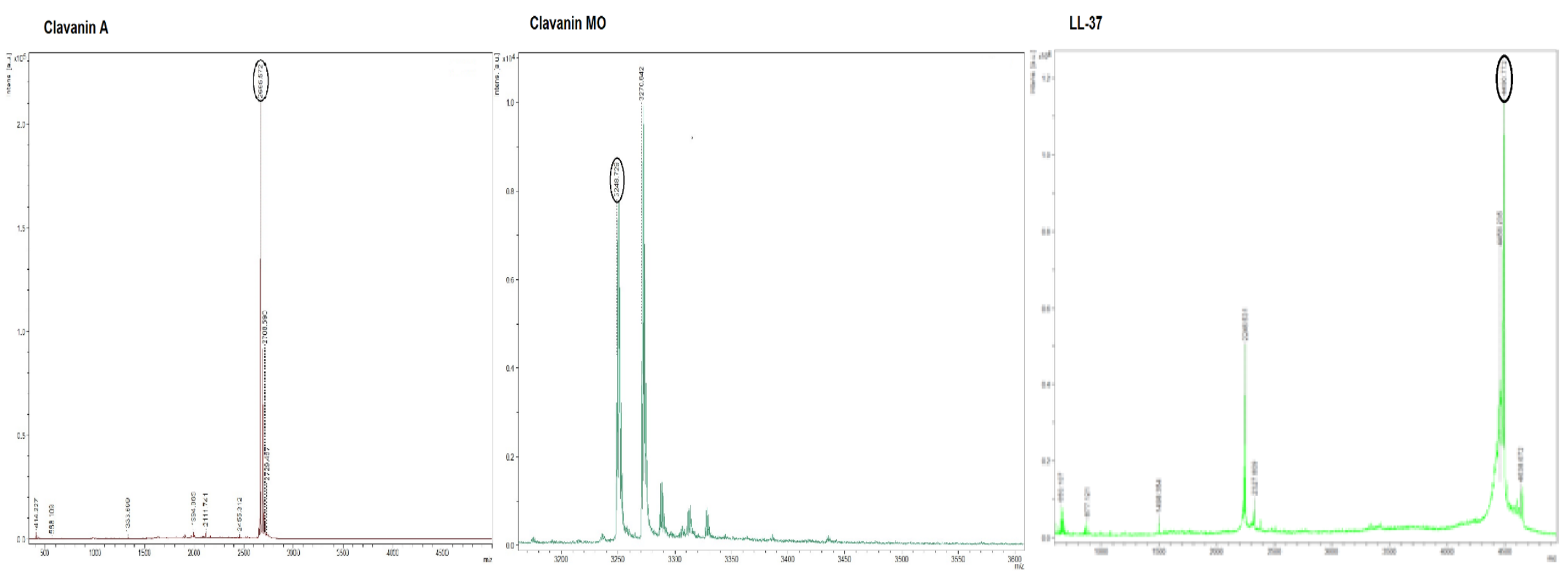

